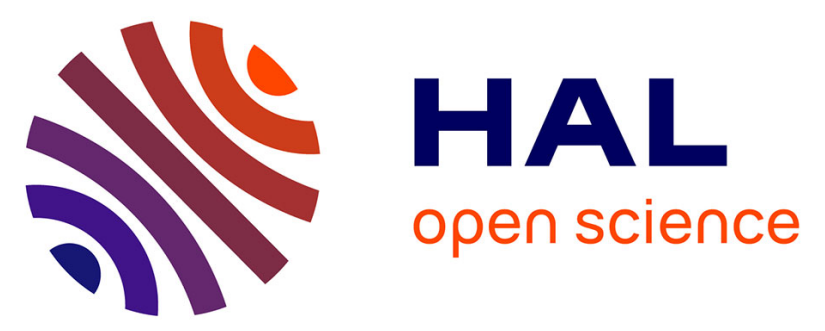

\title{
Contrasting Mesozoic evolution across the boundary between on and off craton regions of the South African plateau inferred from apatite fission track and (U-Th-Sm)/He thermochronology
}

Mark M Wildman, Roderick Brown, Cristina Persano, Romain M Beucher, Finlay M Stuart, Vhairi M Mackintosh, Kerry Gallagher, James Schwanethal, Andrew Carter

\section{- To cite this version:}

Mark M Wildman, Roderick Brown, Cristina Persano, Romain M Beucher, Finlay M Stuart, et al.. Contrasting Mesozoic evolution across the boundary between on and off craton regions of the South African plateau inferred from apatite fission track and (U-Th-Sm)/He thermochronology. Journal of Geophysical Research: Solid Earth, 2017, 122 (2), pp.1517-1547. 10.1002/2016JB013478 . insu01477149

HAL Id: insu-01477149

https://hal-insu.archives-ouvertes.fr/insu-01477149

Submitted on 27 Feb 2017

HAL is a multi-disciplinary open access archive for the deposit and dissemination of scientific research documents, whether they are published or not. The documents may come from teaching and research institutions in France or abroad, or from public or private research centers.
L'archive ouverte pluridisciplinaire HAL, est destinée au dépôt et à la diffusion de documents scientifiques de niveau recherche, publiés ou non, émanant des établissements d'enseignement et de recherche français ou étrangers, des laboratoires publics ou privés. 


\section{Journal of Geophysical Research: Solid Earth}

\section{RESEARCH ARTICLE \\ 10.1002/2016JB013478 \\ Key Points: \\ - New AFT and AHe data reveal contrasts in the thermal history of on- and off-craton regions during the \\ Contrasting Mesozoic evolution across the boundary between on and off craton regions of the South African plateau inferred from apatite fission track and (U-Th-Sm)/He thermochronology} Mesozoic

- Interior craton has stayed at less than 60 degrees Celsius since $300 \mathrm{Ma}$; off-craton experienced two discrete episodes of cooling during the Cretaceous

- Late Cretaceous denudation focused along basement structures at the craton margin and is linked to the erosion of uplifted fault blocks

Supporting Information:

- Supporting Information S1

Correspondence to:

M. Wildman,

mark.wildman@univ-rennes1.fr

\section{Citation:}

Wildman, M., R. Brown, C. Persano, R. Beucher, F. M. Stuart, V. Mackintosh, K. Gallagher, J. Schwanethal, and A. Carter (2017), Contrasting Mesozoic evolution across the boundary between on and off craton regions of the South African plateau inferred from apatite fission track and (U-Th-Sm)/He thermochronology, J. Geophys. Res. Solid Earth, 122, doi:10.1002/2016JB013478.

Received 22 AUG 2016

Accepted 2 FEB 2017

Accepted article online 3 FEB 2017

C2017. American Geophysical Union. All Rights Reserved.

\author{
Mark Wildman $^{1,2} \mathbb{D}^{\mathrm{D}}$, Roderick Brown ${ }^{1} \mathrm{D}$, Cristina Persano ${ }^{1}$, Romain Beucher ${ }^{1,3}$, Finlay M. Stuart ${ }^{4}$, \\ Vhairi Mackintosh $^{5}$ (D), Kerry Gallagher ${ }^{6}$ (D) James Schwanethal ${ }^{7}$, and Andrew Carter ${ }^{8}$ (D) \\ ${ }^{1}$ School of Geographical and Earth Sciences, College of Science and Engineering, University of Glasgow, Glasgow, Scotland, \\ ${ }^{2}$ Now at Géosciences Rennes, Université de Rennes, Rennes, France, ${ }^{3}$ Now at School of Earth Sciences, University of \\ Melbourne, Melbourne, Victoria, Australia, ${ }^{4}$ Scottish Universities Environmental Research Centre, East Kilbride, Scotland, \\ ${ }^{5}$ School of Earth Sciences, University of Melbourne, Melbourne, Victoria, Australia, ${ }^{6}$ Géosciences Rennes, Université de \\ Rennes, Rennes, France, ${ }^{7}$ Department of Earth Sciences, University College London, London, UK, ${ }^{8}$ Department of Earth and \\ Planetary Sciences, Birkbeck, University of London, UK
}

Abstract The timing and mechanisms involved in creating the elevated, low-relief topography of the South African plateau remain unresolved. Here we constrain the thermal history of the Southwest African plateau since $300 \mathrm{Ma}$ by using apatite fission track (AFT) and (U-Th-Sm)/He (AHe) thermochronology. Archean rocks from the center of the Kaapvaal Craton yield AFT ages of $331.0 \pm 11.0$ and $379.0 \pm 23.0 \mathrm{Ma}$ and mean track lengths (MTLs) of $11.9 \pm 0.2$ and $12.5 \pm 0.3 \mu \mathrm{m}$. Toward the southwest margin of the craton and in the adjacent Paleozoic mobile belt, AFT ages are significantly younger and range from $58.9 \pm 5.9$ to $128.7 \pm 6.3 \mathrm{Ma}$ and have longer MTLs $(>13 \mu \mathrm{m})$. The range of sample AHe ages complements the AFT ages, and single-grain AHe ages for most samples are highly dispersed. Results from joint inverse modeling of these data reveal that the center of the craton has resided at near-surface temperatures $\left(<60^{\circ} \mathrm{C}\right)$ since $300 \mathrm{Ma}$, whereas the margins of the craton and the off-craton mobile belt experienced two discrete episodes of cooling during the Cretaceous. An Early Cretaceous cooling episode is ascribed to regional denudation following continental breakup. Late Cretaceous cooling occurs regionally but is locally variable and may be a result of a complex interaction between mantle-driven uplift and the tectonic setting of the craton margin. Across the entire plateau, samples are predicted to have remained at near-surface temperatures throughout the Cenozoic, suggesting minimal denudation $(<1 \mathrm{~km})$ and relative tectonic stability of the plateau.

\section{Introduction}

Elevated, low-relief interior plateaus are a defining morphological feature of high-elevation continental margins [Bishop, 2007; Blenkinsop and Moore, 2013]. They are typically considered to be tectonically inactive having experienced only limited deformation that is largely restricted to gentle, long-wavelength warping [e.g., Moore et al., 2009; Cloetingh et al., 2013]. The South African plateau is surrounded by classic high-relief escarpment zones. It is arguably the type-example of a high-elevation continental margin, yet both its mode of formation and its subsequent evolution remain controversial.

The mechanism that generated the high elevation of the plateau, and the timing of plateau formation, is at the center of the controversy [e.g., Partridge and Maud, 1987; Brown et al., 2002; Braun et al., 2014; Rudge et al., 2015; Green et al., 2016]. Insights from geodynamic models support the hypothesis that vertical stresses imposed at the base of the lithosphere by the vertical component of mantle flow will induce significant uplift (or subsidence for downwelling mantle) of the interior plateau [e.g., Gurnis et al., 2000; Moucha et al., 2008; Braun, 2010; Forte et al., 2010; Flament et al., 2014]. It is also significant that recent thermomechanical models that simulate the interaction between mantle convection and the overlying lithosphere suggest that brittle deformation of the upper crust at short-wavelength scales may also occur in tandem with longer wavelength (plume-induced) uplift of the lithosphere [e.g., Burov and Cloetingh, 2009; Guillou-Frottier et al., 2012; Cloetingh et al., 2013; Koptev et al., 2015]. In addition to deformation arising from these vertical stresses applied at the base of the lithosphere, horizontal stresses arising from plate boundary and plate kinematic changes may propagate significant distances and drive local, brittle deformation and reactivation of pre-existing 


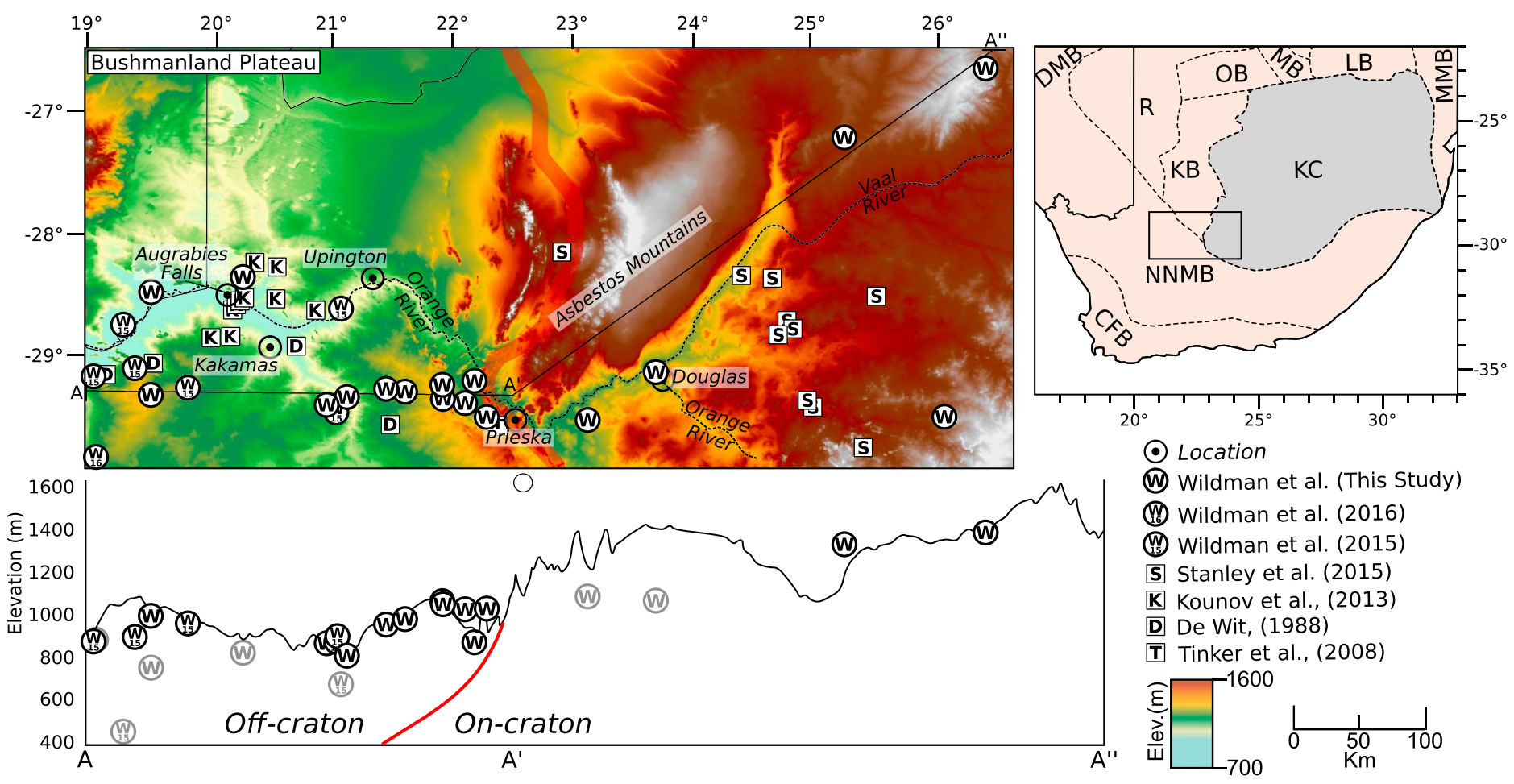

Figure 1. (top right) Location of the Bushmanland Plateau study area relative to Southern Africa. The grey shading indicates extent of the "on-craton" region, and the

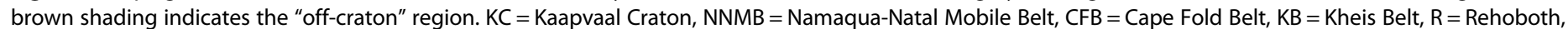
$\mathrm{DMB}=$ Damara Mobile Belt, $\mathrm{OB}=$ Okwa Block, $\mathrm{MB}=$ Magondi Belt, $\mathrm{LB}=$ Limpopo Belt, MMB = Mozambique Mobile Belt. (top left) $\mathrm{DEM}$ of Bushmanland Plateau study area created by using SRTM90m data. The red line indicates craton boundary. (bottom) Elevation profile (dog-legged) showing the location of samples from this study and from Wildman et al. [2015, 2016]. The light grey samples are those beyond a $50 \mathrm{~km}$ range either side of the section line.

structures within continental interiors [Daly et al., 1989; Janssen et al., 1995; Guiraud and Bosworth, 1997; Fairhead et al., 2013; Viola et al., 2012; Pérez-Díaz and Eagles, 2014; Salomon et al., 2014, 2015].

Continental interiors are often centered around Archean-Paleoproterozoic cratons that are surrounded by Mesoproterozoic-to-Neoproterozoic orogenic belts. In the case of Southern Africa, the Mesoproterozoic-toNeoproterozoic regions are characterized by a distinct tectonic fabric that developed during early accretion of older cratons [Jacobs et al., 1993; Karlstrom and Humphreys, 1998]. The southwest corner of the Kaapvaal Craton and its boundary with the Namaqua mobile belt represent such a tectonic setting with prominent NW-SE trending thrust faults and shear zones defining the craton boundary (Figures 1 and 2). Recent work has shown that due to thermal, compositional, and structural contrasts across the craton margin, regional stresses and/or mantle instabilities may become focused at the craton margin and induce intraplate deformation along lithospheric-scale craton boundary faults [Lenardic et al., 2000, 2003; Guillou-Frottier et al., 2012].

In this paper we present 17 new apatite fission track (AFT) and 103 single-grain apatite (U-Th-Sm)/He (AHe) analyses from the Bushmanland Plateau. Using a Bayesian transdimensional approach to thermal history inversion [Gallagher, 2012], temperature-time cooling paths are obtained for each sample. The thermal histories are used to derive magnitudes of denudation and evaluate the timing and pattern of uplift and intracontinental deformation across this region of the South African plateau. The new data indicate that at the structurally complex zone at the craton margin an equally complex spatial pattern of deep erosion characterized the Late Cretaceous, which could be explained by post-breakup deformation driving uplift and focusing denudation.

\section{Geomorphology and Geology}

\subsection{Geomorphic Setting}

The study area is located within the South African plateau and is characterized by an extensive low-relief plain where elevations range between 800 and $1000 \mathrm{~m}$ in the west and 1200 and $1400 \mathrm{~m}$ in the east 


\section{Geological Map}

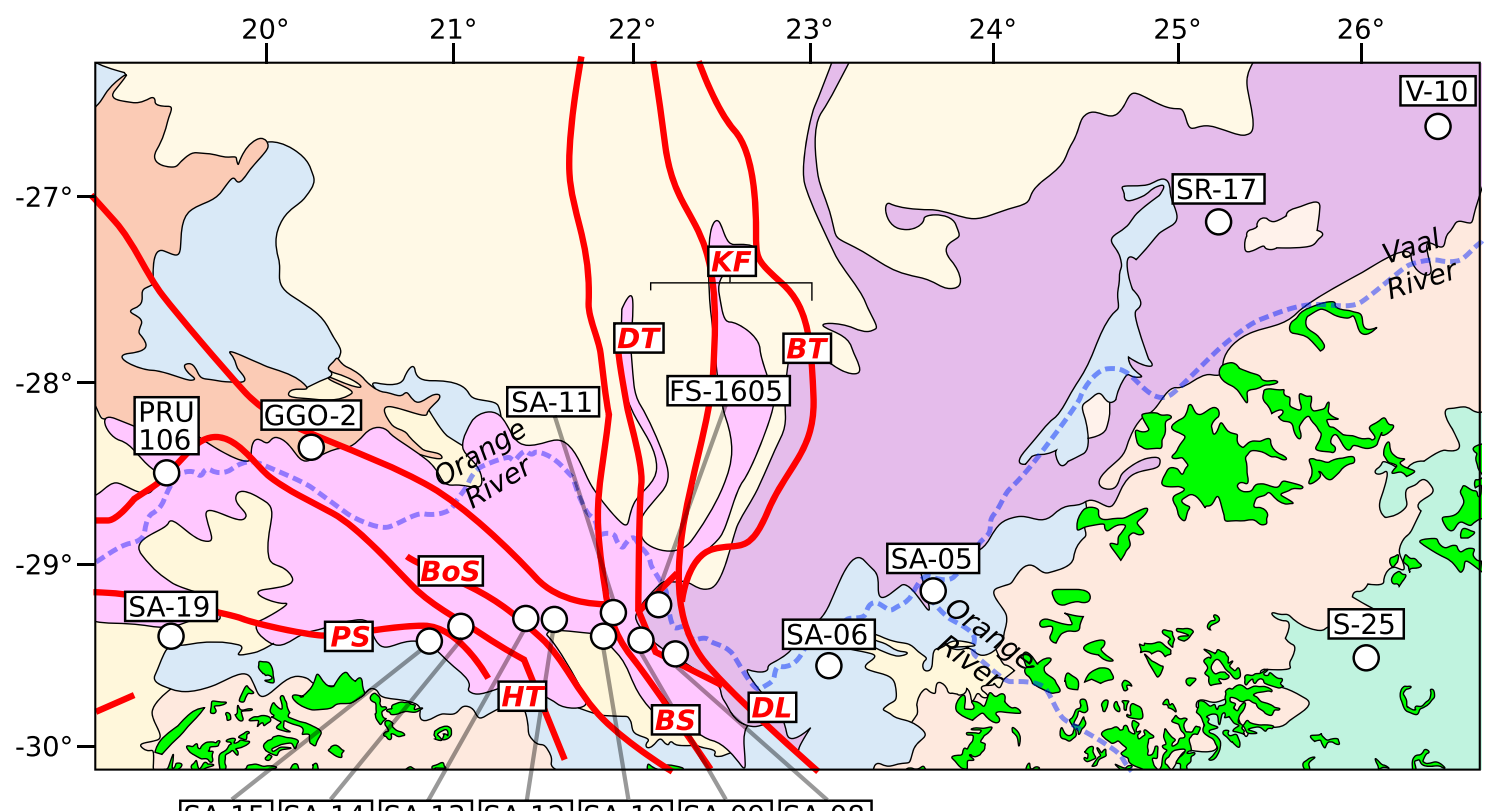

Lithological Units Cenozoic

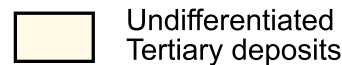

\author{
Jurassic \\ Karoo Dolerite \\ Intrusions
}

Permian - Triassic

\section{$\square$ Beaufort} Group Ecca Group Dwyka Group

Palaeozoic

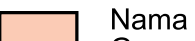
Group

Meso - Neoproterozoic

Namaqua Metamorphic Province

Archean - Palaeoproterozoic Kaapvaal Craton

\section{Schematic cross-section of major tectonic boundaries}

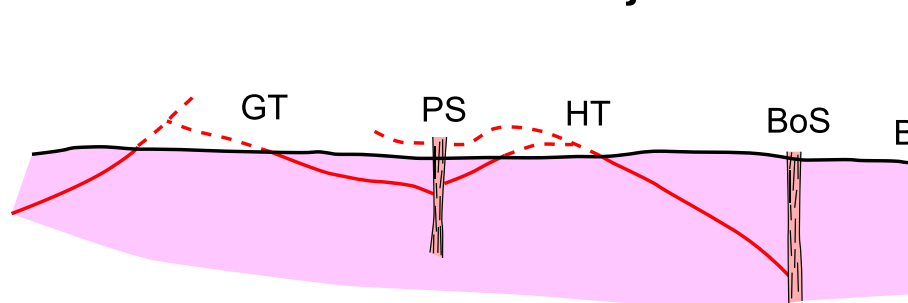

Namaqualand Metamorphic Province

Kaapvaal Craton

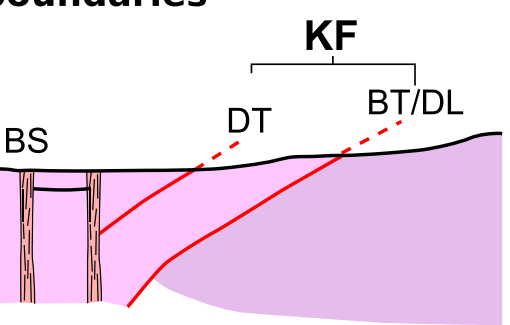

$\mathrm{KF}=$ Kheis Front BT = Blackridge Thrust DT $=$ Dabep Thrust $\mathrm{DL}=$ Doringberg Lineament BS $=$ Brakbos Shear Zone BoS = Bouzen River Shear Zone $\mathrm{HT}=$ Hartbees Thrust PS = Pofadder Shear Zone $\mathrm{GT}=$ Groothoek Thurst

Figure 2. (a) Geological map of the Bushmanland Plateau. The geological map was redrawn to highlight the major geological units, structures, and features relevant to this study, using 1:1 ×1,000,000 map produced by the Council for Geoscience, South Africa [Fourie and Cole, 1997]; (b) schematic geological cross section of the Namaqualand Metamoprhic Province after Thomas et al. [1994]. Fault names: PS = Poffader Shear Zone; HT = Hartbees Thrust; BoS = Bouzen River Shear Zone; BS = Brakbos Shear Zone; DT = Dabep Thrust are given in the figure (after Tankard et al. [2009] and Thomas et al. [1994]).

(Figure 1). In the northeast of the study area, the Asbestos Hills, which achieve elevations of up to $1600 \mathrm{~m}$, mark the transition from the rocks of the Proterozoic Namaqua mobile belt to those of the Archean Kaapvaal Craton. The plateau forms the hinterland to the divergent continental margins of Southern Africa and is separated from low elevation, moderate relief coastal plains by a prominent escarpment zone of significantly higher relief [Gilchrist et al., 1994; Brown et al., 2002; Blenkinsop and Moore, 2013].

The Orange River, the largest catchment in South Africa and responsible for draining $\sim 80 \%$ of the subcontinent, enters the study area in the southeast and exits in the west before continuing westward toward the Atlantic Ocean (Figure 1). At the town of Douglas, the northwest trending Orange River (Figure 1) converges with the southwest flowing Vaal River, which drains northeast South Africa. North of Prieska, the Orange River follows the major NW-SE structural trend of the Kheis Front and, specifically, the Doringberg Lineament, which marks the tectonic boundary between the Kaapvaal Craton and the Namaqua Belt. After continuing on this trend for $\sim 170 \mathrm{~km}$, the Orange River meanders as it flows west through the towns of Upington and Kakamas. The main Orange River channel includes several significant knickpoints along its course, 
particularly the $90 \mathrm{~m}$ Augrabies Falls [Tooth and McCarthy, 2004; Dauteuil et al., 2013; Paul et al., 2014], which is downstream to the west of the study area. The Vaal River flows within a prominent (up to $300 \mathrm{~m}$ deep) NW-SE trending valley into the Kaapvaal Craton.

The main drainage network of the Orange River has been in place from the middle-to-Late Cretaceous [Partridge and Maud, 1987; Dollar, 1998; de Wit, 1999, 2009]. Below the Augrabies Falls, the preservation of Pliocene, middle Miocene, and possibly Eocene river terraces indicates that there has been moderate channel incision of the lower Orange River through the Tertiary [de Wit, 1999; Jacob et al., 1999]. Preserved middle-to-Late Cretaceous diamond bearing and fossiliferous alluvial gravels in the upper Vaal support the antiquity of the present drainage network (Mahura Muthla channel [de Wit et al., 2009]; the Mahura Muthla channel is proposed to have fed the Kalahari paleoriver, which exited into the Atlantic at the present-day position of the lower Orange River and had captured the Upper Karoo River (composed of the present-day middle and upper Orange River and Vaal River) by the end of the Cretaceous [de Wit, 1999; de Wit et al., 2009]). The preservation of these geomorphic features, as well as similar deposits in Sundays River (southeast coast), and lacustrine deposits on Late Cretaceous intrusions in Namaqualand and Bushmanland [Cornelissen and Verwoerd, 1975; Moore and Verwoerd, 1985; Smith, 1986; Hanson et al., 2009; Stanley et al., 2013] suggests that regional erosion has been minimal through the Cenozoic. Cosmogenic nuclide dating has constrained the regional erosion rates to $<20 \mathrm{~m} / \mathrm{Myr}$ over at least the last 1 Myr [e.g., Codilean et al., 2008, 2014; Bierman et al., 2014; Decker et al., 2011; Erlanger et al., 2012; Kounov et al., 2015; Scharf et al., 2013].

\subsection{Geological and Tectonic Setting}

The Archean-Paleoproterozoic Transvaal Supergroup rocks form the basement of the Kaapvaal Craton within the study area [Altermann and Nelson, 1998; Eriksson et al., 2006]. They were deposited in a shallow marine environment prior to experiencing multiple deformation phases between 2500 and $1000 \mathrm{Ma}$ and greenschist facies metamorphism [Kendall et al., 2013]. An array of NW-SE to N-S trending, steeply dipping, en echelon faults forming the Kheis Front define the structurally complex transition from the Kaapvaal Craton to the younger Namaqua Metamorphic Province [Altermann and Hälbich, 1991; Eriksson et al., 2006] (Figure 2). These faults initially formed during the Mesoproterozoic [Eglington, 2006] and accommodated many deformation events from 2 to $1 \mathrm{Ga}$ [Altermann and Hälbich, 1991]. The NW structural trend that characterizes the southwest Kaapvaal Craton margin extends southwestward from southern Namibia and into South Africa, where post-Triassic displacement on brittle faults is indicated by the presence of fault-bounded basement inliers in contact with Karoo sediments [Rosendahl, 1987; Daly et al., 1989; Jelsma et al., 2009; Tankard et al., 2009] (Figure 2).

The entire Namaqua Metamorphic Province experienced significant metamorphism over $\sim 2000$ and $1000 \mathrm{Ma}$. The main phase of metamorphism of the Namaqua Metamorphic Province was largely granulitefacies metamorphism (T: $800-860^{\circ} \mathrm{C}$ and P: 5-6 kbar) and was completed by 1000-800 Ma [Waters, 1989; Eglington, 2006]. Lithostratigraphic variations in the Namaqua Metamorphic Province define terrane subprovinces and are discussed in more detail by Eglington [2006] and Cornell et al. [2006]. These terrane subprovinces are bounded by major shear zones and thrust belts that are evident along the Orange River that extend into southern Namibia (Figure 2).

The Hartbees River Thrust is the western most thrust fault in the study area and trends NW-SE before deviating E-W and running parallel to the Orange River [Colliston et al., 2015]. The generally E-W structural trend of the western section of the study area is best represented by the Tantalite Valley shear zone, Groothoek Thrust, and, further south, Buffels River shear zone. Within the Tantalite Valley shear zone, NNE-to-NE trending normal structures associated with transtensional stresses juxtapose basement gneisses against late Proterozoic sediments of the overlying Nama Group [Gresse and Germs, 1993; Gresse et al., 2006]. These faults were formed and accommodated multiple deformation phases over 1.3-1.0 Ga [Eglington, 2006; Dewey et al., 2006; Colliston and Schoch, 2013].

Sedimentary units of the Permo-Triassic Karoo Supergroup were deposited over much of Southern Africa in a foreland basin north of the developing Cape Fold Belt [Catuneanu et al., 2005]. In the study area, the Karoo Supergroup unconformably overlies the basement and is represented by the Lower Permian glacially derived Dwyka Group, the Upper Permian shallow marine sandstones and siltstones 
of the Ecca Group, and the Permo-Triassic fluvial sediments of the Beaufort Group (Figure 2) [Visser, 1989; Catuneanu et al., 2005; Johnson et al., 2006; Herbert and Compton, 2007; Wilson et al., 2014]. The widespread marine sediments of the Late Permian Ecca Group provide an important stratigraphic marker as they represent the last time that the continental interior of Southern Africa was unequivocally at sea level.

Intrusive dolerite dykes, sills, and sheets are ubiquitous within the Karoo Basin and commonly crop out across the study area. The intrusion of the Karoo Dolerite Suite is thought to have occurred at 180-185 Ma [Duncan et al., 1997; Jourdan et al., 2005, 2007; Moulin et al., 2011; Svensen et al., 2012]. Mafic intrusive and extrusive rocks of similar age are found across Southern Africa and are associated with continental flood basalt emplacement during continental rifting and breakup continental rifting and breakup of Eastern Gondwana [Cox, 1992; Duncan et al., 1997].

Widespread, post-Karoo, emplacement of kimberlites and alkaline intrusions occurred in two main phases at 140-120 and 100-80 Ma [e.g., Smith et al., 1994; Moore et al., 2008; Jelsma et al., 2009]. The intrusions are thought to have been preferentially emplaced along tectonic boundaries, and their occurrence is linked to in-plane plate motions [Moore et al., 2008; Jelsma et al., 2009; Torsvik et al., 2010] and a changing thermochemical structure in the underlying mantle [Bell et al., 2003; Griffin et al., 2003; Kobussen et al., 2008]. Their preservation at the surface can provide important insights into the amount of erosion since emplacement [e.g., Hanson et al., 2009; Stanley et al., 2013, 2015].

The Cenozoic Kalahari Group, a sequence of poorly sorted consolidated gravel and sand fill paleovalleys, sits on the Karoo Supergroup and older basement rocks and can reach a thickness up to $210 \mathrm{~m}$ [Thomas and Shaw, 1990] (Figure 2). However, the timing of the development of the Kalahari Basin and subsequent sediment infill remains uncertain due to the absence of direct dating of the sediments [Haddon and McCarthy, 2005].

\subsection{Evidence for Discrete Post-breakup Tectonic Activity}

Due to the lack of suitable stratigraphic information across the study area, constraining fault reactivation of major faults during the Late Mesozoic and Cenozoic is challenging. The majority of structures mapped at the $1: 1,000,000$ scale are confined to the Namaqua Metamorphic Province where they define terrane boundaries and lithological discontinuities (Figure 2). Exceptions to this are the southern extents of the Brakbos and Doringberg faults, which displace Proterozoic basement against Carboniferous-Permian Dwyka Group rocks. SW of Douglas, a fault is also mapped which displaces Archean Transvaal Supergroup rocks against Dwyka Group rocks. Post-Permian fault reactivation is therefore unrelated to terrane accretion or Pan-African Orogenic activity.

Geological evidence for Mesozoic tectonic activity in southern Namibia is found in sporadic examples of Karoo Dolerite Suite rocks with a faulted contact with Dwyka Group, Nama Group, and/or Namaqua Metamorphic Province rocks [Stollhofen et al., 1998]. Fault-dissected Karoo dolerites suggest tectonic activity less than $180 \mathrm{Ma}$ old. Two phases of extension during the Cenozoic are advocated by Mvondo et al. [2011]. N-S grabens that shape the lower Fish River Canyon are ascribed to E-W extension in the late Eocene and NE-SW grabens shaping the upper Fish River Canyon due to younger NW-SE extension in the Plio-Pleistocene [Mvondo et al., 2011]. However, there are no quantitative constraints on the age of the African surface, which is used to constrain the timing of faulting. In NW Namibia, Late Mesozoic tectonics is constrained by the preservation of Early Cretaceous Etendeka volcanic rocks in coast-parallel half grabens [Raab et al., 2002; Brown et al., 2014; Salomon et al., 2015]. These grabens are bound by NNWSSE trending normal faults, which displace Etendeka lavas against Namaqua Metamorphic Province basement [Brown et al., 2014; Salomon et al., 2015]. Further evidence is provided by syntectonic conglomerate units composed of Etendeka volcanic material that dip to the east into a westerly dipping normal fault [Ward and Martin, 1987].

These NW Namibian examples indicate that localized faulting has occurred onshore after $130 \mathrm{Ma}$. However, as with the previously described examples, no well-dated younger stratigraphic constraints are available. We have shown previously, using combined AFT and AHe analysis, that post-breakup tectonic reactivation of brittle faults occurred during the middle-to-Late Cretaceous well inland along the Namaqualand sector of Atlantic margin in South Africa [Wildman et al., 2015, 2016]. These studies lend 
Table 1. Results of Apatite Fission Track Analysis

\begin{tabular}{|c|c|c|c|c|c|c|c|c|c|c|c|c|}
\hline Sample & Long. $\left({ }^{\circ}\right)$ & Lat. $\left({ }^{\circ}\right)$ & Elev. (m) & $\rho_{s}^{\mathrm{a}}\left(10^{6} \mathrm{~cm}^{-2}\right)$ & $N_{s}{ }^{\mathrm{b}}$ & $\rho_{i}^{\mathrm{a}}\left(10^{6} \mathrm{~cm}^{-2}\right)$ & $N_{i}^{b}$ & $\rho_{d}^{\mathrm{a}}\left(10^{6} \mathrm{~cm}^{-2}\right)$ & $N_{d}^{\mathrm{b}}$ & $P\left(\chi^{2}\right)^{c}(\%)$ & $D_{\text {par }}{ }^{\mathrm{d}}(\mu \mathrm{m})$ & {$[\mathrm{U}]^{\mathrm{e}}(\mathrm{ppm})$} \\
\hline FS1605 & 22.20 & -29.22 & 843 & 5.7 & 400 & 12.1 & 845 & 16.5 & 13,142 & 99.5 & 2.07 & 10.1 \\
\hline GGO2 & 20.30 & -28.36 & 846 & 21.3 & 2174 & 68.8 & 7023 & 20.0 & 13,142 & 0.2 & 1.75 & 48.5 \\
\hline PRU 106 & 19.52 & -28.48 & 783 & 19.2 & 1092 & 82.3 & 4672 & 21.7 & 13,142 & 5.7 & 1.76 & 51.5 \\
\hline $\mathrm{S}-25$ & 26.08 & -29.52 & 1450 & 1.0 & 911 & 1.4 & 1239 & 1.0 & 4441 & 19.4 & - & 26.0 \\
\hline SA12-05 & 23.70 & -29.15 & 1007 & 4.3 & 249 & 13.5 & 777 & 16.7 & 16,348 & 45.6 & 2.02 & 11.9 \\
\hline SA12-06b & 23.14 & -29.54 & 1068 & 7.4 & 537 & 18.7 & 1362 & 15.6 & 16,348 & 3.5 & 1.97 & 16.1 \\
\hline SA12-08 & 22.31 & -29.52 & 1039 & 1.9 & 195 & 4.4 & 465 & 15.5 & 16,348 & 99.7 & 1.53 & 3.9 \\
\hline SA12-09 & 22.12 & -29.40 & 995 & 5.8 & 535 & 12.4 & 1150 & 15.4 & 16,348 & 94.0 & 2.44 & 11.3 \\
\hline SA12-10 & 21.94 & -29.36 & 1075 & 4.0 & 151 & 12.0 & 449 & 16.6 & 16,438 & 22.1 & 1.77 & 9.2 \\
\hline SA12-11 & 21.94 & -29.24 & 1057 & 2.2 & 122 & 9.4 & 526 & 16.1 & 16,348 & 62.7 & 4.96 & 7.7 \\
\hline SA12-12 & 21.63 & -29.30 & 981 & 10.3 & 930 & 29.1 & 2631 & 15.2 & 16,348 & 12.7 & 2.38 & 25.1 \\
\hline SA12-13a & 21.47 & -29.28 & 962 & 9.1 & 787 & 25.3 & 2190 & 15.1 & 16,348 & 7.8 & 2.44 & 22.3 \\
\hline SA12-14 & 21.15 & -29.35 & 797 & 6.2 & 1013 & 15.5 & 2553 & 14.9 & 16,348 & 0.0 & 2.87 & 13.9 \\
\hline SA12-15 & 20.98 & -29.42 & 884 & 5.7 & 305 & 23.1 & 1237 & 16.6 & 16,348 & 50.2 & 1.69 & 19.5 \\
\hline SA12-19b & 19.53 & -29.34 & 1034 & 7.7 & 994 & 16.9 & 2183 & 13.8 & 16,086 & 9.9 & 1.63 & 17.2 \\
\hline SR-17 & 25.25 & -27.13 & 1300 & 2.2 & 2637 & 1.2 & 1553 & 1.1 & 5540 & 38.7 & & 14.9 \\
\hline V-10 & 26.42 & -26.63 & 1400 & 0.4 & 1300 & 0.4 & 655 & 1.2 & 5540 & 9.7 & & 4.8 \\
\hline
\end{tabular}

${ }^{\mathrm{a}} \rho_{\mathrm{i}, \mathrm{s}, \mathrm{d}}$ are track density of induced, spontaneous, dosimeter tracks.

${ }^{\mathrm{b}} \mathrm{N}_{\mathrm{i}, \mathrm{s}, \mathrm{d}}$ are the number of induced, spontaneous, and dosimeter tracks counted.

${ }^{c} p$ value of the chi-square age homogeneity test [Galbraith, 2010].

${ }^{\mathrm{d}} D_{\text {par }}$ measurements are etch pit diameters used as a proxy for the influence of chemical composition on track annealing [Donelick et al., 2005]. Between three and five $D_{\text {par }}$ measurements were measured for each dated single grain.

Uranium content estimated by using EDM.

${ }^{f}$ Central AFT ages calculated with TrackKey [Dunkl, 2002] with $1 \sigma$ standard error. Ages were calculated by using a $\zeta=316.7 \pm 10.5$ (317.3 \pm 11.1 for samples PRU106, FS1605, and GGO2) for a standard IRMM540 glass.

${ }^{9}$ Dispersion is the standard deviation of the true single-grain ages as a percentage of their central age [Galbraith, 2010].

$\mathrm{h}_{\mathrm{SD}}$ is the standard deviation of measured horizontal confined track lengths.

i'Mean track lengths after individual track length measurements are corrected for their orientation to the $c$ axis after Ketcham [2005].

${ }^{\mathrm{j}}$ Number of measured horizontal confined tracks (HCTs). Analytical details can be found in Text S1. Details on sample lithology can be found Table S7.

further support to earlier thermochronology [Gallagher and Brown, 1997; Kounov et al., 2009] and structural investigations [Viola et al., 2012] that advocate significant post-rift tectonic activity in the Namaqualand region. Seismic activity indicates that the tectonic boundary between the Kaapvaal Craton and Namaqua Metamorphic Province mobile belt remains active [Tankard et al., 2009]. Post-rift tectonic activity is well documented for the offshore margin. Seismic reflection data from the Orange, Luderitz, and Walvis Basins, adjacent to the South African and Namibian continental margins, clearly indicate regional deformation in the Upper Cretaceous sequences and segmentation of the margin by faults, which can be traced onshore [Dingle et al., 1983; Clemson et al., 1997; Viola et al., 2005; de Vera et al., 2010].

\section{Apatite Fission Track and (U-Th-Sm)/He Analysis}

In apatite, annealing of damage trails from the spontaneous fission of $U$ and retention of He from the alpha decay of $\mathrm{U}, \mathrm{Th}$, and $\mathrm{Sm}$ as the crystal cools through temperatures of 120 to $40^{\circ} \mathrm{C}$ in the upper crust enable apatite fission track and apatite (U-Th-Sm)/He analysis to constrain denudation-driven exhumation over million year timescales [Lisker et al., 2009].

Spontaneous fission tracks form in apatite with an initial etchable length of $\sim 16 \pm 1 \mu \mathrm{m}$ [Green et al., 1986]. Fission tracks anneal primarily as a function of temperature such that, at temperatures hotter than 110 $\pm 10^{\circ} \mathrm{C}$, tracks are entirely annealed and temperatures cooler than $60^{\circ} \mathrm{C}$ track annealing is minimal [Green et al., 1985]. The intervening temperature range is termed as the partial annealing zone where annealing rate is inversely proportional to temperature [Gleadow and Fitzgerald, 1987]. Apatite composition (particularly F, $\mathrm{Cl}$, and $\mathrm{OH}$ substitution) can also influence the annealing rate of tracks [Carlson et al., 1999]. By measuring the spontaneous track density of ${ }^{238} \mathrm{U}$ in a sample relative to the induced track density of ${ }^{235} \mathrm{U}$ in a mica external detector, a fission track age can be obtained. Age data can be combined with length measurements of 
Table 1. (continued)

\begin{tabular}{|c|c|c|c|c|c|c|c|c|c|c|c|}
\hline \multirow[b]{2}{*}{ Sample } & \multirow[b]{2}{*}{ C. AFT Age $(\mathrm{Ma})^{\mathrm{f}}$} & \multirow[b]{2}{*}{ $\pm 1 \sigma$} & \multirow[b]{2}{*}{ Disp. $^{9}(\%)$} & \multirow[b]{2}{*}{ \#Xtls } & \multicolumn{3}{|c|}{ Measured } & \multicolumn{3}{|c|}{ c Axis Correction ${ }^{i}$} & \multirow[b]{2}{*}{$\# \mathrm{HCT}^{\mathrm{j}}$} \\
\hline & & & & & MTL $(\mu \mathrm{m})$ & $\pm 1 \sigma$ & $S D^{h}$ & MTL $(\mu \mathrm{m})$ & $\pm 1 \sigma$ & $S D^{h}$ & \\
\hline FS1605 & 122.8 & 7.5 & 0 & 20 & 12.87 & 0.25 & 2.00 & 14.38 & 0.28 & 1.35 & 63 \\
\hline GGO2 & 96.6 & 3.6 & 12 & 20 & 12.89 & 0.15 & 1.55 & 13.98 & 0.16 & 1.12 & 100 \\
\hline PRU 106 & 78.1 & 3.4 & 14 & 19 & 10.33 & 0.24 & 2.19 & 12.83 & 0.30 & 1.17 & 80 \\
\hline $\mathrm{S}-25$ & 128.7 & 6.3 & 8 & 20 & 13.32 & 0.25 & 1.98 & & & & 64 \\
\hline SA12-05 & 83.9 & 6.7 & 13 & 20 & 13.37 & 0.51 & 2.10 & 14.59 & 0.56 & 1.44 & 17 \\
\hline SA12-06b & 97.7 & 6.5 & 18 & 18 & 13.43 & 0.12 & 1.26 & 14.65 & 0.13 & 0.85 & 51 \\
\hline SA12-08 & 102.1 & 8.7 & 0 & 20 & 13.32 & 0.30 & 1.85 & 14.68 & 0.33 & 0.96 & 39 \\
\hline SA12-09 & 112.5 & 5.9 & 0 & 22 & 13.98 & 0.19 & 1.44 & 15.03 & 0.20 & 0.92 & 57 \\
\hline SA12-10 & 89.0 & 10.0 & 21 & 12 & 13.98 & 0.54 & 1.61 & 15.03 & 0.58 & 1.09 & 9 \\
\hline SA12-11 & 58.9 & 5.9 & 0 & 16 & 13.25 & 0.47 & 1.83 & 14.29 & 0.51 & 1.23 & 15 \\
\hline SA12-12 & 85.4 & 3.8 & 10 & 22 & 13.84 & 0.14 & 1.23 & 14.86 & 0.15 & 0.91 & 78 \\
\hline SA12-13a & 85.7 & 4.4 & 12 & 20 & 14.29 & 0.12 & 1.17 & 15.23 & 0.13 & 0.77 & 89 \\
\hline SA12-14 & 93.4 & 5.5 & 20 & 20 & 13.28 & 0.19 & 1.33 & 14.52 & 0.21 & 0.94 & 81 \\
\hline SA12-15 & 64.5 & 4.1 & 0 & 22 & 13.52 & 0.34 & 1.38 & 14.39 & 0.36 & 1.03 & 17 \\
\hline SA12-19b & 97.0 & 4.6 & 12 & 21 & 13.55 & 0.15 & 1.38 & 14.74 & 0.16 & 0.89 & 126 \\
\hline SR-17 & 331.0 & 11 & 2 & 20 & 11.92 & 0.19 & 1.91 & & & & 100 \\
\hline V-10 & 379.0 & 23 & 14 & 20 & 12.48 & 0.25 & 1.55 & & & & 39 \\
\hline
\end{tabular}

horizontal tracks beneath the polished surface to reveal information on both the timing and rate of sample cooling [Gallagher et al., 1998].

Defining a nominal closure temperature for the apatite (U-Th-Sm)/He dating system has proven to be challenging [Fitzgerald et al., 2006]. Depending on the size of the apatite crystal (i.e., the diffusion domain) and the amount of accumulated radiation damage, the temperature range between total retention of helium and complete diffusive loss of helium can vary from 40 to $120^{\circ} \mathrm{C}$ [Gautheron et al., 2013]. Depending on the cooling history through this partial retention zone, variations in closure temperature can result in intrasample single-grain AHe ages being significantly dispersed [Brown et al., 2013]. To understand the controls on $\mathrm{AHe}$ age dispersion and the information this can yield on the thermal history of the sample, multiple single-grain aliquots are typically measured.

\subsection{Apatite Fission Track Analysis}

The external detector method [e.g., Hurford and Green, 1982; Green et al., 1989; Donelick et al., 2005] (Text S1 in the supporting information) was used to obtain AFT data from 17 samples collected across the Southwest Africa plateau (Table 1). The main transect extends west from Douglas to Pofadder cutting across and beyond the major NW-SE trending structures (e.g., Doringberg and Hartbees thrust faults). Central AFT ages range from $58.9 \pm 5.9$ to $379.0 \pm 23.0$ Ma with more than half of the sample ages being Late Cretaceous (i.e., 110-70 Ma). Mean track lengths (MTLs) within samples range from $10.33 \pm 0.24$ to $14.29 \pm 0.12 \mu \mathrm{m}$ with the standard deviation of track length measurements ranging from 1.17 to 2.19 (see Figure S2 for TLDs).

The 17 samples analyzed across the study area provided a good number of grains suitable for AFT dating ( $n>17$ for 15 samples), each with moderate-to-high track density. Radial plots for all 17 samples can be found in Figure S3 and highlight the dispersion on single-grain ages. Three samples (GGO2, SA12-06, and SA12-14) fail the chi-square homogeneity test (i.e., $P\left(\chi^{2}\right)<0.05$ ); however, single-grain age dispersion for these samples is $\leq 20 \%$ and is therefore not considered to be significantly overdispersed. To robustly interpret the significance of the AFT age in terms of the samples' thermal history, the track length distribution, compositional kinetic parameters for the sample must also be taken into account.

The relationship between AFT ages and MTLs plotted in Figure 3 clearly shows that Cretaceous ages are associated with relatively long mean track lengths (i.e., $>13 \mu \mathrm{m})$ and older ages $(>300 \mathrm{Ma})$ associated with shorter MTLs. Although relatively few data points record old AFT ages, the data set implies that 


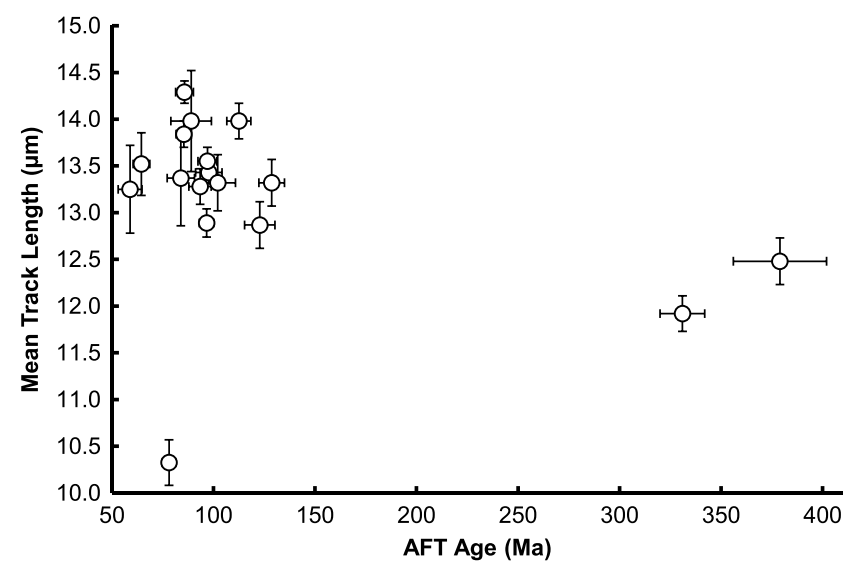

Figure 3. Plot of AFT age against mean track length. AFT ages are Central AFT ages with $1 \sigma$ standard error. MTLs are corrected for their $c$ axis orientation after Ketcham [2005] and also plotted with $1 \sigma$ standard error.
Paleozoic thermal history information has been preserved by some samples but in most cases has been entirely erased by annealing at high paleotemperatures prior to cooling in the Mesozoic.

AFT age-MTL relationships may also be influenced by variations in track annealing caused by differences in apatite composition [Kohn et al., 2009]. $D_{\text {par }}$ measurements were made for each sample as a proxy for the compositional influence on track annealing and range from $1.53 \pm 0.2$ to $4.96 \pm 0.7 \mu \mathrm{m}$. Anisotropic annealing and etching of tracks are addressed by measuring the angle that horizontal track lengths make with the $c$ axis of the analyzed grain. The influence these effects have on the fission track age and length data is taken into account during thermal history modeling (see section 4). Track length distributions are typically symmetrical or, in rare cases, negatively skewed. The majority of mean track length standard deviation values are less than 2 , which is indicative of most samples having fairly narrow to moderately broad track length distributions.

\subsection{Apatite (U-Th-Sm)/He Analysis}

Twelve samples were dated by using single-grain apatite (U-Th-Sm)/He analysis (Table 2$)$. The analytical details can be found in Text S1. The number of single grains analyzed for each sample ranges from 2 to 18. The interaction between alpha ejection, radiation damage effects, and He diffusion remains poorly understood, and depending on the thermal history, which is not known from the outset, a single $F_{t}$ correction factor may overcorrect $\mathrm{AHe}$ ages that have lost He predominantly through diffusion [Farley et al., 1996; Meesters and Dunai, 2002a, 2002b; Herman et al., 2007; Spiegel et al., 2009; Gautheron et al., 2012; Wildman et al., 2015]. For this reason, we have chosen to quote raw uncorrected, AHe ages and deal with the effect of alpha ejection during each time step of the thermal history inversion modeling approach [e.g., Meesters and Dunai, 2002a, 2002b]. AHe ages corrected by using an $F_{t}$ correction factor [Farley et al., 1996] are given in Table 2. Mean uncorrected AHe ages for Dwyka Group and Paleozoic samples range from $25.5 \pm 14.6$ to $173.7 \pm 95.9 \mathrm{Ma}$. The oldest single-grain age of $333.2 \pm 37.7 \mathrm{Ma}$ is obtained from sample FS1605, while the youngest of $16.6 \pm 1.8 \mathrm{Ma}$ is from SA12-11. The two Archean craton samples $\mathrm{V}-10$ and SR-17 have mean AHe ages of $331.0 \pm 112.8$ and $319.0 \pm 128.2$, respectively. The intrasample grain age dispersion associated with these samples is large ranging between $19 \%$ and $55 \%$.

AHe ages are subject to variation due to the thermal history the sample has experienced. However, the eU content (as a proxy for radiation damage), grain size, and crystal fragmentation act to compound and enhance single-grain AHe age dispersion [Reiners and Farley, 2001; Fitzgerald et al., 2006; Flowers et al., 2009; Gautheron et al., 2009; Brown et al., 2013]. Simple 2-D correlations between these properties and single-grain AHe age have been advocated as a means to qualitatively infer thermal history information [Reiners and Farley, 2001; Fitzgerald et al., 2006; Flowers et al., 2009; Gautheron et al., 2009]; however, the combined effects of these dispersion inducing factors can disrupt expected 2-D relationships (Figure 4c) [Brown et al., 2013; Beucher et al., 2013; Wildman et al., 2016]. Our data do not show any strong positive age-grain size or age-eU relationships, which can be attributed to the combined effects of eU, grain radius, and potentially other unknown factors that are contributing to single-grain AHe age dispersion and disrupting simple correlations (Figures $4 \mathrm{a}$ and $4 \mathrm{~b}$; see Figure S4 for additional plots). Despite samples exhibiting overdispersed $\mathrm{AHe}$ ages, all mean AHe ages are within $1 \sigma$ error of their corresponding central AFT age (Figure 4d). Neither AFT nor AHe sample ages can be simply interpreted at face value, so it is necessary to utilize an appropriate thermal history inversion approach that will account for both the observed data, their associated uncertainties, 


\section{AGU Journal of Geophysical Research: Solid Earth}

\begin{tabular}{|c|c|c|c|c|c|}
\hline 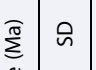 & 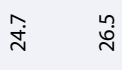 & f & ळి & $\hat{i}$ & $\overbrace{\sim}^{\infty}$ \\
\hline 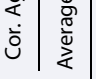 & 吕 & 品 & 宇 & 总 & 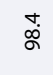 \\
\hline in & 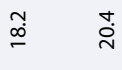 & $\stackrel{\circ}{\circ}$ & $\overline{\text { ⿵ं }}$ & $\stackrel{0}{ \pm}$ & $\stackrel{+\infty}{\infty}$ \\
\hline 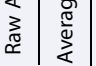 & $\overline{8}$ & $\stackrel{m}{R}$ & 吕 & 品 & $\hat{g}$ \\
\hline
\end{tabular}

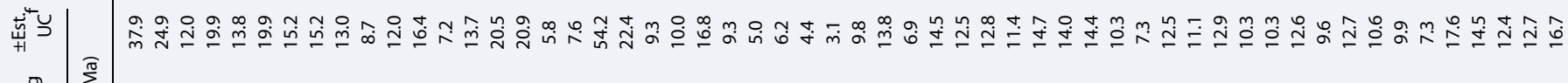

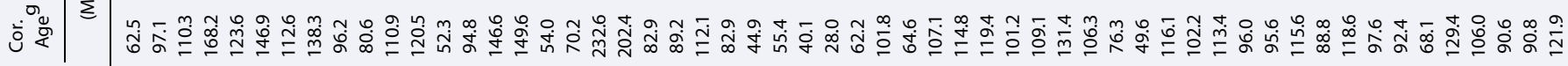

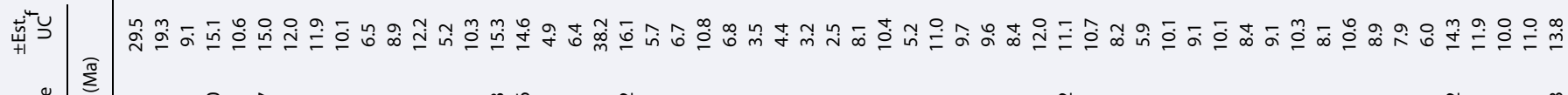
高

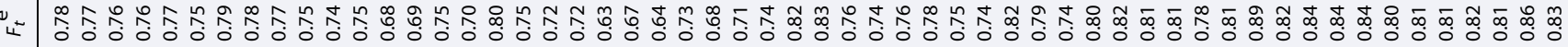

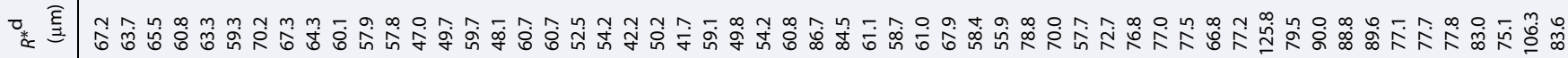

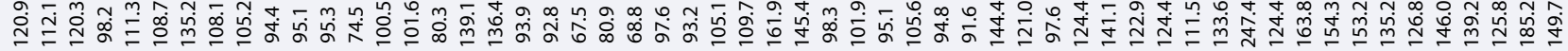

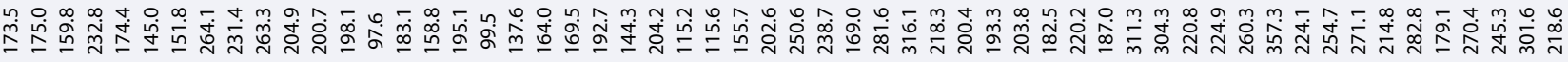

s

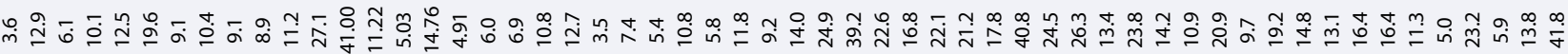

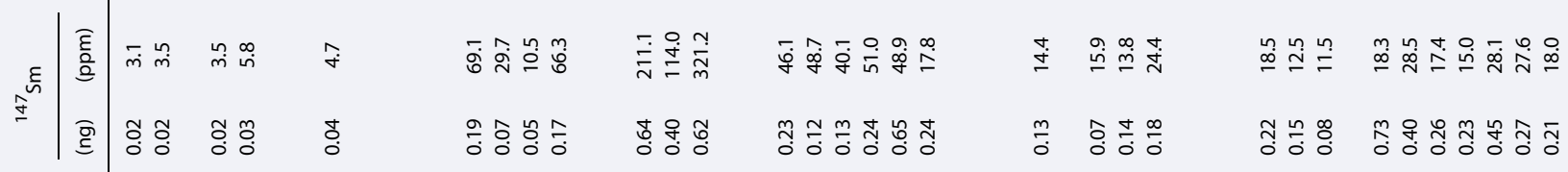

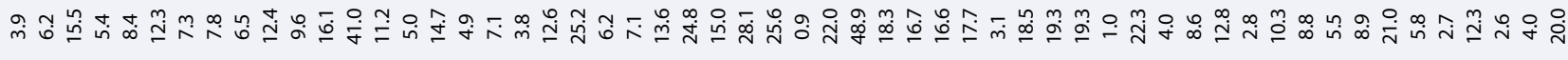

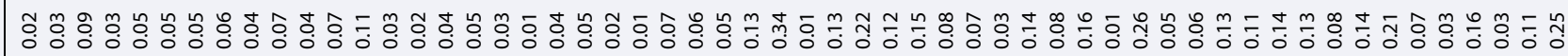

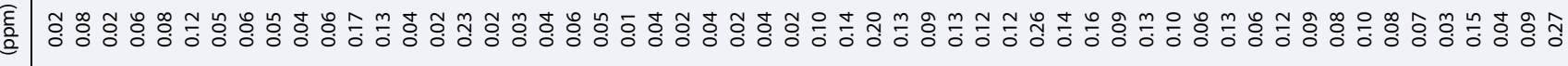

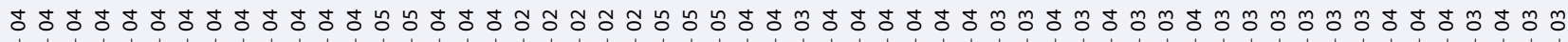

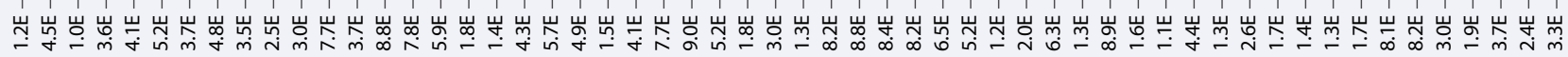

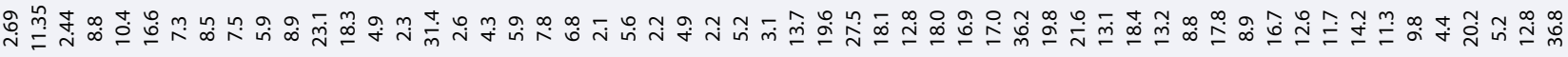

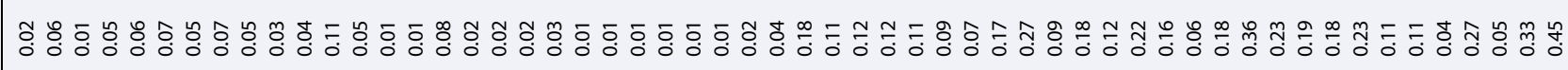

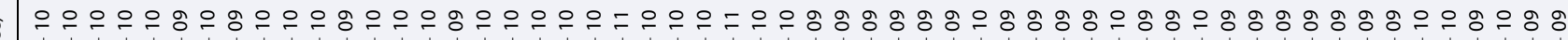

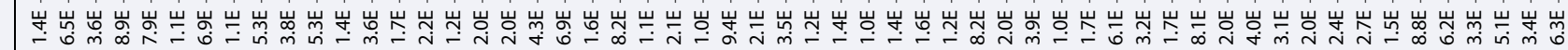

㧰
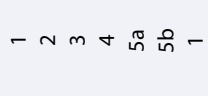

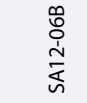

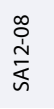

$\underset{\substack{\text { } \\ \stackrel{1}{\leftarrow}}}{\text { n }}$

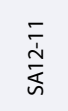

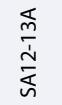

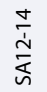




\begin{tabular}{|c|c|c|c|c|}
\hline 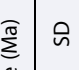 & $\stackrel{\infty}{\infty} \underset{\infty}{\infty}$ & $\tilde{\pi}$ & 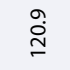 & $\bar{\sigma} \quad \stackrel{g}{g}$ \\
\hline 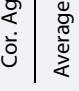 & $\stackrel{\aleph}{\stackrel{m}{m}}$ & $\stackrel{?}{\Xi}$ & $\stackrel{\infty}{\stackrel{i}{i}}$ & $\stackrel{n}{\equiv} \frac{\bar{\sigma}}{7}$ \\
\hline 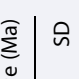 & $\stackrel{m}{0} \stackrel{n}{\sim}$ & $\stackrel{\infty}{\stackrel{\infty}{\circ}}$ & 名 & $\stackrel{\infty}{\cong}$ \\
\hline 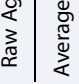 & $\underset{8}{\stackrel{m}{g}}$ & $\stackrel{\infty}{\infty}$ & $\hat{\underline{B}}$ & $\widehat{a} \stackrel{0}{\bar{m}}$ \\
\hline
\end{tabular}

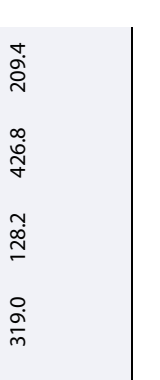

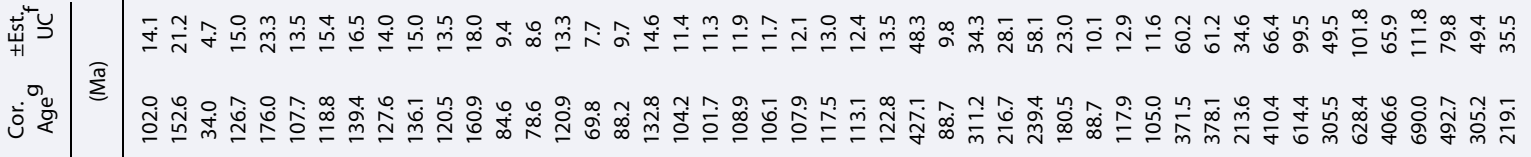

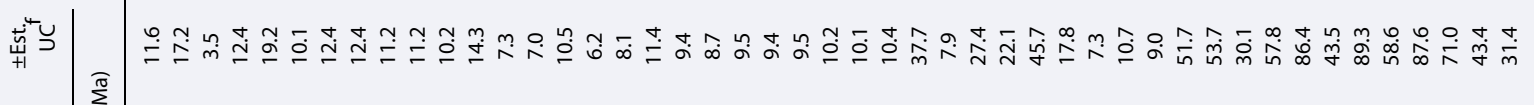
亲题

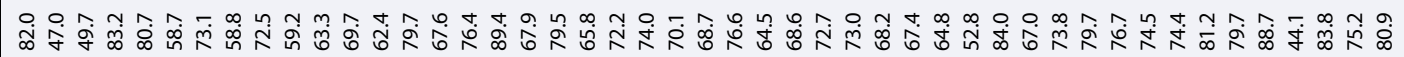

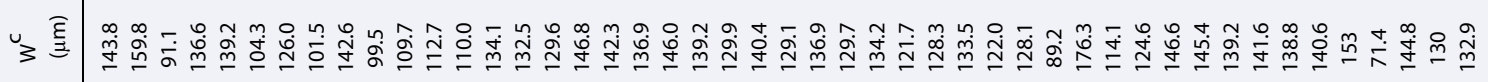

$\mathrm{u}$ 鱼

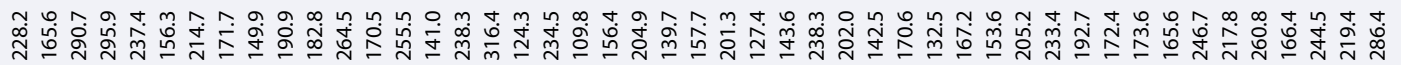
ㄴ.

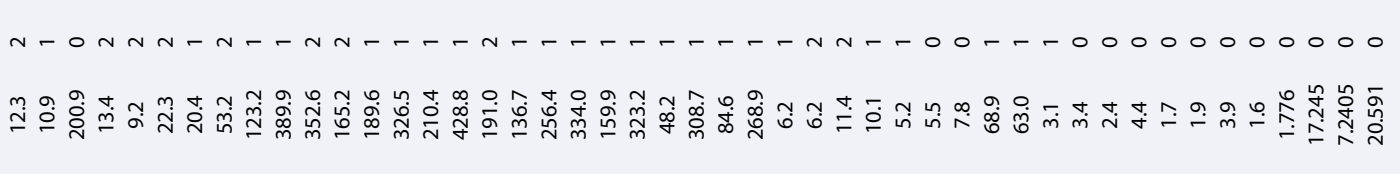

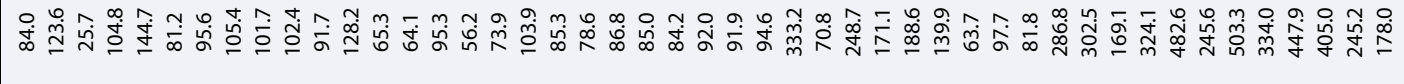

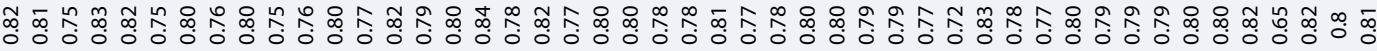

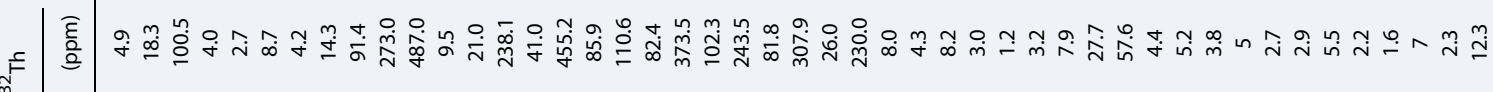

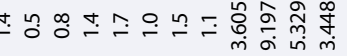

(2)

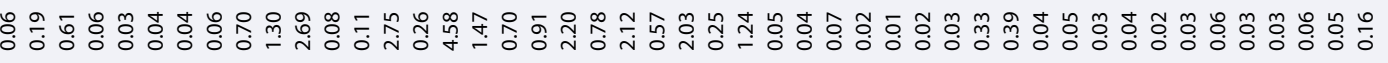

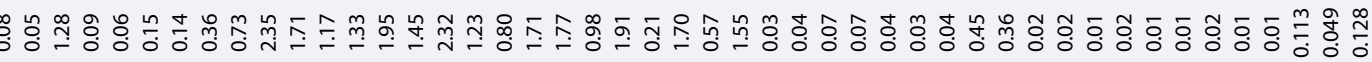

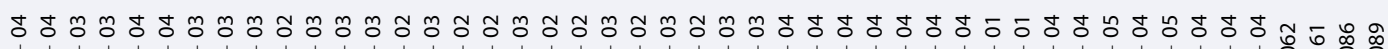

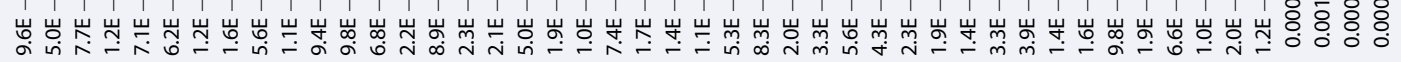

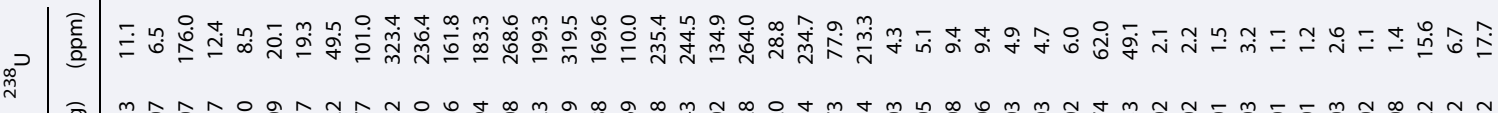

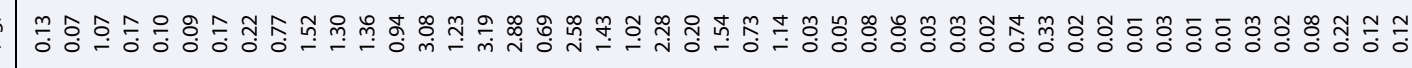

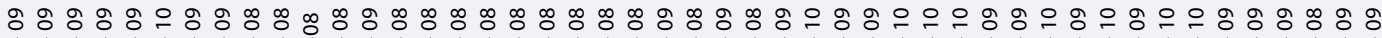
蒒

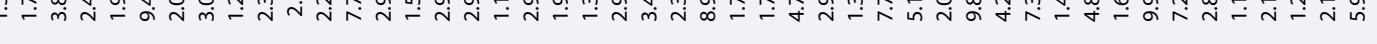
毫 in 
(a) R* vs AHe age

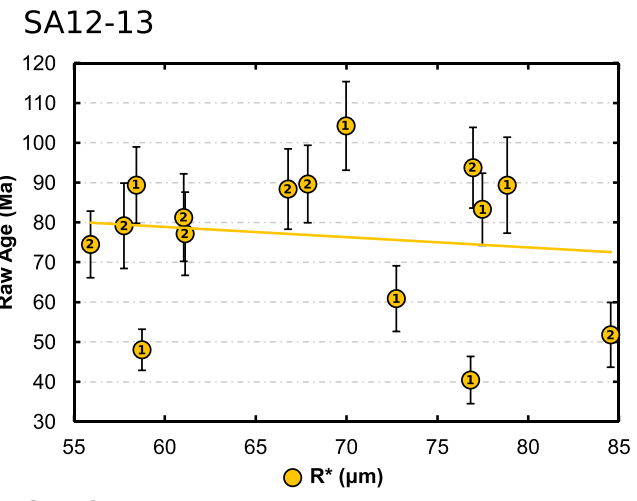

SA12-14

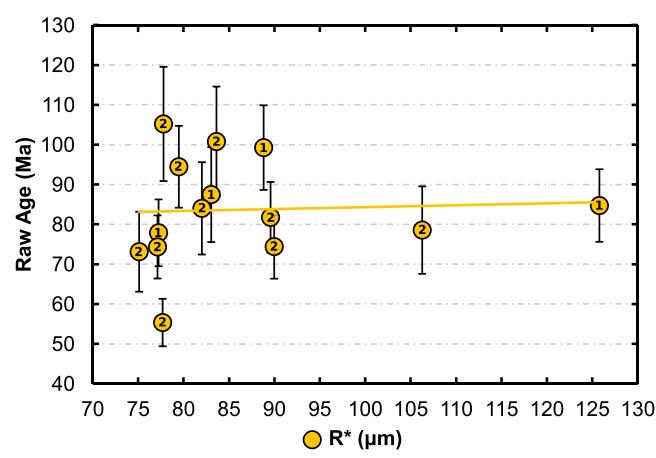

\section{GGO2}

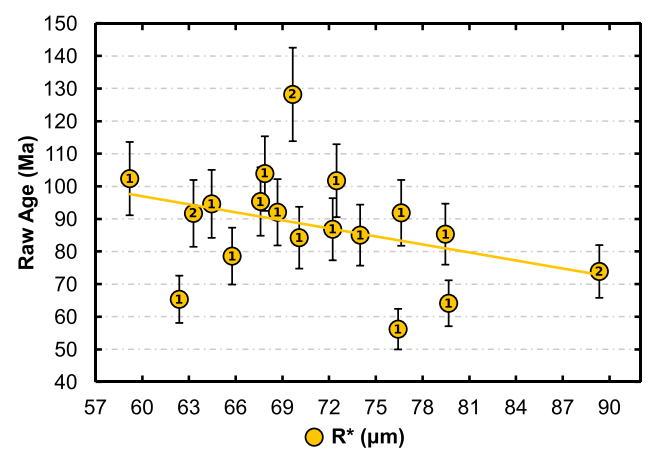

(c) Single grain age dispersion

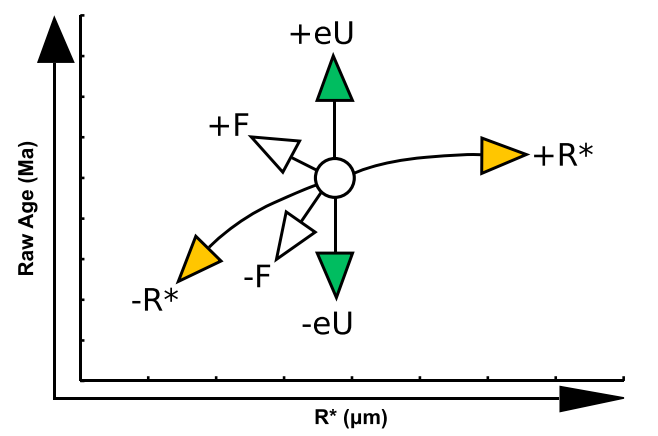

(b) eU vs AHe age

\section{SA12-13}

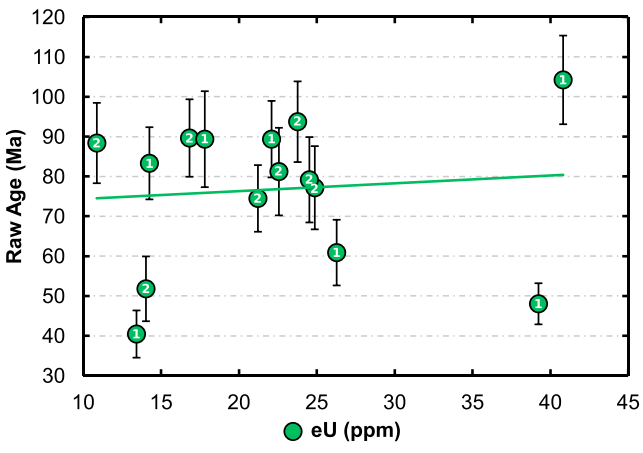

SA12-14

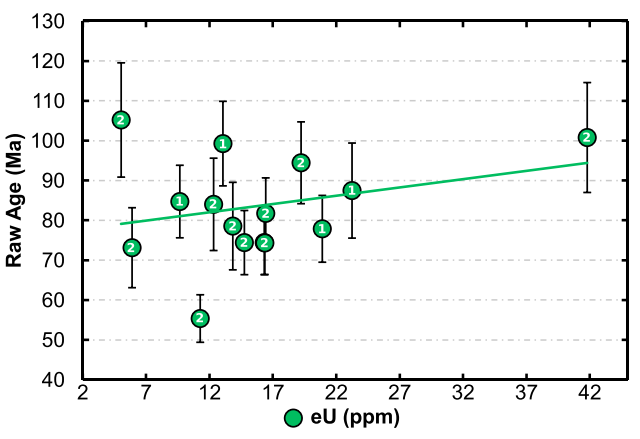

\section{GGO2}

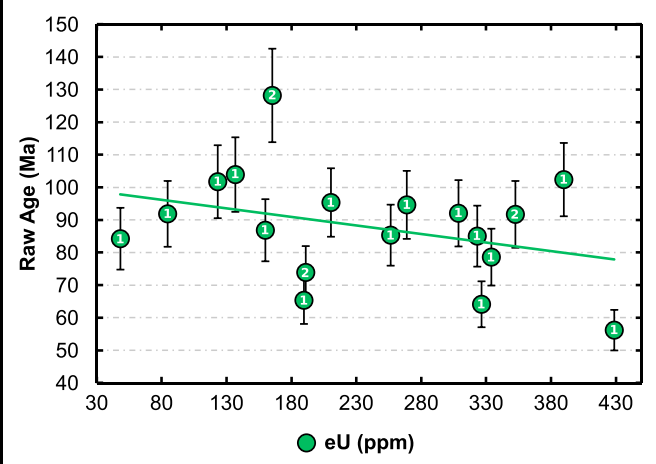

(d) Mean AHe age vs. mean AFT age

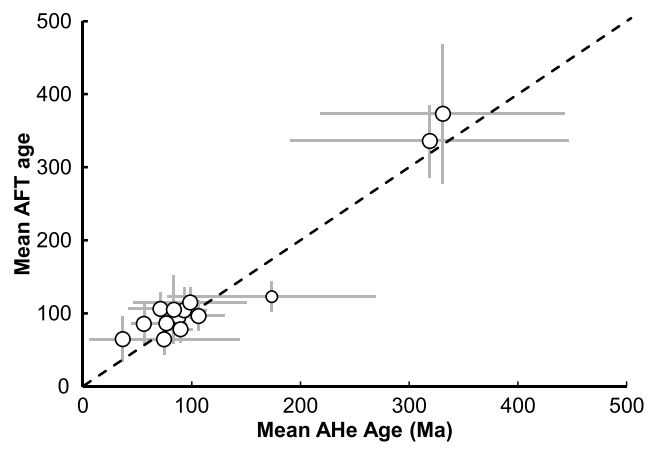

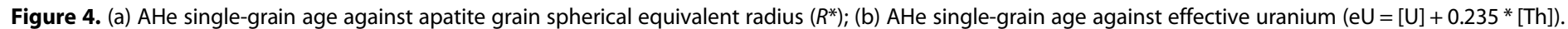

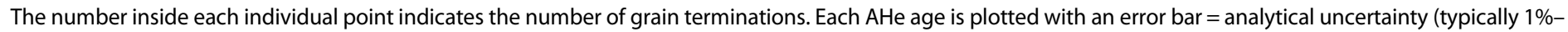

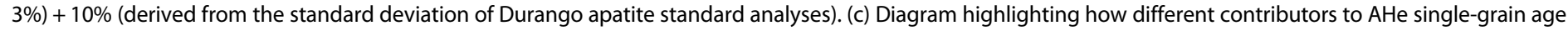

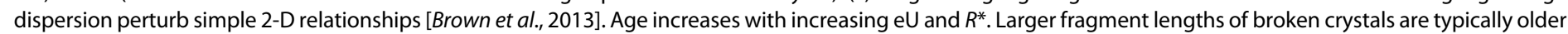
than small fragment lengths; (d) plot of mean AFT age versus mean AHe age. Additional plots of single-grain age versus eU and $R^{*}$ are given in Figure S4. 
and the uncertainties on the model parameterization itself. This is particularly important when integrating complex AFT and AHe data [Wildman et al., 2016].

\section{Thermal History Inversion}

The ultimate goal of thermochronology is to extract thermal history information and interpret this within a geological framework. Due to the complex nature of the combined AFT and AHe data sets, an appropriate inversion approach is required to extract the most probable thermal history for the observed data and the uncertainty on that data. A Bayesian approach to inverse thermal history modeling was performed by using the reversible jump Markov chain Monte Carlo (MCMC) method described by Gallagher [2012] and the software QTQt. The theoretical basis and application of this modeling technique has been well documented and discussed in previous studies [Gallagher et al., 2009; Gallagher, 2012; Cogné et al., 2011, 2012; Vermeesch and Tian, 2014; Guillaume et al., 2013; Wildman et al., 2015, 2016; Leprêtre et al., 2015]. The MCMC algorithm was run for a minimum of $\sim 200,000$ iterations after discarding an initial $\sim 50,000$ "burn in" runs [Gallagher et al., 2009; Gallagher, 2012]. However, in most cases, the number of runs far exceeds this as several short; $\sim 10,000$ iteration runs are performed in order to optimize the MCMC search parameters before performing longer runs.

For this study, the multikinetic fission track annealing model of Ketcham et al. [2007] was used and the compositional influence on fission track annealing, predominantly due to the relative proportions of $\mathrm{Cl}$ and $\mathrm{F}$ [Carlson et al., 1999; Sobel and Seward, 2010], was constrained by using a sample average $D_{\text {par }}$ value. Three samples do not have $D_{\text {par }}$ information as AFT analysis on these samples was completed prior to the common practice of measuring specific grain compositions. As such, a range in $D_{\text {par }}$ values defined as $2.04 \pm 1.50 \mu \mathrm{m}$ was used, following the same approach to similar samples reported by Wildman et al. [2015].

All AHe single-grain ages were jointly inverted alongside their corresponding AFT data by using the radiation damage accumulation and annealing model of Gautheron et al. [2009], which accounts for the effect of radiation damage accumulation and annealing on He diffusion. Ejection of alpha particles from the crystal rim [Farley et al., 1996] was accounted for during each time step of the thermal history [e.g., ,Meesters and Dunai, 2002a, 2002b]. Flowers et al. [2009] present an alternative method of modeling radiation damage accumulation and annealing on He diffusion, which has been used to derive thermal histories from many $\mathrm{AHe}$ data sets [Clark et al., 2010; Duvall et al., 2011; Ault et al., 2013; Stanley et al., 2013, 2015]. The major difference between the two radiation damage models comes from the treatment of the reduction of defects over time and temperature, which is inversely proportional to the diffusion coefficient [Flowers et al., 2009; Gautheron et al., 2009]. While the Gautheron et al. [2009] model calculates the reduction of fission track density in a linear manner, the Flowers et al. [2009] model treats it with an empirically determined cubic function and therefore predicts an enhanced reduction in diffusivity with increasing radiation damage. In practical terms, however, this will only cause significant discrepancies in predicted AHe ages for slowly cooled samples with very high $(>100 \mathrm{ppm})$ or very low eU $(<5 \mathrm{ppm})$ values. The choice of radiation damage model is therefore only a concern for two samples from our data set: GGO2 (average eU $=239 \mathrm{ppm}$ ) and V-10 (average eU = 3 ppm).

Neither model is parameterized for the effect of compositional heterogeneity on the annealing rate of damage defects [Gautheron et al., 2013; Mbongo-Djimbi et al., 2015]. As our understanding of how radiation damage accumulates and anneals and impacts helium trapping and diffusion is still developing, and as the amount of zonation [e.g., Farley et al., 2011] and implantation [e.g., Spiegel et al., 2009] in individual analyzed grains is unknown, less weight was placed on AHe ages by assigning an uncertainty to AHe single-grain ages greater than the analytical uncertainty. All AHe single-grain ages were modeled as if they were whole grain, as opposed to fragments [e.g., Brown et al., 2013; Beucher et al., 2013] and were allowed to be resampled from their uncertainty range.

\subsection{Geological Constraints}

Two samples were clasts from within the Dwyka Group glacial tillite. Sample SA12-05 was a granite dropstone, and SA12-06B was a gneissic boulder within a fine-grained, weathered matrix. An initial stratigraphic constraint of $300 \pm 10 \mathrm{Ma}, 10 \pm 10^{\circ} \mathrm{C}$ was specified for modeling these samples [Visser, 1989]. Paleozoic basement rocks were assigned an initial constraint of $550 \pm 50 \mathrm{Ma}$ and $100 \pm 100^{\circ} \mathrm{C}$ to allow freedom for the initial model conditions to extend back to the beginning of the Pan-African Orogeny. As AFT single-grain ages for 

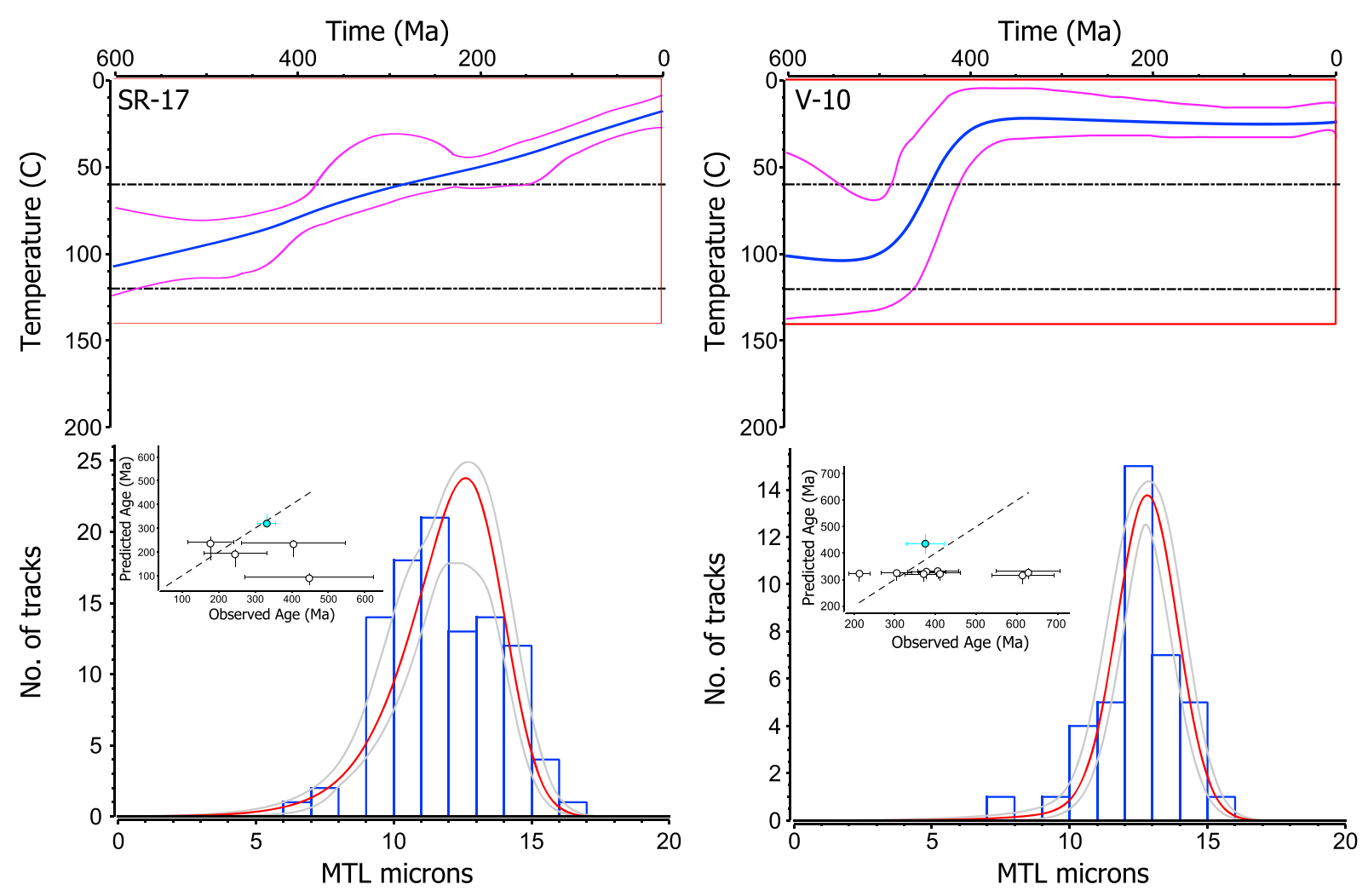

Figure 5. "Paleozoic" thermal histories: (top row) thermal history modeling results for two samples from the Kaapvaal Craton highlighting protracted (SR-17) and negligible cooling $(\mathrm{V}-10)$ from the late Paleozoic $(<300 \mathrm{Ma})$ and (bottom row) their data predictions. The blue line shows the expected model (i.e., average of all models weighted for their posterior probability); the magenta lines indicate $95 \%$ credible intervals for the expected model. The red box indicates the prior information on temperature and time (Figure 5, top row). The histogram shows the observed track-length distributions; the red curve indicates the predicted track-length distributions, and the grey curves indicate $95 \%$ credible intervals (i.e., uncertainty) for track-length distribution prediction. The inset plot shows the relationship of observed data against model-predicted data; the white circles represent single-grain AHe ages, and the blue circles represent AFT ages (Figure 5, bottom row).

Archean rocks are as old as $503 \mathrm{Ma}$, an initial constraint of $1000 \pm 100 \mathrm{Ma}$ and $100 \pm 100^{\circ} \mathrm{C}$ was used to allow freedom for the initial model conditions during the Proterozoic, allowing the data to determine the thermal history through the Pan-African. For many samples, maximum paleotemperatures are sufficiently elevated so that the AFT and AHe thermochronometers were completely reset after deposition of the Karoo (i.e., PermoTriassic). However, there are samples that possess a tail of partially annealed tracks arising from thermal histories that have had slower or more complex thermal histories $<110 \pm 10^{\circ} \mathrm{C}$. The lack of further independent geological stratigraphic evidence prevents the use of additional constraints being placed on the thermal histories.

\subsection{Results}

Models that best represent the timing of major cooling events across the Kaapvaal Craton and the adjacent mobile belt are discussed in the sections below. Thermal history models for all samples reported here can be found in Figure S5. The timing of cooling is estimated by using the expected thermal history (blue curves), which is presented with $95 \%$ credible intervals (magenta curves).

\subsubsection{On-Craton "Paleozoic" Thermal Histories}

Two samples were taken from the Archean basement rocks of the Kaapvaal Craton (SR-17 and V-10). By $300 \mathrm{Ma}$, both samples had reached $\sim 60^{\circ} \mathrm{C}$ and experienced low rates of cooling $\left(\sim 0.2^{\circ} \mathrm{C} / \mathrm{Myr}\right)$ from the Permian (300-250 Ma) to the present day. The weighted average (or expected) thermal history for sample SR-17 suggests a monotonic cooling history where the sample cools at a steady rate of $0.2^{\circ} \mathrm{C} / \mathrm{Myr}$ from the Pan-African to present day (Figure 5). A reheating event is possible, within the range of the credible intervals, between 350 and $250 \mathrm{Ma}$; however, even if this event occurred, the sample would still have remained at temperatures cooler than $60^{\circ} \mathrm{C}$. The thermal history for $\mathrm{V}-10$ predicts that the last time the sample experienced 

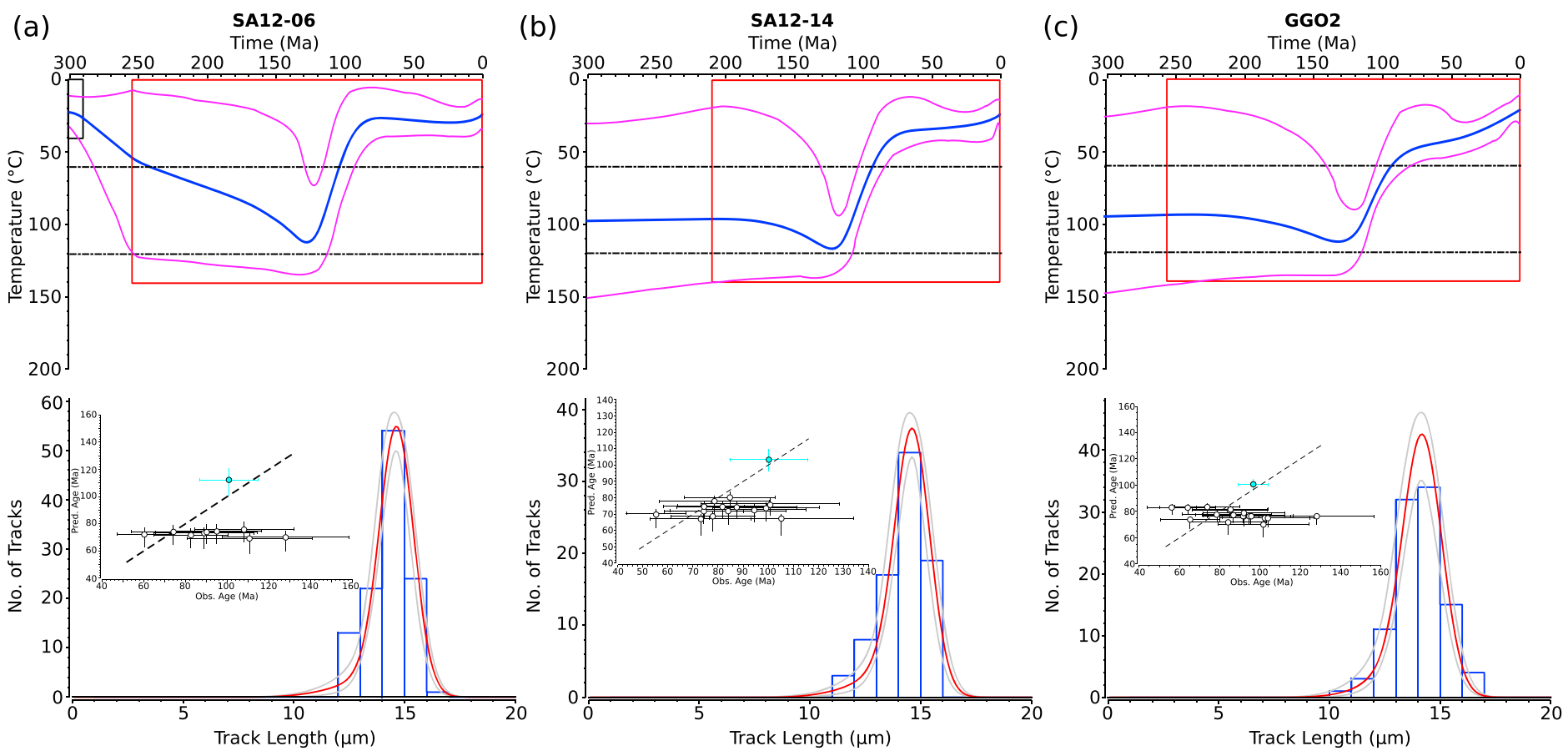

Figure 6. (a-c) "Early Cretaceous" thermal histories: (top row) thermal history modeling results for two samples from the Dwyka Group (SA12-06) and Namaqualand Mobile Belt (SA12-14 and GGO2) that show the onset of crustal cooling in the Early Cretaceous and (bottom row) their data predictions. See Figure 5 for symbol details.

elevated temperatures of $\sim 100^{\circ} \mathrm{C}$ was approximately at $500 \mathrm{Ma}$. Cooling is predicted to have occurred at a rate $0.8^{\circ} \mathrm{C} / \mathrm{Myr}$ until $400 \mathrm{Ma}$ with no additional subsequent cooling to present day (Figure 5 ).

\subsection{2. "Early Cretaceous" Thermal Histories}

Two samples (SA12-05 and SA12-06B) were taken from the Dwyka Group outcrop in the east of the Bushmanland Plateau study area, which covers the southwest corner of the Kaapvaal Craton. They are constrained at the surface in the Permo-Carboniferous. In both thermal histories, the samples are heated to $\sim 110-115^{\circ} \mathrm{C}$ by the Late Jurassic-Early Cretaceous before cooling initiates at 130-120 Ma (SA12-06B, Figure $6 a$ and SA12-05, Figure S5) at rates of $\sim 1.5$ to $2.5^{\circ} \mathrm{C} /$ Myr. Following this, the cooling rate decreases until near-surface temperatures are reached at $70 \mathrm{Ma}$ until present day. The style of cooling history shown by these samples is also seen by SA12-09 (see Figure S5). Further west, SA12-19B, SA12-14, and GGO2 (Figures 6 and S5) also imply the onset of cooling during the Early Cretaceous. The models also have an initially rapid pulse of cooling at rates of 1 to $1.6^{\circ} \mathrm{C} / \mathrm{Myr}$ followed by slower cooling $\left(0.2\right.$ to $0.6^{\circ} \mathrm{C} / \mathrm{Myr}$; Figures $6 \mathrm{~b}$ and $\left.6 \mathrm{c}\right)$. The data fit for Early Cretaceous cooling models is generally good, particularly for the AFT data. Factors affecting the discrepancies between observed and predicted AHe ages (Figure 6) are numerous and complex, and, as discussed above, our understanding of the He system and the parameterization of the diffusion models is still evolving [Shuster et al., 2006; Green et al., 2006; Flowers et al., 2009; Gautheron et al., 2009, 2013; Brown et al., 2013; Mbongo-Djimbi et al., 2015]. A consistent observation is that the younger AHe ages are better reproduced by the model, while the older ages are underpredicted. This is consistent with our current understanding on how radiation damages repair over time and temperature and interact at high densities [Ketcham et al., 2013; Gerin et al., 2017]. Despite the discrepancy between the predicted and model AHe ages, the thermal histories produced are those that best fit the observed data, considering the given uncertainty ranges. As the observed AHe ages have a larger uncertainty than the AFT data and are resampled within that uncertainty range during the Bayesian inversion, they have less weighting on the thermal history model than the AFT data.

Early Cretaceous cooling is also recorded along the southern margin of the Kaapvaal Craton in sample S- 25 (Figure S5). As this sample is from the Upper Beaufort group formation, it is constrained at the surface during the Lower Triassic. The sample is progressively heated until it reaches $120^{\circ} \mathrm{C}$ at $160-170 \mathrm{Ma}$. It is possible that this sample was buried under a thick (>1 km) succession of Karoo flood basalts at 180 Ma [Duncan et al., 1997; 
(a)

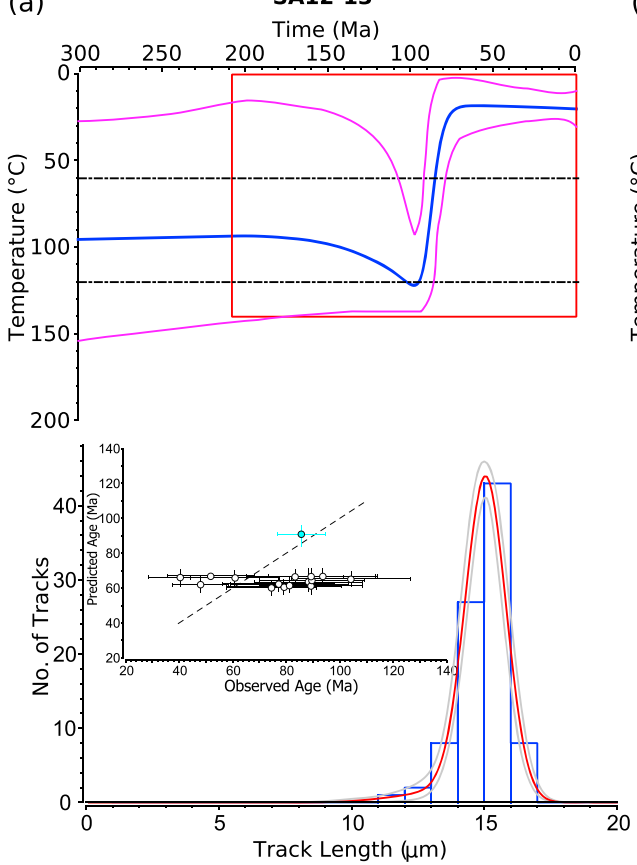

(b)
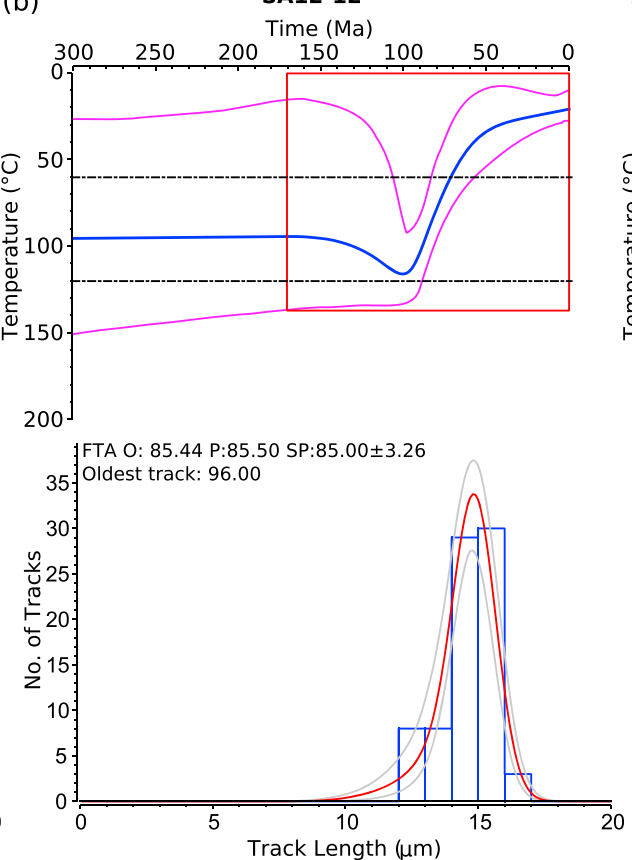

(c)

SA12-11
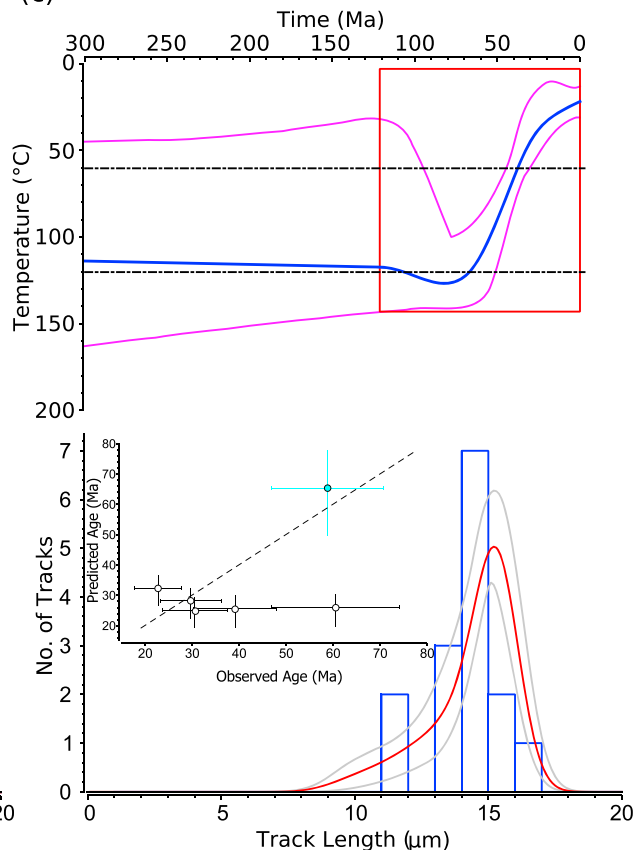

Figure 7. $(\mathrm{a}-\mathrm{c})$ "Late Cretaceous" thermal histories: (top row) thermal history modeling results for three samples from the Namaqualand Mobile Belt that show the onset of crustal cooling in the Late Cretaceous and (bottom row) their data predictions. See Figure 5 for symbol details.

Jourdan et al., 2005, 2007; Moulin et al., 2011; Svensen et al., 2012] and a component of this cooling may be a result of thermal relaxation following the magmatic episode.

\subsection{3. "Late Cretaceous" Thermal Histories}

Almost half of the samples from the Bushmanland Plateau record the onset of cooling during the middle-toLate Cretaceous from 110 to $70 \mathrm{Ma}$. Moreover, cooling at this time is typically more rapid than cooling observed in the Early Cretaceous ( 1.5 to $2.5^{\circ} \mathrm{C} / \mathrm{Myr}$ ). Sample SA12-13A shows the most rapid cooling rates at almost $5^{\circ} \mathrm{C} /$ Myr for $\sim 20 \mathrm{Myr}$ (Figure 7a).

Slower cooling initiating at this time is predicted by the results for samples SA12-10 and SA12-15 (Figure S5). However, limited track length data were obtained for both of these samples ( 9 and 17 tracks, respectively). Also, SA12-10 yielded limited single-grain $F_{t}$ ages (12 crystals), and although SA12-15 is supplemented with two AHe ages, these AHe ages span a range of $100 \mathrm{Ma}$. The data quality for both of these samples is relatively poor. Consequently, the potential to resolve detail in the thermal histories is low and the results suggest a monotonic cooling history. While this style of thermal history is possible and may reflect regional variations in denudation, we advocate that the dominant cooling style over the Late Cretaceous was fairly rapid.

Sample SA12-11 shows cooling beginning at 80-75 Ma at a rate of $1.4^{\circ} \mathrm{C} / \mathrm{Myr}$ until the present day (Figure $7 \mathrm{C}$ ), although the paucity of measurable track lengths leaves the structure of the track length distribution poorly defined. However, the cooling episode is supported by the young AHe ages (16-38 Ma). Both the AFT age and AHe ages are reproduced well by the model, and it is significant that cooling at this time (80-60 Ma) has been well documented in northern Namibia, linked to the reactivation of large-scale structures within the PanAfrican age Damara Belt [Raab et al., 2002, 2005; Brown et al., 2014].

\section{Quantitative Constraints on the Geomorphic Evolution of the South African Plateau}

\subsection{Previous AFT and AHe Data}

Previous work in the region has included (i) AFT and AHe data from the Augrabies Falls area [Kounov et al., 2013]; (ii) AHe data from the Kaapvaal Craton, east of our study area [Stanley et al., 2015]; and (iii) AFT data along the Orange River valley [de Wit, 1988; Wildman et al., 2015] (Figure 1). 
AFT and AHe data from Augrabies Falls and from the Fish River Canyon in southern Namibia records enhanced cooling from 100 to $65 \mathrm{Ma}$ [Kounov et al., 2013]. This is in agreement with the predominant age of cooling inferred from our data and is interpreted by Kounov et al. [2013] as representing the geomorphic response to regional uplift increasing river gradients and hence erosion rates. AFT and AHe ages are reported by Kounov et al. [2013] for samples from the Augrabies Falls, and the observed ages agree with Late Cretaceous cooling inferred here. However, as acknowledged by the authors, radiation damage effects may have influenced the closure temperature of individual AHe ages and so denudation estimates are made by using AFT data from a vertical profile taken from the Orange River valley wall. Kounov et al. [2013] do not support tectonic reworking as the dominant, regional mechanism that enhanced denudation at this time but do suggest that a record of localized fault reactivation is preserved in their study areas. In the Fish River Canyon, an AFT age of $67 \pm 26 \mathrm{Ma}$ in the hanging wall is adjacent to AFT ages of $81 \pm 12$ to $84 \pm 17 \mathrm{Ma}$ in the footwall of a major thrust fault and is used to invoke almost $1 \mathrm{~km}$ of offset around $70 \mathrm{Ma}$. Due to the relative uncertainties of these fission track ages and lack of track length information to constrain their thermal history, the timing of faulting is still not well constrained. No local tectonic mechanism is suggested to have occurred in the Augrabies Falls region, which is interpreted as reflecting the regional signal of plateau uplift and denudation in the middle Late Cretaceous. While there is consistency in the timing of cooling invoked by our data and that of Kounov et al. [2013], our data suggest greater spatial variability in cooling across the Bushmanland plateau.

Although the data from Kounov et al. [2013] alone do not provide strong evidence for major structural reactivation at $\sim 70 \mathrm{Ma}$, they are supported by cooling ages from Raab et al. [2002, 2005] and Brown et al. [2014] from northwestern Namibia that also indicate a regionally significant tectonic event at this time. These authors infer that $\sim 2 \mathrm{~km}$ of vertical displacement has occurred across the OmaruruWaterberg Lineament since the Early Cretaceous, with a major period of enhanced denudation occurring at $70 \mathrm{Ma}$.

A transect of samples from the coast to the middle of our study area was collected by de Wit [1988] (Figure 1). The majority of the samples from this transect yield AFT ages between 108 and $129 \mathrm{Ma}$, with MTLs ranging from 13.3 to $14.0 \mu \mathrm{m}$. This is comparable to our AFT data from west of the craton boundary faults. Two samples from Kakamas and Kenhardt yielded AFT ages of $70 \pm 5 \mathrm{Ma}$ and $73 \pm 4 \mathrm{Ma}$ and MTLs of $13.98 \pm 0.1 \mu \mathrm{m}$ and $14.23 \pm 0.1 \mu \mathrm{m}$, respectively [de Wit, 1988]. No track length histograms are presented, but the mean track length standard deviation for these samples is low (0.88 and 1.12 and $n=74$ and 96, respectively), and it can be assumed that the track length distribution is relatively narrow. De Wit [1988] interpret these AFT data as evidence for thermal overprinting due to Late Cretaceous magmatism. The Stompoor intrusion is Late Cretaceous in age [Smith, 1986], but emplacement of other intrusive bodies in the study area occurs in the middle Cretaceous (e.g., Markt, Jonkerwater, and Middlewater) [Moore et al., 2008). The Stompoor intrusion is $\sim 30-40 \mathrm{~km}$ SW of the young AFT ages of de Wit [1988] and is unlikely to have had a thermal effect. It is possible that unknown and undated minor intrusions close to the sample locations caused thermal overprinting, but these samples are located adjacent within the structural zone that we suggest may have accommodated deformation and focused denudation during the Late Cretaceous, and this could provide an alternative explanation for these AFT data.

East of our study area, a novel approach to constraining the erosional history of the plateau was presented by Stanley et al. [2015]. In this study, 15 early and mid-Cretaceous kimberlite pipes occurring both on and off the Kaapvaal Craton were sampled. (U-Th)/He ages were obtained on apatites primarily from the kimberlite matrix itself, with additional grains from crustal xenoliths within the pipe. Uncorrected mean AHe ages range from 36 to $72 \mathrm{Ma}$ (corrected mean ages: 54-113 Ma). They concluded that an initial phase of regional erosion beginning in the Early Cretaceous was later perturbed by a spatially variable mid-Cretaceous erosion event controlled by lithospheric-mantle interactions in and around the Kaapvaal Craton. This conclusion is largely supported by our study.

AHe age-eU correlations were used by Stanley et al. [2015] to constrain the thermal history information from these samples; however, this relationship has significant uncertainty [e.g., Gautheron et al., 2013; MbongoDjimbi et al., 2015; Brown et al., 2013] and thus demonstrates the importance of modeling AHe data alongside independent information such as AFT data or well-dated geological constraints (e.g., kimberlite intrusion age) to constrain thermal histories. 
The current South African thermochronology data set for the interior plateau is dominated by a signal of middle-to-Late Cretaceous cooling. Our new AFT and AHe contribute to this data set by identifying a preserved Paleozoic history on the craton and by showing that, over the NW-SE trending structural zone at the western craton margin, the timing and style of Cretaceous cooling are spatially variable.

\subsection{Timing and Spatial Patterns of Cretaceous Denudation}

The magnitude of denudation has been calculated by using the thermal history models of Kounov et al. [2013] and Wildman et al. [2015, 2016] and new models presented here, assuming a geothermal gradient of $25^{\circ} \mathrm{C} / \mathrm{km}$ [e.g., Jones, 1987] (Figure 8). Denudation estimates were made for each individual sample simply by dividing the temperature change of the sample over the specified time interval, as predicted by the expected thermal history model by the assumed geothermal gradient (see Figure S6 for more details). Inferring the magnitude of denudation across the study area during the Early Cretaceous is difficult because many samples have not yet cooled below $110 \pm 10^{\circ} \mathrm{C}$ and therefore do not record cooling over this time. A greater number of models record cooling that initiates closer to $\sim 130 \mathrm{Ma}$, leaving uncertainty on paleotemperatures before this time. Thermal histories that best constrain cooling over this time (see Figure S5) suggest that denudation could have been as high as $2 \mathrm{~km}$ (FS1605) and was probably at least 1 km across most of the region (e.g., S-25) except for the most interior Archean samples, which suggest that denudation was minimal $<0.2 \mathrm{~km}$ over this time.

The thermal history information is better constrained through the middle Late Cretaceous (110-70 Ma) but implies significant heterogeneity of denudation across the plateau (Figure 8). Archean samples in the center of the craton continue to show minimal denudation $(<0.3 \mathrm{~km})$. Across the rest of the study area, denudation estimates range from 0 (e.g., PRU106) to $4.2 \mathrm{~km}$ (8732-93). Samples in the southwest corner of the study area are characterized by these larger magnitudes $(\sim 3.5-4 \mathrm{~km})$ (e.g., of denudation, suggesting that this section of the plateau experienced the same intense period of erosion). In the east of the study area, samples that began cooling in the Early Cretaceous continue to be exhumed but with the removal of less rock than in the west (1-2.2 km as predicted by S-25 and SA12-06B, respectively). Within the heavily faulted zone at the boundary between the Paleozoic mobile belt and Archean craton, denudation is more variable over shorter scales. The regional average denudation (excluding the Archean samples) is $2.5 \mathrm{~km}$ however, samples such as SA12-13A and 8732-93 predict that denudation may have been as much as $4 \mathrm{~km}$. At the other extreme, the thermal history model of PRU106 suggests that the sample was not exhumed and may have experienced limited burial during this period. Samples such as GGO2, SA12-09, and SA12-08 suggest similar magnitudes of denudation compared to that predicted by samples east of the structural zone $(1.7-2.3 \mathrm{~km})$.

Predicting where the eroded continental interior material has ended up is difficult due to uncertainties over the Cretaceous drainage network during the prerift, synrift, and postrift phases [De Wit, 2007]. It is suggested by many workers though that the westward drainage of Southern Africa has persisted since continental breakup, but internal drainage reorganizations may have altered the position of the major drainage outlet over this time and interior drainage patterns [de Wit, 1999; Moore and Larkin, 2001; Stevenson and McMillan, 2004; Goudie, 2005]. Episodic drainage reorganizations may have occurred during the Cretaceous and early Cenozoic, related to periods of tectonic uplift of the continent at these times [Partridge and Maud, 1987; Dollar, 1998; Goudie, 2005; Moore et al., 2009]. It is likely that most of the eroded material was transported to the nascent Orange Basin, although drainage to interior basins (e.g., Kalahari basin) cannot be ruled out entirely.

Two prominent peaks in accumulated sediment volume and sedimentation rates occur during the Early Cretaceous synrift phase and in the Late Cretaceous in the Orange Basin [Rouby et al., 2009; Guillocheau et al., 2012]. The timing of sedimentation is broadly coeval with the timing of onshore denudation along the continental margin [Wildman et al., 2016] and interior plateau, as described here. Middle-to-Late Cretaceous denudation has been predicted along the southern margin and interior plateau [Tinker et al., 2008; Wildman et al., 2015; Stanley et al., 2013; Green et al., 2016] and correlates with a peak in sediment volumes in the Bredasdorp and Outeniqua Basins [Tinker et al., 2008].

\subsection{Timing and Spatial Patterns of Cenozoic Denudation}

Throughout the Cenozoic (70-0 Ma) the interior Archean samples continue to record minimal levels of denudation. SR-17 suggests that $1 \mathrm{~km}$ of material has been removed with $\sim 800 \mathrm{~m}$ of this being eroded in the last 

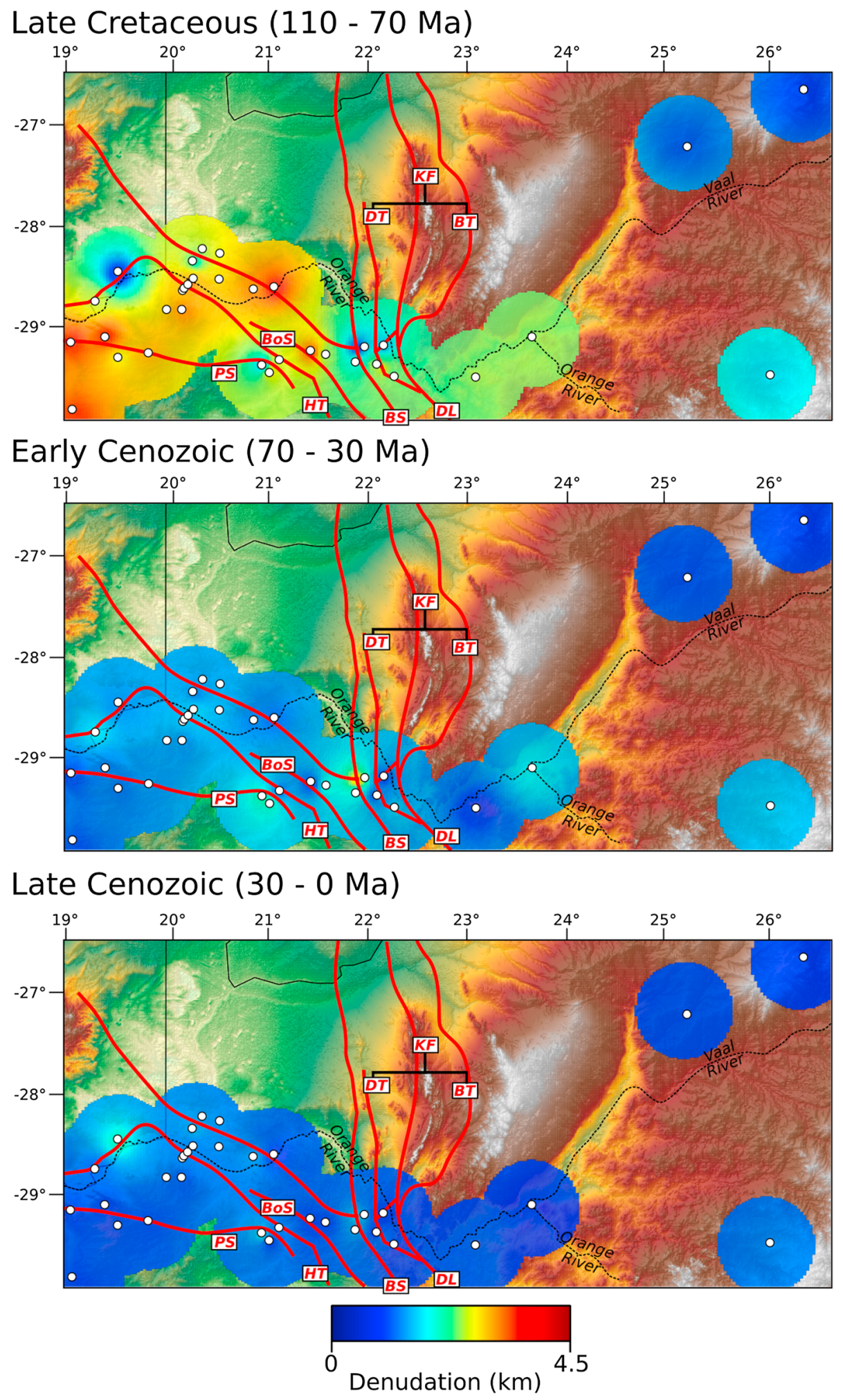

Figure 8. Interpolation map for the Late Cretaceous, early Cenozoic, and late Cenozoic based on denudation estimates extracted from thermal history models. The estimates were made by using a geothermal gradient of $25^{\circ} \mathrm{C} \mathrm{km}^{-1}$ and the change in temperature of expected thermal history models over the specified time interval (cf. Figures 1 and 2 for sample and fault names). Full details on denudation estimates including uncertainties on each measurement are given in Figure S6. The interpolation map was created by using an Inverse Distance Weighted interpolation technique in QGis. The interpolation was clipped to a buffer with a radius of $0.5^{\circ}$ for each sample. 
$30 \mathrm{Ma}$. However, as the sample resided at temperatures less than $40^{\circ} \mathrm{C}$ through this time, it is beyond the sensitivity of the AFT and AHe techniques, and so these should be regarded as maximum estimates of erosion. Unlike during the Cretaceous, the magnitudes of denudation during the Cenozoic predicted across the whole of the study area are quite similar. The regional averages for the early and late Cenozoic are 0.7 and $0.3 \mathrm{~km}$, respectively. During the Cenozoic there are localized occurrences of higher denudation recorded primarily in the samples that started to cool during the Late Cretaceous at slow rates and were finally brought to nearsurface temperatures in the Cenozoic. An exception to this is SA12-11, located among the Kheis Front faults, which was still at temperatures $>100^{\circ} \mathrm{C}$ by the end of the Cretaceous. This is anomalous, considering the regional denudation estimates; however, this thermal history is consistent with the Cenozoic AFT and AHe ages obtained for the sample. Another exception is PRU106, which is characterized by long residence at $\sim 70^{\circ} \mathrm{C}$ before rapidly cooling over the last $30 \mathrm{Ma}$.

The constraints provided here on the timing and magnitudes of continental denudation have major implications for the long-term geomorphic development of the South African interior plateau. The extensive AFT and AHe data set can be combined with a wealth of cosmogenic nuclide data from South Africa constraining more recent erosion rates [e.g., Fleming et al., 1999; Cockburn et al., 2000; Bierman and Caffee, 2001; van der Wateren and Dunai, 2001; Codilean et al., 2008, 2014; Decker et al., 2011; Kounov et al., 2007, 2015; Scharf et al., 2013; Erlanger et al., 2012; Bierman et al., 2014]. Together, these data sets indicate that regional erosion rates over the Cenozoic, and particularly the late Cenozoic, were low ( $<20 \mathrm{~m} / \mathrm{Myr}$ ) relative to the Cretaceous; however, faster erosion rates (27-160 m/Myr) have been be observed locally, associated with local channel incision in the Drakensberg Escarpment [Fleming et al., 1999] and the Kuiseb River Valley in northeastern Namibia [van der Wateren and Dunai, 2001]. These rates are also similar to those suggested by our sample PRU106. The preservation of Late Cretaceous crater facies within kimberlite pipes and their infill lacustrine sediments provide additional evidence for minimal erosion of the plateau through the Cenozoic [Stanley et al., 2013, 2015; Hanson et al., 2009; Smith, 1986]. These low erosion rates and amounts of Cenozoic erosion onshore are reflected in the low rates of sediment accumulation in offshore basins on the western margin of South Africa throughout the Cenozoic [Guillocheau et al., 2012; Tinker et al., 2008; Rouby et al., 2009].

\section{Post $300 \mathrm{Ma}$ Evolution of the South African Plateau}

\subsection{Paleozoic Evolution}

The data presented here, combined with previously published low-temperature thermochronology data sets, provide evidence that, while the center of the Kaapvaal Craton has remained at relatively low temperatures $\left(<60^{\circ} \mathrm{C}\right)$ since the end of the Carboniferous, the craton margins and off-craton regions have experienced younger Mesozoic cooling. The thermal history models suggest that interior craton samples underwent their main cooling phase between 600 and $400 \mathrm{Ma}$, which is coeval with the Pan-African Orogeny. Although only two samples define this preserved Paleozoic history, they are immensely important, as until now, AFT and AHe data have shown that parts of the elevated cratonic interior and its margins were significantly eroded during the Mesozoic [Stanley et al., 2013, 2015; Flowers and Schoene, 2010; Tinker et al., 2008]. Diamondbearing gravels unconformably overlying the Transvaal Supergroup rocks $\sim 30 \mathrm{~km} \mathrm{~N}$ and NW of sample V10 have previously been interpreted as post-Gondwana drainage deposits [e.g., Partridge and Maud, 1987]. However, a reinterpretation of these gravels based on their lithofacies and age dating from inclusions in diamond and zircon suggest that the gravels are most likely semilithified paleoeskers associated with the deglaciation of the Dwyka ice sheet during the Permian to Carboniferous [de Wit, 2016]. The preservation of these features and presence of only limited remnants of Ecca Group sediments [Beukes et al., 1999] support the proposal that this part of the craton was only covered by a thin layer of Karoo sediments and did not experience significant erosion over the last $300 \mathrm{Ma}$ (Figure 9).

\subsection{Mesozoic Evolution: Late Jurassic-Early Cretaceous}

The onset of Gondwana breakup is marked by the widespread emplacement of Karoo flood basalts at $\sim 183 \mathrm{Ma}$ [Svensen et al., 2012]. These basalts are best preserved in the Drakensberg Mountains in southeastern South Africa and likely extended across all of Southern Africa. The thermal effect, either due to direct heating or burial, of these basalts on apatite thermochronometery is still unclear. Due to the preservation of older (195-220 Ma) ages with only partially annealed tracks in samples from the Karoo Basin underlying the Drakensberg Basalts, direct thermal heating is not thought to have affected the AFT data of some 

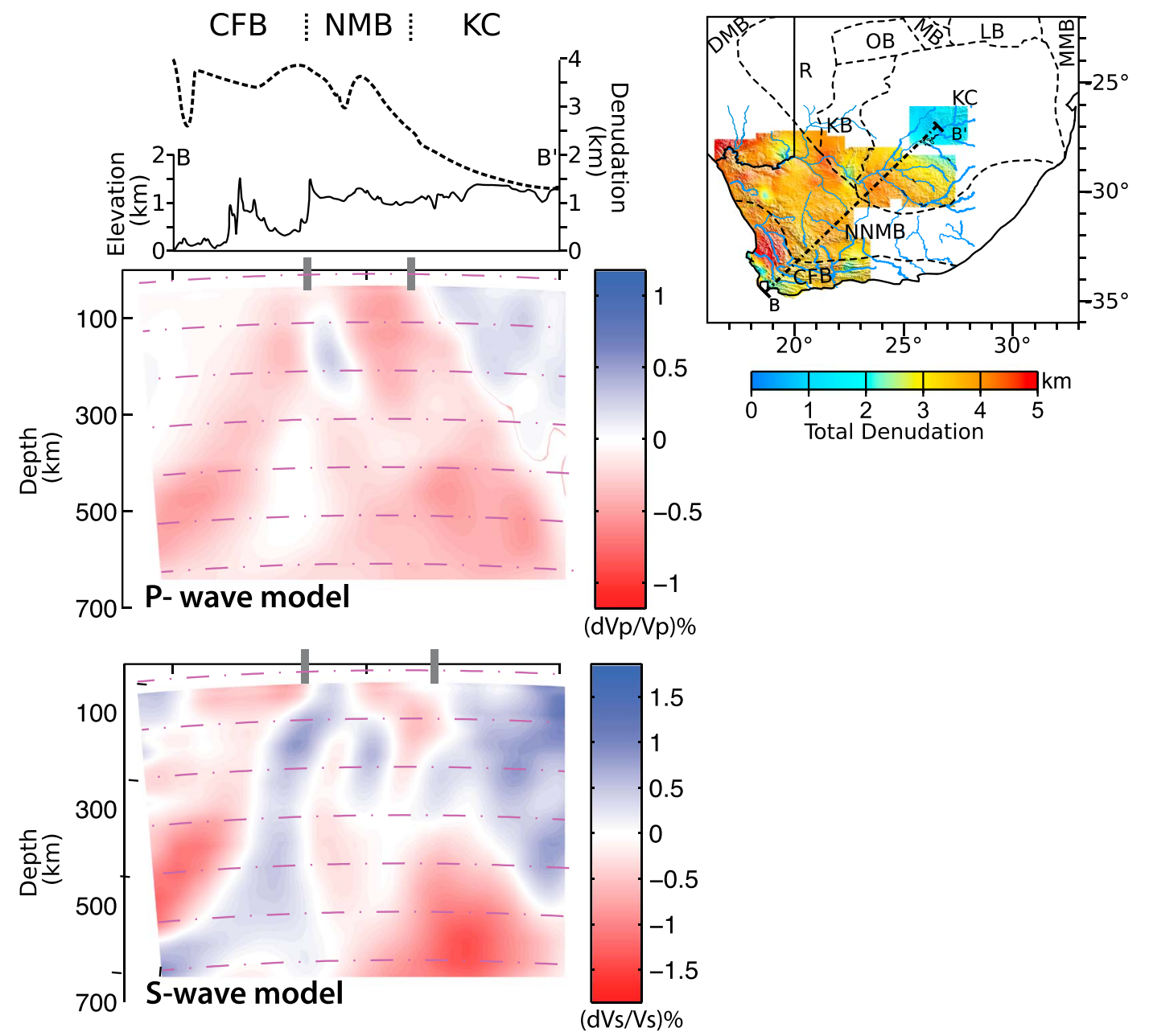

Figure 9. Regional cross section showing total denudation across the Cape Fold Belt (CFB), Namaqua-Natal Mobile Belt (NNMB), and Kaapvaal Craton (KC) calculated by using data from Wildman et al. $[2015,2016]$ and this study. Lower plots show $P$ and $S$ vertical sections for $P$ and $S$ wave velocity maps [Youssof et al., 2015], which defines the inland sloping boundary (i.e., craton edge) between thick and depleted mantle lithospheres below the $K C$ and thinner, fertile lithosphere beneath the NNMB and CFB. The inset map shows total magnitudes of denudation predicted across southwestern Africa based on published thermochronology data. Interpolation performed as in Figure 8. We highlight that denudation is predicted to be higher southwest of the craton edge than on the craton itself.

Karoo samples [e.g., Brown et al., 2002]; however, Kounov et al. [2009] advocate that AFT data from the Karoo Basin in southwestern Africa provide evidence for resetting due to Karoo magmatism. These observations are not incompatible and simply indicate that the thermal effect of the Karoo magmatic event was spatially heterogeneous, and this is consistent with an earlier quantitative analysis of the thermal effects of the Karoo igneous event involving both extrusive and intrusive bodies [Brown et al., 1994]. Our data presented in this paper do not record any heating or cooling that can be directly attributed to the thermal effects of Karoo magmatism; however, the presence of basaltic xenoliths in kimberlites emplaced between 120 and $140 \mathrm{Ma}$ suggests that flood basalts at least covered the southern Kaapvaal Craton. No direct evidence is available to suggest that the basalts covered samples SR-17 and V-10 in the center of the craton [de Wit, 2016].

Early Cretaceous cooling is broadly coeval with the opening of the southern Atlantic and has been recorded in samples across the SW Cape [Kounov et al., 2009; Wildman et al., 2015, 2016]. Kilometer scale denudation in response to continental rifting has been well documented [Gallagher and Brown, 1999; Brown et al., 2002; Van der beek et al., 2002; Gunnell et al., 2003; Persano et al., 2005]. The Early Cretaceous cooling episode is therefore interpreted to have been caused by enhanced erosion in response to the breakup of western Gondwana and 
$110 \mathrm{Ma}$

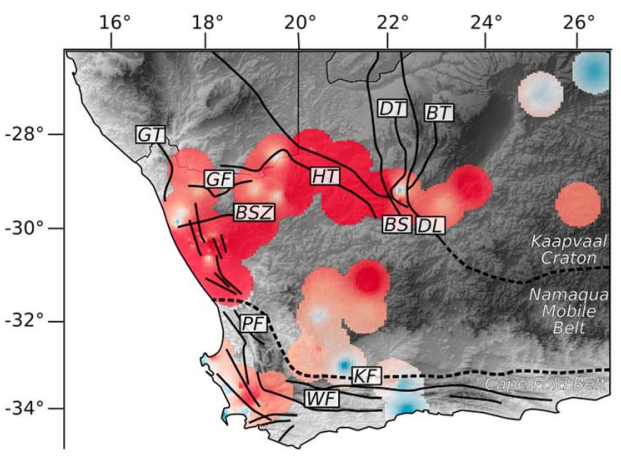

$80 \mathrm{Ma}$

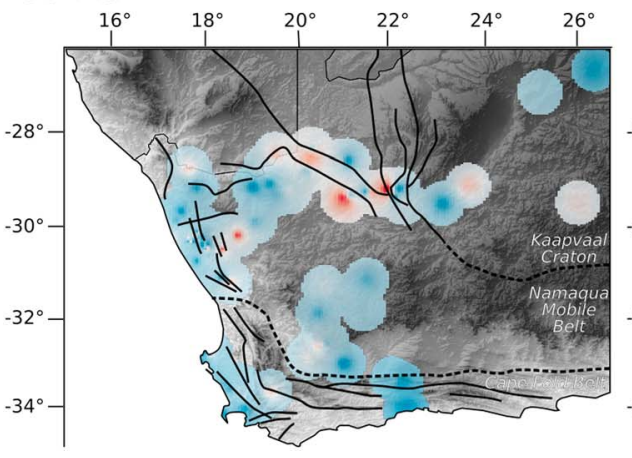

$100 \mathrm{Ma}$
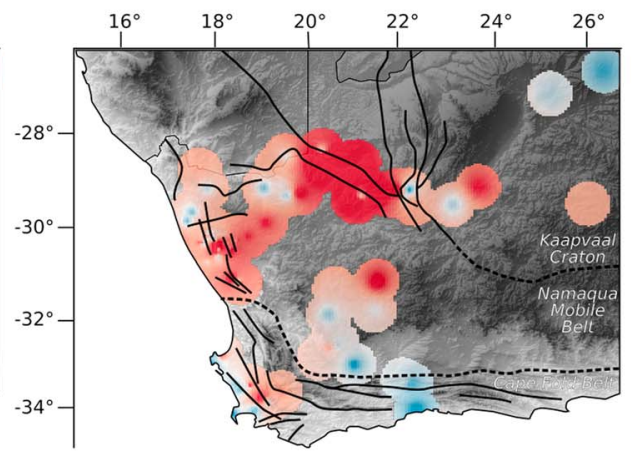

$70 \mathrm{Ma}$

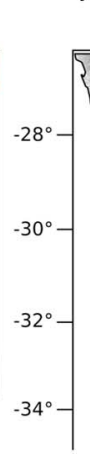

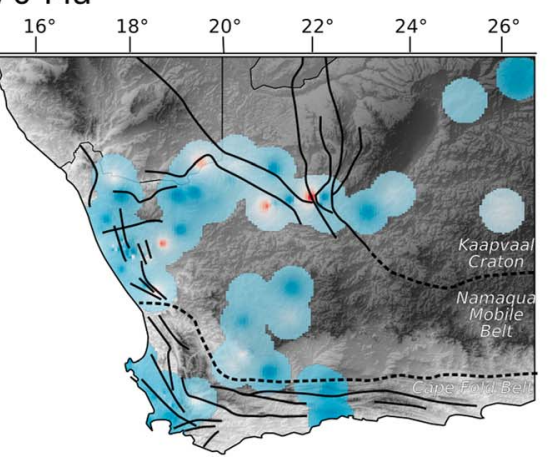

$90 \mathrm{Ma}$
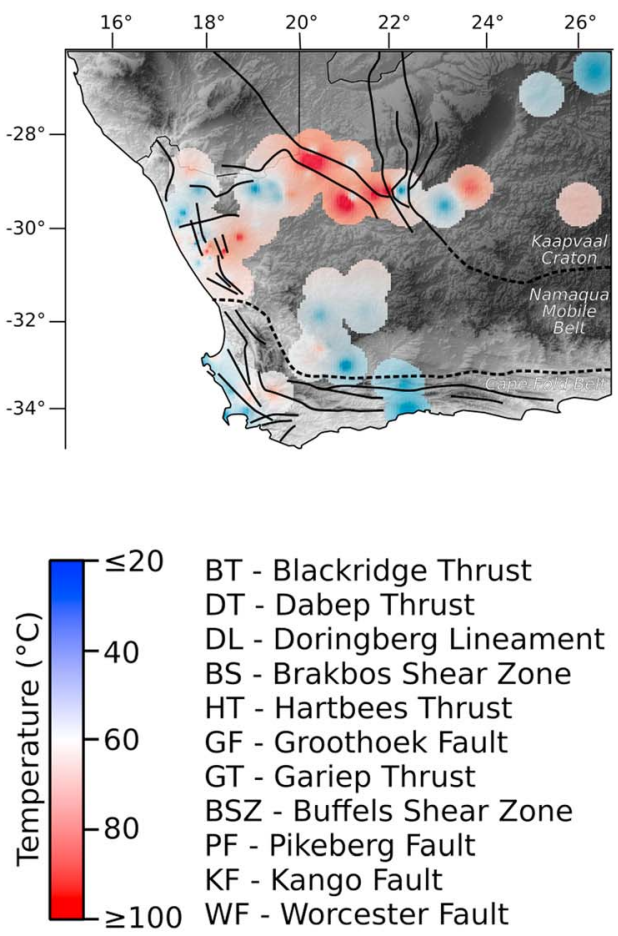

BT - Blackridge Thrust DT - Dabep Thrust DL - Doringberg Lineament BS - Brakbos Shear Zone HT - Hartbees Thrust GF - Groothoek Fault GT - Gariep Thrust BSZ - Buffels Shear Zone PF - Pikeberg Fault KF - Kango Fault WF - Worcester Fault

Figure 10. Maps of sample paleotemperature at different time steps over the Late Cretaceous period (110-70 Ma). Paleotemperatures were obtained from the expected thermal history models presented in this study as well as those presented by Wildman et al. [2015, 2016]. The interpolation and masked data used are the same as those described in Figure 6. The maps highlight the major regional cooling of southwestern Africa during the Late Cretaceous and also highlight the spatial variability of sample cooling.

lowering of regional base levels. It has now been clearly shown by data presented here and previously by Wildman et al. [2015, 2016], Kounov et al. [2009], and Tinker et al. [2008] that Early Cretaceous erosion occurred across what is now the southwest African plateau. Major drainage conduits such as the paleoOrange River transmitted the base-level drop associated with the opening of the Atlantic several hundreds of kilometers inland. It is possible that much of the Karoo basalts were stripped from southwest Africa during this phase of enhanced erosion prior to the second phase of kimberlite intrusive activity $(\sim 100-85 \mathrm{Ma})$ [Hanson et al., 2009; Stanley et al., 2013, 2015].

\subsection{Mesozoic Evolution: Late Cretaceous}

The Late Cretaceous period of South Africa's evolution is a time of significant change, with plate tectonics and mantle dynamics coupling to produce a complex tectonic and geomorphic development of the subcontinent. In a regional context, thermochronology consistently supports major cooling of the South African crust in the Late Cretaceous (Figure 10). However, in detail, particularly at continental margins and structurally complex zones, variation in the timing and rate of Late Cretaceous cooling is evident (e.g., western South African margin [Kounov et al., 2009; Wildman et al., 2016], southwest Cape [Wildman et al., 2015], Cape Fold Belt [Green et al., 2016; Tinker et al., 2008, northwestern Namibia [Raab et al., 2002, 2005; Brown et al., 2014], and southern Zimbabwe [Belton and Raab, 2010]) (Figure 10). We suggest that the complex spatial patterns of Late Cretaceous denudation implied by the AFT and AHe data across the craton boundary faults provide further evidence that the driving mechanism behind Late Cretaceous evolution involved both a regional component as well as more focused deformation at tectonically weak zones.

Erosional unconformities, regression wedges, and slumping/gravitational tectonics during the Late Cretaceous have been identified in seismic stratigraphic analyses of the South African offshore basins [Brown et al., 1995; McMillan, 2003; de Vera et al., 2010]. These features provide corroborating evidence for 
downward migration of the shoreline and long-wavelength regional uplift of the continent. Westward tilting involved during this uplift may explain the relative timing of offshore accumulation in the western and eastern basins [Braun et al., 2014].

The presence of a large mantle plume, or plumes, beneath the African continent [e.g., Nyblade and Robinson, 1994; Lithgow-Bertelloni and Silver, 1998; Brandt et al., 2012; Fishwick and Bastow, 2011] has often been cited as a mechanism to drive regional uplift and support the elevated African topography over long timescales [Gurnis et al., 2000; Roberts and White, 2010; Braun et al., 2014; Moucha and Forte, 2011]. However, the predicted spatial pattern, timing, and amount of "dynamic" uplift and subsidence for Africa are still unresolved [Moucha and Forte, 2011; Braun et al., 2014; Flament et al., 2014], and isolating the mantle "dynamic" uplift contribution from that of isostatically compensated topography remains challenging [e.g., Molnar et al., 2015; Colli et al., 2016; Artemieva and Vinnik, 2016].

Recent thermomechanical models have shown that the interaction of horizontal plate movement and convection in the mantle drives vertical motions of the crust over different wavelengths [Colli et al., 2014; Cloetingh et al., 2013; García-Castellanos and Cloetingh, 2011; Cloetingh and Burov, 2011; Burov and Cloetingh, 2009]. In particular, it has been shown that, during mantle upwelling, bending of the brittle crust induces lateral stresses and instabilities which may promote short wavelength, asymmetric, and topographic features (i.e., fault block movement and flexural upwarps) [Burov and Guillou-Frottier, 2005; Burov and Gerya, 2014].

Craton edges are characterized by abrupt variations in lithospheric thickness. For the Kaapvaal Craton the mantle lithosphere is $\sim 260-350 \mathrm{~km}$ thick compared to the $\sim 200 \mathrm{~km}$ thick mobile belts, with an abrupt transition zone at the edge [Delph and Porter, 2015; Youssof et al., 2013, 2015; Sodoudi et al., 2013] (Figure 9). Thermochemical modification has been suggested to have caused the off-craton lithosphere to thin by $\sim 30-40 \mathrm{~km}$ during the Late Cretaceous [Kobussen et al., 2008; Griffin et al., 2009; Janney et al., 2010]. Changes in the deep Earth structure and/or composition may induce edge-driven convection or focus upwellings in the mantle around the craton [Guillou-Frottier et al., 2012] or may well result in the off-craton and oncraton regions responding differently to unloading and stress [Gilchrist and Summerfield, 1990; Pérez-Gussinyé and Watts, 2005]. Moreover, additional contrasting geophysical characteristics at craton margins such as lateral variations in lithospheric strength, rheology, heat flow, and the presence of pre-existing weak zones have been shown to cause intraplate stresses to build up at the craton margins [Redfield and Osmundsen, 2014; Gueydan et al., 2014; Lenardic et al., 2003; Baptiste et al., 2012; Wang et al., 2014; Calignano et al., 2015; Janney et al., 2010].

These lithospheric properties have the potential to create surface topography over different length scales in response to vertical and horizontal forcings, which, when eroded, can leave a complex thermochronology record. We suggest that our data indicate that denudation was greatest at the southwest margin of the Kaapvaal Craton in the Late Cretaceous, while the craton itself remained relatively stable and preserved the older Early Cretaceous and Paleozoic thermal history of the plateau. Our data set suggests that the spatial pattern of Late Cretaceous denudation is extremely variable; however, additional sampling and multisample modeling approaches in future studies will increase the spatial resolution and robustness of denudation estimates across the plateau.

Our data do not have the precision or local coverage to constrain magnitudes of fault reactivation on specific faults. However, the buildup of stresses at the structurally weak craton margin in response to changes in African plate velocity and rotation orientation during the middle Late Cretaceous [Colli et al., 2014; Müller et al., 2008; Labails et al., 2009; Eagles, 2007; Heine et al., 2013; Moulin et al., 2010; Torsvik et al., 2009; Granot and Dyment, 2015] may have triggered transpressional faulting of shear zones that involved relative vertical movement of individual fault blocks. This structural style has been described theoretically [e.g., Christie-Blick and Biddle, 1985; Fossen and Tikoff, 1998] and is suggested to have occurred during reactivation of basement structures at $90 \mathrm{Ma}$ along the Limpopo belt, which defines the southern margin of the Zimbabwe Craton [Belton and Raab, 2010].

Recent South American-African plate reconstruction models have predicted that deformation along continental margins and within interior shear zones and rift basins during the Cretaceous normal polarity superchron (chron CM0-C34) is required in South America [Torsvik et al., 2009; Heine et al., 2013; Pérez-Díaz and Eagles, 2014]. The data presented here indicate that this has occurred within Southern Africa too. However, 
additional evidence will be required to document the reactivation of specific faults at the southwestern margin of the Kaapvaal Craton.

\subsection{Cenozoic Evolution}

Several geomorphological studies have advocated that the first-order topography of South Africa was formed by a major Cenozoic phase (or phases) of uplift and erosion [e.g., King, 1955; Partridge and Maud, 1987; Burke, 1996; Burke and Gunnell, 2008; Roberts and White, 2010; Rudge et al., 2015]. Many of the early geomorphological studies are based on the concept of the formation of continent-wide planation surfaces formed by prolonged erosion that are subsequently dissected by later erosion events following regional uplift of lowering of base level, and therefore, their remnants can be extrapolated regionally. The occurrence and significance of continental erosion surfaces as geomorphic markers have been thoroughly discussed with frequent reference to the African case [e.g., Dixey, 1955; King, 1955; Ollier and Marker, 1985; Summerfield, 1985; Partridge and Maud, 1987; Van der Beek et al., 2002; Burke and Gunnell, 2008; Green et al., 2013].

Recent numerical modeling approaches have attempted to unravel the uplift history of Africa by inverting the physiography of drainage networks over time [e.g., Roberts and White, 2010; Paul et al., 2014; Rudge et al., 2015], starting with the initial condition that Africa was characterized by low-lying and low-relief surface with no notable topography prior to $30 \mathrm{Ma}$. This assumption is largely based on the work by Partridge and Maud [1987] and summarized more recently by Burke and Gunnell [2008]. The hypothesis that the present-day topography of Southern Africa formed following the uplift and erosion of an initially flat, low-elevation landscape over the last $30 \mathrm{Ma}$ is difficult to reconcile with our data or the existing cosmogenic data that indicate low regional erosion rates during the Cenozoic. The creation of $\sim 1 \mathrm{~km}$ of relief across the continental margins, such as at the present escarpment zone, would require the removal of several kilometers of rock to overcome isostatic compensation and would therefore be recorded by the thermochronological data along the coastal plain [Van der Beek et al., 2002; Brown et al., 2002].

In contrast, the preservation of Cretaceous topography through the Cenozoic can be explained by the onset of relative tectonic stability at this time [Torsvik et al., 2009; Nürnberg and Müller, 1991; Ganerød et al., 2011; Gaina et al., 2013; Heine et al., 2013; Pérez-Díaz and Eagles, 2014; Gorczyk and Vogt, 2015] with additional moderation of erosion due to the exposure of more resistant basement rock [e.g., Cockburn et al., 2000; Scharf et al., 2013] and the onset of a more arid climate [e.g., de Wit, 1999; Gutzmer and Beukes, 2000; Bamford, 2000] following the warm, very humid climate that prevailed during the Paleocene-Eocene thermal maximum [Zachos et al., 2001]. During this time, laterite weathering profiles formed on the relic Cretaceous landscape [e.g., Dauteuil et al., 2013, Chardon et al., 2016] and are still intact in many places.

Any Cenozoic surface uplift of Southern Africa cannot therefore be accompanied by major (i.e., km scale), regional erosion, and any geomorphic response was restricted to moderate erosion $(<1 \mathrm{~km})$ and local channel incision [e.g., Dauteuil et al., 2013; Fleming et al., 1999; van der Wateren and Dunai, 2001]. Significantly, dated river terrace sequences on both the lower Orange River (west coast) and the Sundays river (south east coast) provide constraints on Cenozoic incision and rock uplift for these locations during the Neogene and indicate low-tomoderate rates of incision of 4.4-16 m/Ma [Erlanger et al., 2012; Bierman et al., 2014; Dauteuil et al., 2013]. Prior to the onset of the present-day semiarid climate [Pickford and Senut, 1997], a slightly more humid climate prevailed during the early-middle Miocene. This wetter climate may have intensified river incision and enhance relief on the scale of tens to hundreds of meters [Mvondo et al., 2011; Dauteuil et al., 2013].

It is unlikely, though, that late Cenozoic erosion is only linked to climate changes because there is good evidence of sea level fluctuations [Roberts et al., 2011], neotectonic fault activity [de Beer, 2012], and the effects of small-scale mantle convection [e.g., Moucha et al., 2008] causing vertical surface motions and throughout the Cenozoic. The key conclusion is that the thermochronometry data and modeling, coupled with cosmogenic isotope constraints and the geological constraints onshore and offshore, are inconsistent with the hypothesis that the current topography of South Africa evolved from a low-relief, low-elevation landscape over the last 30 Myr. It is important to emphasize that we do not suggest that no variation in elevation or topography has occurred during the Cenozoic, but only that any change was not accompanied by major (km scale) regional erosion. 


\section{Summary and Conclusions}

The study of the origin and longevity of South Africa's interior plateau has recently focused on the influence of regional dynamic uplift arising from a buoyant source in the mantle. However, vertical motions stemming from the mantle will couple with the regional in-plane stress field and, depending on the preexisting structure, may induce different styles of deformation over different length scales. This regional uplift and localized deformation will result in complex patterns of denudation as new topography is eroded.

In the South African case, a change in lithospheric thickness between the Kaapvaal Craton and Namaqua mobile belt focuses stress at the craton margin that will be augmented by changes in relative plate motions in the middle Late Cretaceous. Thermal modification of the lithosphere as recorded by ubiquitous temporally and chemically distinct kimberlite intrusions indicates the possible initiation or impact of a thermal anomaly at the base of the lithosphere during the middle Late Cretaceous. The vertical stresses imposed by a buoyant thermal upwelling may have driven long wavelength uplift of the strong, undeformed, cratonic lithosphere, whereas the off-craton Proterozoic mobile belt, weakened due to a thinner lithosphere, and the presence of major pre-existing structures and thermal modification experienced short-wavelength deformation.

Due to the lack of significant preservation of post-Karoo stratigraphic units, and the overall lack of rock exposure across the plateau, direct observation of such a complex history of deformation in the geological record is difficult. The constraints provided by AFT and AHe data, presented here, on the timing, rate, and spatial distribution of denudation reveal a complex spatial and temporal Cretaceous evolution of the South African plateau (Figures 8 and 9).

We suggest that the removal of several kilometers of overburden during the Early Cretaceous from the Southwest African continental margins and off-craton region of the interior plateau was in response to the initial opening of the South Atlantic at $150-130 \mathrm{Ma}$ and the lowering of regional base levels. This response was transmitted far inland along the paleo-Orange and Vaal River systems. Long- and short-wavelength uplift triggered a younger km-scale regional phase of erosion that was particularly focused at the heavily faulted margin of the SW Kaapvaal Craton at 110-70 Ma with deformation-related uplift continuing until the early Cenozoic. However, the center of the Kaapvaal Craton studied has itself experienced extremely low amounts of cooling since the Paleozoic, suggesting that the region was not significantly buried or eroded since the Pan-African orogenic cycle. The Cenozoic erosion history of the plateau is now well-constrained by AFT, $\mathrm{AHe}$, and cosmogenic nuclide data and the preservation of crater facies rocks of Late Cretaceous kimberlites and is characterized by low erosion rates (5-15 m/Myr) with the total thickness of material removed during the Cenozoic being less than approximately $1 \mathrm{~km}$.

Acknowledgments

Full analytical details, data tables, QTQt models, and QTQt data files can be accessed through the online supporting information. We thank Olivier Datueil, Francois Guillocheau, Tim Redfield, Delphine Rouby, and Guilio Viola for insightful contributions during this project. Marco Andreoli and staff at NECSA are thanked for logistic support during fieldwork in Namaqualand. Alexandre Kounov and Jessica Stanley are sincerely thanked for their constructive and detailed reviews. This work was funded by the Natural Environment Research Council, UK, grants NE/H008276/1, NE/H008454/1, and NE/JE500252/1. The University of Melbourne thermochronology laboratory receives infrastructure support under the AuScope Program of NCRIS.

\section{References}

Altermann, W., and D. R. Nelson (1998), Sedimentation rates, basin analysis and regional correlations of three Neoarchaean and Palaeoproterozoic sub-basins of the Kaapvaal craton as inferred from precise U-Pb zircon ages from volcaniclastic sediments, Sediment. Geol., 120(1), 225-256, doi:10.1016/S0037-0738(98)00034-7.

Altermann, W., and I. W. Hälbich (1991), Structural history of the southwestern corner of the Kaapvaal Craton and the adjacent Namaqua realm: New observations and a reappraisal, Precambrian Res., 52(1), 133-166, doi:10.1016/0301-9268(91)90017-5.

Artemieva, I. M., and L. P. Vinnik (2016), Density structure of the cratonic mantle in southern Africa: 1. Implications for dynamic topography, Gondwana Res., doi:10.1016/j.gr.2016.03.002.

Ault, A. K., R. M. Flowers, and S. A. Bowring (2013), Phanerozoic surface history of the Slave craton, Tectonics, 32, 1066-1083, doi:10.1002/ tect.20069.

Bamford, M. K. (2000), Fossil woods of Karoo age deposits in South Africa and Namibia as an aid to biostratigraphical correlation, J. Afr. Earth Sci., 31(1), 119-132, doi:10.1016/S0899-5362(00)00077-4.

Baptiste, V., A. Tommasi, and S. Demouchy (2012), Deformation and hydration of the lithospheric mantle beneath the Kaapvaal craton, South Africa, Lithos, 149, 31-50, doi:10.1016/j.lithos.2012.05.001.

Bell, D. R., M. D. Schmitz, and P. E. Janney (2003), Mesozoic thermal evolution of the southern African mantle lithosphere, Lithos, 71(2), 273-287, doi:10.1016/S0024-4937(03)00117-8.

Belton, D. X., and M. J. Raab (2010), Cretaceous reactivation and intensified erosion in the Archean-Proterozoic Limpopo Belt, demonstrated by apatite fission track thermochronology, Tectonophysics, 480(1), 99-108, doi:10.1016/j.tecto.2009.09.018.

Beucher, R., R. W. Brown, S. Roper, F. Stuart, and C. Persano (2013), Natural age dispersion arising from the analysis of broken crystals: Part II. Practical application to apatite (U-Th)/He thermochronometry, Geochim. Cosmochim. Acta, 120, 395-416, doi:10.1016/j.gca.2013.05.042.

Beukes, N. J., H. S. van Niekerk, and J. Gutzmer (1999), Post Gondwana land surface and pedogenetic ferromanganese deposits on the Witwatersrand at the West Wits Gold Mine, South Africa, S. Afr. J. Geol., 102(1), 65-82.

Bierman, P. R., and M. Caffee (2001), Slow rates of rock surface erosion and sediment production across the Namib Desert and escarpment, southern Africa, Am. J. Sci., 301(4-5), 326-358, doi:10.2475/ajs.301.4-5.326.

Bierman, P. R., R. Coppersmith, K. Hanson, J. Neveling, E. W. Portenga, and D. H. Rood (2014), A cosmogenic view of erosion, relief generation, and the age of faulting in southern Africa, GSA Today, 24(9), 4-11, doi:10.1130/GSATG206A.1. 
Bishop, P. (2007), Long-term landscape evolution: linking tectonics and surface processes, Earth Surf. Processes Landforms, 32(3), 329-365, doi:10.1002/esp.1493.

Blenkinsop, T. G., and A. Moore (2013), Tectonic geomorphology of passive margins and continental hinterlands, in Treatise on Geomorphology, vol. 5, edited by J. F. Shroder, pp. 71-92, Academic Press, London, doi:10.1016/B978-0-12-374739-6.00083-X.

Brandt, M. B., S. P. Grand, A. A. Nyblade, and P. H. Dirks (2012), Upper mantle seismic structure beneath Southern Africa: Constraints on the buoyancy supporting the African superswell, Pure Appl. Geophys., 169(4), 595-614, doi:10.1007/s00024-011-0361-8.

Braun, J. (2010), The many surface expressions of mantle dynamics, Nat. Geosci., 3(12), 825-833, doi:10.1038/ngeo1020.

Braun, J., F. Guillocheau, C. Robin, G. Baby, and H. Jelsma (2014), Rapid erosion of the Southern African Plateau as it climbs over a mantle superswell, J. Geophys. Res. Solid Earth, 119, 6093-6112, doi:10.1002/2014JB010998..

Brown, L. F., J. M. Benson, G. J. Brink, S. Doherty, A. Jollands, E. H. A. Jungslager, J. H. G. Keenan, A. Muntingh, and N. J. S. van Wyk (1995), Sequence Stratigraphy in Offshore South African Divergent Basins: An Atlas on Exploration for Cretaceous Lowstand Traps by Soekor (Pty) Ltd, AAPG Stud. in Geol., 41, AAPG, doi:10.1306/St41600.

Brown, R. W., M. A. Summerfield, and A. J. Gleadow (2002), Denudational history along a transect across the Drakensberg Escarpment of southern Africa derived from apatite fission track thermochronology, J. Geophys. Res., 107(B12), 2350, doi:10.1029/2001JB000745.

Brown, R. W., R. Beucher, S. Roper, C. Persano, F. Stuart, and P. Fitzgerald (2013), Natural age dispersion arising from the analysis of broken crystals. Part I: Theoretical basis and implications for the apatite (U-Th)/He thermochronometer, Geochim. Cosmochim. Acta, 122, 478-497, doi:10.1016/j.gca.2013.05.041.

Brown, R., K. Gallagher, and M. Duane (1994), A quantitative assessment of the effects of magmatism on the thermal history of the Karoo sedimentary sequence, J. Afr. Earth Sci., 18(3), 227-243.

Brown, R., M. Summerfield, A. Gleadow, K. Gallagher, A. Carter, R. Beucher, and M. Wildman (2014), Intracontinental deformation in southern Africa during the Late Cretaceous, J. Afr. Earth Sci., 100, 20-41, doi:10.1016/j.jafrearsci.2014.05.014.

Burke, K. (1996), The African plate, S. Afr. J. Geol., 99(4), 341-409.

Burke, K., and Y. Gunnell (2008), The African erosion surface: a continental-scale synthesis of geomorphology, tectonics, and environmental change over the past 180 million years, Geol. Soc. Am. Mem., 201, 1-66, doi:10.1130/2008.1201.

Burov, E., and S. Cloetingh (2009), Controls of mantle plumes and lithospheric folding on modes of intraplate continental tectonics: Differences and similarities, Geophys. J. Int., 178(3), 1691-1722.

Burov, E., and T. Gerya (2014), Asymmetric three-dimensional topography over mantle plumes, Nature, 513(7516), 85-89, doi:10.1038/ nature13703.

Burov, E., and L. Guillou-Frottier (2005), The plume head-continental lithosphere interaction using a tectonically realistic formulation for the lithosphere, Geophys. J. Int., 161(2), 469-490, doi:10.1016/j.tecto.2007.01.002.

Calignano, E., D. Sokoutis, E. Willingshofer, F. Gueydan, and S. Cloetingh (2015), Strain localization at the margins of strong lithospheric domains: Insights from analog models, Tectonics, 34, 396-412, doi:10.1002/2014TC003756.

Carlson, W. D., R. A. Donelick, and R. A. Ketcham (1999), Variability of apatite fission-track annealing kinetics: I. Experimental results, Am. Mineral., 84(9), 1213-1223, doi:10.2138/am-1999-0901.

Catuneanu, O., H. Wopfner, P. G. Eriksson, B. Cairncross, B. S. Rubidge, R. M. H. Smith, and P. J. Hancox (2005), The Karoo basins of southcentral Africa, J. Afr. Earth Sci., 43(1), 211-253, doi:10.1016/j.jafrearsci.2005.07.007.

Chardon, D., J. L. Grimaud, D. Rouby, A. Beauvais, and F. Christophoul (2016), Stabilization of large drainage basins over geological time scales: Cenozoic West Africa, hot spot swell growth, and the Niger River, Geochem. Geophys. Geosyst., $17,1164$.

Christie-Blick, N., and K. T. Biddle (1985), Deformation and sedimentation along strike-slip faults, in Strike-Slip Deformation, Basin Formation and Sedimentation, edited by K. T. Biddle and N. Christie-Blick, pp. 1-37, SEPM Special Publications, Tulsa, Okla.

Clark, M. K., K. A. Farley, D. Zheng, Z. Wang, and A. R. Duvall (2010), Early Cenozoic faulting of the northern Tibetan Plateau margin from apatite (U-Th)/He ages, Earth Planet. Sci. Lett., 296(1), 78-88, doi:10.1016/j.epsl.2010.04.051.

Clemson, J., J. Cartwright, and J. Booth (1997), Structural segmentation and the influence of basement structure on the Namibian passive margin, J. Geol. Soc., 154(3), 477-482, doi:10.1144/gsjgs.154.3.0477.

Cloetingh, S., and E. Burov (2011), Lithospheric folding and sedimentary basin evolution: A review and analysis of formation mechanisms, Basin Res., 23(3), 257-290.

Cloetingh, S., E. Burov, and T. Francois (2013), Thermo-mechanical controls on intra-plate deformation and the role of plume-folding interactions in continental topography, Gondwana Res., 24(3), 815-837, doi:10.1111/j.1365-2117.2010.00490.x.

Cockburn, H. A. P., R. W. Brown, M. A. Summerfield, and M. A. Seidl (2000), Quantifying passive margin denudation and landscape development using a combined fission-track thermochronology and cosmogenic isotope analysis approach, Earth Planet. Sci. Lett., 179(3), 429-435, doi:10.1016/s0012-821x(00)00144-8.

Codilean, A. T., P. Bishop, F. M. Stuart, T. B. Hoey, D. Fabel, and S. P. Freeman (2008), Single-grain cosmogenic $21 \mathrm{Ne}$ concentrations in fluvial sediments reveal spatially variable erosion rates, Geology, 36(2), 159-162, doi:10.1130/g24360a.1.

Codilean, A. T., C. R. Fenton, D. Fabel, P. Bishop, and S. Xu (2014), Discordance between cosmogenic nuclide concentrations in amalgamated sands and individual fluvial pebbles in an arid zone catchment, Quat. Geochronol., 19, 173-180, doi:10.1016/j.quageo.2012.04.007.

Cogné, N., K. Gallagher, and P. R. Cobbold (2011), Post-rift reactivation of the onshore margin of southeast Brazil: Evidence from apatite (U-Th)/He and fission-track data, Earth Planet. Sci. Lett., 309(1), 118-130, doi:10.1016/j.epsl.2011.06.025.

Cogné, N., K. Gallagher, P. R. Cobbold, C. Riccomini, and C. Gautheron (2012), Post-breakup tectonics in southeast Brazil from thermochronological data and combined inverse-forward thermal history modeling, J. Geophys. Res., 117, B11413, doi:10.1029/ 2012JB009340.

Colli, L., I. Stotz, H. P. Bunge, M. Smethurst, S. Clark, G. laffaldano, A. Tassara, F. Guillocheau, and M. C. Bianchi (2014), Rapid South Atlantic spreading changes and coeval vertical motion in surrounding continents: Evidence for temporal changes of pressure-driven upper mantle flow, Tectonics, 33, 1304-1321, doi:10.1002/2014TC003612.

Colli, L., S. Ghelichkhan, and H. P. Bunge (2016), On the ratio of dynamic topography and gravity anomalies in a dynamic Earth, Geophys. Res. Lett., 43, 2510-2516, doi:10.1002/2016GL067929.

Colliston, W. P., and A. E. Schoch (2013), Wrench-shearing during the Namaqua Orogenesis-Mesoproterozoic late stage deformation effects during Rodinia assembly, Precambrian Res., 233, 44-58, doi:10.1016/j.precamres.2013.03.007.

Colliston, W. P., D. H. Cornell, A. E. Schoch, and H. E. Praekelt (2015), Geochronological constraints on the Hartbees River Thrust and Augrabies Nappe: New insights into the assembly of the Mesoproterozoic Namaqua-Natal Province of Southern Africa, Precambrian Res., 265, 150-165, doi:10.1016/j.precamres.2015.03.008.

Cornelissen, A. K., and W. J. Verwoerd (1975), The Bushmanland kimberlites and related rocks, Phys. Chem. Earth, 9, 71-80, doi:10.1016/b9780-08-018017-5.50011-0. 
Cornell, D. H., R. J. Thomas, R. Gibson, H. F. G. Moen, D. L. Reid, J. M. Moore, and R. L. Gibson (2006), The Namaqua-Natal Province, Geol. Soc. S. Afr., 325-379, isbn:9781919908779.

Cox, K. G. (1992), Karoo igneous activity, and the early stages of the break-up of Gondwanaland, Geol. Soc. London, Spec. Publ., 68(1), 137-148, doi:10.1144/GSL.SP.1992.068.01.09.

Daly, M. C., J. Chorowicz, and J. D. Fairhead (1989), Rift basin evolution in Africa: The influence of reactivated steep basement shear zones, Geol. Soc. London, Spec. Publ., 44(1), 309-334, doi:10.1144/gsl.sp.1989.044.01.17.

Dauteuil, O., F. Deschamps, O. Bourgeois, A. Mocquet, and F. Guillocheau (2013), Post-breakup evolution and palaeotopography of the North Namibian Margin during the Meso-Cenozoic, Tectonophysics, 589, 103-115, doi:10.1016/j.tecto.2012.12.022.

de Beer, C. H. (2012), Evidence of Neogene to Quaternary faulting and seismogenic deformation along the Namaqualand coast, South Africa, S. Afr. J. Geol., 115(2), 117-136, doi:10.2113/gssajg.115.2.117.

de Vera, J., P. Granado, and K. McClay (2010), Structural evolution of the Orange Basin gravity-driven system, offshore Namibia, Mar. Pet. Geol., 27(1), 223-237, doi:10.1016/j.marpetgeo.2009.02.003.

De Wit, M. (2007), The Kalahari Epeirogeny and climate change: Differentiating cause and effect from core to space, S. Afr. J. Geol., 110(2-3), 367-392, doi:10.2113/gssajg.110.2-3.367.

de Wit, M. C. (2016), Dwyka Eskers Along the Northern Margin of the Main Karoo Basin, in Origin and Evolution of the Cape Mountains and Karoo Basin, pp. 87-99, Springer Int.

de Wit, M. C. J. (1988), Aspects of the geomorphology of the north-western Cape, South Africa, in Geomorphological Studies in Southern Africa, edited by G. F. Dardis and B. P. Moon, pp. 57-69, CRC Press, Rotterdam, Netherlands.

de Wit, M. C. J. (1999), Post-Gondwana drainage and the development of diamond placers in western South Africa, Econ. Geol., 94(5), 721-740, doi:10.2113/gsecongeo.94.5.721.

de Wit, M. C. J., J. D. Ward, M. K. Bamford, and M. J. Roberts (2009), The significance of the Cretaceous diamondiferous gravel deposit at Mahura Muthla, Northern Cape province, South Africa, S. Afr. J. Geol., 112(2), 89-108, doi:10.2113/gssajg.112.2.89.

Decker, J. E., S. Niedermann, and M. J. de Wit (2011), Soil erosion rates in South Africa compared with cosmogenic 3 He-based rates of soil production, S. Afr. J. Geol., 114(3-4), 475-488, doi:10.2113/gssajg.114.3-4.475.

Delph, J. R., and R. C. Porter (2015), Crustal structure beneath Southern Africa: Insight into how tectonic events affect the Mohorovičić discontinuity, Geophys. Journal Int., 200(1), 254-264, doi:10.1093/gji/ggu376.

Dewey, J. F., L. Robb, and L. Van Schalkwyk (2006), Did Bushmanland extensionally unroof Namaqualand?, Precambrian Res., 150(3), 173-182, doi:10.1016/j.precamres.2006.07.007.

Dingle, R. V., W. G. Siesser, and A. R. Newton (1983), Mesozoic and Tertiary Geology of Southern Africa, Balkema, Rotterdam.

Dixey, F. (1955), Erosion surfaces in Africa: Some considerations of age and origin, Trans. Geol/. Society South Africa, 58, $265-280$.

Dollar, E. S. (1998), Palaeofluvial geomorphology in southern Africa: A review, Prog. Phys. Geogr., 22(3), 325-349, doi:10.1177/ 030913339802200302.

Donelick, R. A., P. B. O'Sullivan, and R. A. Ketcham (2005), Apatite fission-track analysis, Rev. Mineral. Geochem., 58(1), 49-94, doi:10.2138/ rmg.2005.58.3.

Duncan, R. A., P. R. Hooper, J. Rehacek, J. S. Marsh, and A. R. Duncan (1997), The timing and duration of the Karoo igneous event, southern Gondwana, J. Geophys. Res., 102, 18,127-18,138, doi:10.1029/97JB00972.

Dunkl, I. (2002), TRACKKEY: A Windows program for calculation and graphical presentation of fission track data, Comput. Geosci., 28(1), 3-12 doi:10.1016/s0098-3004(01)00024-3.

Duvall, A. R., M. K. Clark, B. A. van der Pluijm, and C. Li (2011), Direct dating of Eocene reverse faulting in northeastern Tibet using Ar-dating of fault clays and low-temperature thermochronometry, Earth Planet. Sci. Lett., 304(3), 520-526.

Eagles, G. (2007), New angles on South Atlantic opening, Geophys. J. Int., 168(1), 353-361, doi:10.1111/j.1365-246x.2006.03206.x.

Eglington, B. M. (2006), Evolution of the Namaqua-Natal Belt, southern Africa-A geochronological and isotope geochemical review, J. Afr. Earth Sci., 46(1), 93-111, doi:10.1016/j.jafrearsci.2006.01.014.

Eriksson, P. G., W. Altermann, and F. J. Hartzer (2006), The Transvaal Supergroup and its precursors, The Geology of South Africa. Geological Society of South Africa, Johannesburg/Council for Geoscience, Pretoria, 237-260.

Erlanger, E. D., D. E. Granger, and R. J. Gibbon (2012), Rock uplift rates in South Africa from isochron burial dating of fluvial and marine terraces, Geology, 40(11), 1019-1022, doi:10.1130/g33172.1.

Fairhead, J. D., C. M. Green, S. M. Masterton, and R. Guiraud (2013), The role that plate tectonics, inferred stress changes and stratigraphic unconformities have on the evolution of the West and Central African Rift System and the Atlantic continental margins, Tectonophysics, 594, 118-127, doi:10.1016/j.tecto.2013.03.021.

Farley, K. A., R. A. Wolf, and L. T. Silver (1996), The effects of long alpha-stopping distances on (U-Th)/He ages, Geochim. Cosmochim. Acta, 60(21), 4223-4229, doi:10.1016/s0016-7037(96)00193-7.

Farley, K. A., D. L. Shuster, and R. A. Ketcham (2011), U and Th zonation in apatite observed by laser ablation ICPMS, and implications for the (U-Th)/He system, Geochim. Cosmochim. Acta, 75(16), 4515-4530, doi:10.1016/j.gca.2011.05.020.

Fishwick, S., and I. D. Bastow (2011), Towards a better understanding of African topography: A review of passive-source seismic studies of the African crust and upper mantle, Geol. Soc. London, Spec. Publ., 357(1), 343-371, doi:10.1144/SP357.19.

Fitzgerald, P. G., S. L. Baldwin, L. E. Webb, and P. B. O'sullivan (2006), Interpretation of (U-Th)/He single grain ages from slowly cooled crustal terranes: A case study from the Transantarctic Mountains of southern Victoria Land, Chem. Geol., 225(1), 91-120, doi:10.1016/j. chemgeo.2005.09.001.

Flament, N., M. Gurnis, S. Williams, M. Seton, J. Skogseid, C. Heine, and R. D. Müller (2014), Topographic asymmetry of the South Atlantic from global models of mantle flow and lithospheric stretching, Earth Planet. Sci. Lett., 387, 107-119, doi:10.1016/j.epsl.2013.11.017.

Fleming, A., M. A. Summerfield, J. O. Stone, L. K. Fifield, and R. G. Cresswell (1999), Denudation rates for the southern Drakensberg Escarpment, SE Africa, derived from in-situ-produced cosmogenic 36Cl: Initial results, J. Geol. Soc., 156(2), 209-212, doi:10.1144/ gsjgs.156.2.0209.

Flowers, R. M., and B. Schoene (2010), (U-Th)/He thermochronometry constraints on unroofing of the eastern Kaapvaal craton and significance for uplift of the southern African Plateau, Geology, 38(9), 827-830.

Flowers, R. M., R. A. Ketcham, D. L. Shuster, and K. A. Farley (2009), Apatite (U-Th)/He thermochronometry using a radiation damage accumulation and annealing model, Geochim. Cosmochim. Acta, 73(8), 2347-2365.

Foeken, J., F. M. Stuart, K. J. Dobson, C. Persano, and D. Vilbert (2006), A diode laser system for heating minerals for (U-Th)/He chronometry, Geochem. Geophys. Geosystems, 7, Q04015, doi:10.1029/2005GC001190.

Fossen, H., and B. Tikoff (1998), Extended models of transpression and transtension, and application to tectonic settings, Geol. Soc. London, Spec. Publ., 135(1), 15-33, doi:10.1144/GSL.SP.1998.135.01.02. 
Forte, A. M., R. Moucha, N. A. Simmons, S. P. Grand, and J. X. Mitrovica (2010), Deep-mantle contributions to the surface dynamics of the North American continent, Tectonophysics, 481(1), 3-15, doi:10.1016/j.gca.2009.01.015.

Fourie, C. J. S., and P. Cole (1997), Geological map of the Republic of South Africa and the Kingdoms of Lesotho and Swaziland, Council for Geoscience.

Gaina, C., T. H. Torsvik, D. J. van Hinsbergen, S. Medvedev, S. C. Werner, and C. Labails (2013), The African Plate: A history of oceanic crust accretion and subduction since the Jurassic, Tectonophysics, 604, 4-25, doi:10.1016/j.tecto.2013.05.037.

Galbraith, R. F. (2010), Statistics for Fission Track Analysis, pp. 240, Chapman and Hall/CRC, Florida.

Gallagher, K. (2012), Transdimensional inverse thermal history modeling for quantitative thermochronology, J. Geophys. Res., 117, B02408, doi:10.1029/2011JB008825.

Gallagher, K., and R. Brown (1997), The onshore record of passive margin evolution, J. Geol. Soc., 154(3), 451-457, doi:10.1144/ gsjgs.154.3.0451.

Gallagher, K., and R. Brown (1999), Denudation and uplift at passive margins: The record on the Atlantic Margin of southern Africa, Phil. Trans. R. Soc. Lond. Math. Phys. Eng. Sci., 357(1753), 835-859.

Gallagher, K., R. Brown, and C. Johnson (1998), Fission track analysis and its applications to geological problems, Annu. Rev. Earth Planet. Sci., 26(1), 519-572.

Gallagher, K., K. Charvin, S. Nielsen, M. Sambridge, and J. Stephenson (2009), Markov chain Monte Carlo (MCMC) sampling methods to determine optimal models, model resolution and model choice for Earth science problems, Mar. Pet. Geol., 26(4), 525-535, doi:10.1016/j. marpetgeo.2009.01.003.

Ganerød, M., T. H. Torsvik, D. J. J. Van Hinsbergen, C. Gaina, F. Corfu, S. Werner, T. M. Owen-Smith, L. D. Ashwal, S. J. Webb, and B. W. H. Hendriks (2011), Palaeoposition of the Seychelles microcontinent in relation to the Deccan Traps and the Plume Generation Zone in Late Cretaceous-Early Palaeogene time, Geol. Soc. London, Spec. Publ., 357(1), 229-252, doi:10.1144/SP357.12.

García-Castellanos, D., and S. I. E. R. D. Cloetingh (2011), Modeling the interaction between lithospheric and surface processes in foreland basins, in Tectonics of Sedimentary Basins: Recent Advances, edited by C. Busby and A. Azor, pp. 152-181, John Wiley, Chichester, U. K., doi:10.1002/9781444347166.ch8.

Gautheron, C., L. Tassan-Got, J. Barbarand, and M. Pagel (2009), Effect of alpha-damage annealing on apatite (U-Th)/He thermochronology Chem. Geol., 266(3), 157-170, doi:10.1016/j.chemgeo.2009.06.001.

Gautheron, C., L. Tassan-Got, R. A. Ketcham, and K. J. Dobson (2012), Accounting for long alpha-particle stopping distances in (U-Th-Sm)/He geochronology: 3D modeling of diffusion, zoning, implantation, and abrasion, Geochim. Cosmochim. Acta, 96, 44-56.

Gautheron, C., J. Barbarand, R. A. Ketcham, L. Tassan-Got, P. van der Beek, M. Pagel, R. Pinna-Jamme, F. Couffignal, and M. Fialin (2013), Chemical influence on $\alpha$-recoil damage annealing in apatite: Implications for (U-Th)/He dating, Chem. Geol., 351, 257-267, doi:10.1016/j. chemgeo.2013.05.027

Gerin, C., C. Gautheron, E. Oliviero, C. Bachelet, D. M. Djimbi, A. M. Seydoux-Guillaume, L. Tassan-Got, P. Sarda, J. Roques, and F. Garrido (2017), Influence of vacancy damage on He diffusion in apatite, investigated at atomic to mineralogical scales, Geochim. Cosmochim. Acta, 197, 87-103.

Gilchrist, A. R., and M. A. Summerfield (1990), Differential denudation and flexural isostasy in formation of rifted-margin upwarps, 346, 739-742, doi:10.1038/346739a0.

Gilchrist, A. R., H. Kooi, and C. Beaumont (1994), Post-Gondwana geomorphic evolution of southwestern Africa: Implications for the controls on landscape development from observations and numerical experiments, J. Geophys. Res., 99, 12,211-12,228, doi:10.1029/94JB00046

Gleadow, A., M. Harrison, B. Kohn, R. Lugo-Zazueta, and D. Phillips (2015), The Fish Canyon Tuff: A new look at an old low-temperature thermochronology standard, Earth Planet. Sci. Lett., 424, 95-108.

Gleadow, A. J. W., and P. G. Fitzgerald (1987), Uplift history and structure of the Transantarctic Mountains: New evidence from fission track dating of basement apatites in the Dry Valleys area, southern Victoria Land, Earth Planet. Sci. Lett., 82(1), 1-14.

Gorczyk, W., and K. Vogt (2015), Tectonics and melting in intra-continental settings, Gondwana Res., 27(1), 196-208, doi:10.1016/j. gr.2013.09.021

Goudie, A. S. (2005), The drainage of Africa since the Cretaceous, Geomorphology, 67(3), 437-456, doi:10.1016/j.geomorph.2004.11.008.

Granot, R., and J. Dyment (2015), The Cretaceous opening of the South Atlantic Ocean, Earth Planet. Sci. Lett., 414, 156-163, doi:10.1016/j. epsl.2015.01.015.

Green, P. F., I. R. Duddy, A. J. W. Gleadow, P. R. Tingate, and G. M. Laslett (1985), Fission-track annealing in apatite: Track length measurements and the form of the Arrhenius plot, Nucl. Tracks Radiat. Meas., 10(3), 323-328.

Green, P. F., I. R. Duddy, A. J. W. Gleadow, P. R. Tingate, and G. M. Laslett (1986), Thermal annealing of fission tracks in apatite: 1. A qualitative description, Chem. Geol. Isot. Geosci. Sect., 59, 237-253.

Green, P. F., I. R. Duddy, G. M. Laslett, K. A. Hegarty, A. W. Gleadow, and J. F. Lovering (1989), Thermal annealing of fission tracks in apatite 4. Quantitative modelling techniques and extension to geological timescales, Chem. Geol. Isot. Geosci. Sect., 79(2), 155-182, doi:10.1016/ 0168-9622(89)90018-3.

Green, P. F., P. V. Crowhurst, I. R. Duddy, P. Japsen, and S. P. Holford (2006), Conflicting (U-Th)/He and fission track ages in apatite: Enhanced He retention, not anomalous annealing behaviour, Earth Planet. Sci. Lett., 250(3), 407-427, doi:10.1016/j.epsl.2006.08.022.

Green, P. F., K. Lidmar-Bergström, P. Japsen, J. M. Bonow, and J. A. Chalmers (2013), Stratigraphic landscape analysis, thermochronology and the episodic development of elevated, passive continental margins, Geological Survey of Denmark and Greenland. Danish Ministry of climate, energy and building, isbn:978-87-7871-372-8.

Green, P. F., I. R. Duddy, P. Japsen, J. M. Bonow, and J. A. Malan (2016), Post-breakup burial and exhumation of the southern margin of Africa, Basin Res., doi:10.1111/bre.12167.

Gresse, P. G., and G. J. B. Germs (1993), The Nama foreland basin: Sedimentation, major unconformity bounded sequences and multisided active margin advance, Precambrian Res., 63(3), 247-272, doi:10.1016/0301-9268(93)90036-2.

Gresse, P. G., M. W. Von Veh, and H. E. Frimmel (2006), Namibian (Neoproterozoic) to early Cambrian successions, in The Geology of South Africa, edited by C. R. Johannesburg and R. J. Thomas, pp. 395-420, Geological Society of South Africa, Pretoria, isbn:9781919908779.

Griffin, W. L., S. Y. O'Reilly, L. M. Natapov, and C. G. Ryan (2003), The evolution of lithospheric mantle beneath the Kalahari Craton and its margins, Lithos, 71(2), 215-241, doi:10.1016/j.lithos.2003.07.006.

Griffin, W. L., S. Y. O'reilly, J. C. Afonso, and G. C. Begg (2009), The composition and evolution of lithospheric mantle: A re-evaluation and its tectonic implications, J. Petrol., 50(7), 1185-1204.

Gueydan, F., J. Précigout, and L. G. Montesi (2014), Strain weakening enables continental plate tectonics, Tectonophysics, 631, 189-196, doi:10.1016/j.tecto.2014.02.005. 
Guillaume, B., C. Gautheron, T. Simon-Labric, J. Martinod, M. Roddaz, and E. Douville (2013), Dynamic topography control on Patagonian relief evolution as inferred from low temperature thermochronology, Earth Planet. Sci. Lett., 364, 157-167, doi:10.1016/j.epsl.2012.12.036

Guillocheau, F., D. Rouby, C. Robin, C. Helm, N. Rolland, C. Le Carlier de Veslud, and J. Braun (2012), Quantification and causes of the terrigenous sediment budget at the scale of a continental margin: A new method applied to the Namibia-South Africa margin, Basin Res., 24(1), 3-30, doi:10.1111/j.1365-2117.2011.00511.x.

Guillou-Frottier, L., E. Burov, S. Cloetingh, E. Le Goff, Y. Deschamps, B. Huet, and V. Bouchot (2012), Plume-induced dynamic instabilities near cratonic blocks: Implications for P-T-t paths and metallogeny, Global Planet. Change, 90, 37-50, doi:10.1016/j.gloplacha.2011.10.007.

Gunnell, Y., K. Gallagher, A. Carter, M. Widdowson, and A. J. Hurford (2003), Denudation history of the continental margin of western peninsular India since the early Mesozoic-Reconciling apatite fission-track data with geomorphology, Earth Planet. Sci. Lett., 215(1), 187-201, doi:10.1016/s0012-821x(03)00380-7.

Guiraud, R., and W. Bosworth (1997), Senonian basin inversion and rejuvenation of rifting in Africa and Arabia: Synthesis and implications to plate-scale tectonics, Tectonophysics, 282(1), 39-82, doi:10.1016/S0040-1951(97)00212-6.

Gurnis, M., J. X. Mitrovica, J. Ritsema, and H. J. van Heijst (2000), Constraining mantle density structure using geological evidence of surface uplift rates: The case of the African superplume, Geochem. Geophys. Geosyst., 1, 1020, doi:10.1029/1999GC000035.

Gutzmer, J., and N. J. Beukes (2000), Asbestiform manjiroite and todorokite from the Kalahari manganese field, South Africa, S. Afr. J. Geol., 103(3-4), 163-174, doi:10.2113/1030163.

Haddon, I. G., and T. S. McCarthy (2005), The Mesozoic-Cenozoic interior sag basins of Central Africa: The Late-Cretaceous-Cenozoic Kalahari and Okavango basins, J. Afr. Earth Sci., 43(1), 316-333, doi:10.1016/j.jafrearsci.2005.07.008.

Hanson, E. K., J. M. Moore, E. M. Bordy, J. S. Marsh, G. Howarth, and J. V. A. Robey (2009), Cretaceous erosion in central South Africa: Evidence from upper-crustal xenoliths in kimberlite diatremes, S. Afr. J. Geol., 112, 125-140, doi:10.2113/gssajg.112.2.125.

Heine, C., J. Zoethout, and R. D. Müller (2013), Kinematics of the South Atlantic rift, Solid Earth, 4, 215-253, doi:10.5194/se-4-215-2013.

Herbert, C. T., and J. S. Compton (2007), Depositional environments of the Lower Permian Dwyka diamictite and Prince Albert shale inferred from the geochemistry of early diagenetic concretions, southwest Karoo Basin, South Africa, Sediment. Geol., 194(3), 263-277, doi:10.1016/ j.sedgeo.2006.06.008.

Herman, F., J. Braun, T. J. Senden, and W. J. Dunlap (2007), (U-Th)/He thermochronometry: Mapping 3D geometry using micro-X-ray tomography and solving the associated production-diffusion equation, Chem. Geol., 242(1), 126-136.

Hurford, A. J., and P. F. Green (1982), A users' guide to fission track dating calibration, Earth Planet. Sci. Lett., 59(2), 343-354, doi:10.1016/0012$821 \times(82) 90136-4$

Jacob, R. J., B. J. Bluck, and J. D. Ward (1999), Tertiary-age diamondiferous fluid deposits of the lower Orange River valley, Southwest Africa, Econ. Geol., 94(5), 749-758, doi:10.2113/gsecongeo.94.5.749.

Jacobs, J., R. J. Thomas, and K. Weber (1993), Accretion and indentation tectonics at the southern edge of the Kaapvaal Craton during the Kibaran (Grenville) orogeny, Geology, 21(3), 203-206, doi:10.1130/0091-7613(1993)021<0203:aaitat>2.3.co;2.

Janney, P. E., S. B. Shirey, R. W. Carlson, D. G. Pearson, D. R. Bell, A. P. Le Roex, A. Ishikawa, P. H. Nixon, and F. R. Boyd (2010), Age, composition and thermal characteristics of South African off-craton mantle lithosphere: Evidence for a multi-stage history, J. Petrol., doi:10.1093/petrology/egq041.

Janssen, M. E., R. A. Stephenson, and S. A. P. L. Cloetingh (1995), Temporal and spatial correlations between changes in plate motions and the evolution of rifted basins in Africa, Geol. Soc. Am. Bull., 107(11), 1317-1332, doi:10.1130/0016-7606(1995)107<1317:TASCBC>2.3.CO;2

Jelsma, H., W. Barnett, S. Richards, and G. Lister (2009), Tectonic setting of kimberlites, Lithos, 112, 155-165, doi:10.1016/j.lithos.2009.06.030.

Johnson, M. R., C. R. Anhauesser, and R. J. Thomas (2006), The Geology of South Africa, Geological Society of South Africa, Pretoria, isbn:9781919908779.

Jones, M. Q. W. (1987), Heat flow and heat production in the Namaqua mobile belt, South Africa, J. Geophys. Res., 92, 6273-6289, doi:10.1029/ JB092ib07p06273.

Jourdan, F., G. Féraud, H. Bertrand, A. B. Kampunzu, G. Tshoso, M. K. Watkeys, and B. Le Gall (2005), Karoo large igneous province: Brevity, origin, and relation to mass extinction questioned by new 40Ar/39Ar age data, Geology, 33(9), 745-748, doi:10.1130/g21632.1.

Jourdan, F., G. Féraud, H. Bertrand, and M. K. Watkeys (2007), From flood basalts to the inception of oceanization: Example from the 40Ar/39Ar high-resolution picture of the Karoo large igneous province, Geochem. Geophys. Geosyst., 8, Q02002, doi:10.1029/ 2006 GC001392.

Karlstrom, K. E., and E. D. Humphreys (1998), Persistent influence of Proterozoic accretionary boundaries in the tectonic evolution of southwestern North America interaction of cratonic grain and mantle modification events, Rocky Mt. Geol., 33(2), 161-179, doi:10.2113/33.2.161.

Kendall, B., D. van Acken, and R. A. Creaser (2013), Depositional age of the early paleoproterozoic klipputs member, nelani formation (Ghaap Group, Transvaal Supergroup, South Africa) and implications for low-level Re-Os geochronology and paleoproterozoic global correlations, Precambrian Res., 237, 1-12, doi:10.1016/j.precamres.2013.08.002

Ketcham, R. A. (2005), The role of crystallographic angle in characterizing and modeling apatite fission-track length data, Radiat. Meas., 39(6), 595-601, doi:10.1016/j.radmeas.2004.07.008.

Ketcham, R. A., A. Carter, R. A. Donelick, J. Barbarand, and A. J. Hurford (2007), Improved modeling of fission-track annealing in apatite, Am. Mineral., 92(5-6), 799-810, doi:10.2138/am.2007.2281.

Ketcham, R. A., W. R. Guenthner, and P. W. Reiners (2013), Geometric analysis of radiation damage connectivity in zircon, and its implications for helium diffusion, Am. Mineral., 98(2-3), 350-360.

King, L. C. (1955), Pediplanation and isostasy: An example from South Africa, Quart. J. Geol. Soc., 111(1-4), 353-359, doi:10.1144/GSL. JGS.1955.111.01-04.18.

Kobussen, A. F., W. L. Griffin, S. Y. O'Reilly, and S. R. Shee (2008), Ghosts of lithospheres past: Imaging an evolving lithospheric mantle in Southern Africa, Geology, 36(7), 515-518, doi:10.1130/G24868A.1.

Kohn, B. P., M. Lorencak, A. J. Gleadow, F. Kohlmann, A. Raza, K. G. Osadetz, and P. Sorjonen-Ward (2009), A reappraisal of low-temperature thermochronology of the eastern Fennoscandia Shield and radiation-enhanced apatite fission-track annealing, Geol. Soc. London, Spec. Publ., 324(1), 193-216.

Koptev, A., E. Calais, E. Burov, S. Leroy, and T. Gerya (2015), Dual continental rift systems generated by plume-lithosphere interaction, Nat Geosci., 8(5), 388-392, doi:10.1038/ngeo2401.

Kounov, A., S. Niedermann, M. J. de Wit, G. Viola, M. Andreoli, and J. Erzinger (2007), Present denudation rates at selected sections of the South African escarpment and the elevated continental interior based on cosmogenic 3He and 21Ne, S. Afr. J. Geol., 110(2-3), 235-248, doi:10.2113/gssajg.110.2-3.235.

Kounov, A., G. Viola, M. DeWit, and M. A. G. Andreoli (2009), Denudation along the Atlantic passive margin: New insights from apatite fissiontrack analysis on the western coast of South Africa, Geol. Soc. London, Spec. Publ., 324(1), 287-306, doi:10.1144/sp324.19. 
Kounov, A., G. Viola, I. Dunkl, and H. E. Frimmel (2013), Southern African perspectives on the long-term morpho-tectonic evolution of cratonic interiors, Tectonophysics, 601, 177-191, doi:10.1016/j.tecto.2013.05.009.

Kounov, A., S. Niedermann, M. J. de Wit, A. T. Codilean, G. Viola, M. Andreoli, and M. Christl (2015), Cosmogenic $21 \mathrm{Ne}$ and $10 \mathrm{Be}$ reveal a more than 2 Ma alluvial fan flanking the Cape Mountains, South Africa, S. Afr. J. Geol., 118(2), 129-144, doi:10.2113/gssajg.118.2.129.

Labails, C., T. H. Torsvik, C. Gaina, and R. M. Cocks (2009), Global plate polygons 2009. SPlates Model (version 2.0), Tech. Rep. 2009.047, NGU, Postboks 6315 Sluppen, 7491 Trondheim. [Available at http://www.ngu.no/en-gb/.]

Lenardic, A., L. Moresi, and H. Mühlhaus (2000), The role of mobile belts for the longevity of deep cratonic lithosphere: The crumple zone model, Geophys. Res. Lett., 27, 1235-1238, doi:10.1029/1999GL008410.

Lenardic, A., L. N. Moresi, and H. Mühlhaus (2003), Longevity and stability of cratonic lithosphere: Insights from numerical simulations of coupled mantle convection and continental tectonics, J. Geophys. Res., 108(B6), 2302, doi:10.1029/2001JB000169.

Leprêtre, R., Y. Missenard, J. Barbarand, C. Gautheron, O. Saddiqi, and R. Pinna-Jamme (2015), Postrift history of the eastern central Atlantic passive margin: Insights from the Saharan region of South Morocco, J. Geophys. Res. Solid Earth, 120, 4645-4666, doi:10.1002/2014JB011549.

Lisker, F., B. Ventura, and U. A. Glasmacher (2009), Apatite thermochronology in modern geology, Geol. Soc. London, Spec. Publ., 324(1), 1-23.

Lithgow-Bertelloni, C., and P. G. Silver (1998), Dynamic topography, plate driving forces and the African superswell, Nature, 395(6699), 269-272, doi:10.1038/26212

Mbongo-Djimbi, D., C. Gautheron, J. Roques, L. Tassan-Got, C. Gerin, and E. Simoni (2015), Impact of apatite chemical composition on (U-Th)/ He thermochronometry: An atomistic point of view, Geochim. Cosmochim. Acta, 167, 162-176, doi:10.1016/j.gca.2015.06.017.

McMillan, I. K. (2003), Foraminiferally defined biostratigraphic episodes and sedimentation pattern of the Cretaceous drift succession (Early Barremian to Late Maastrichtian) in seven basins on the South African and southern Namibian continental margin, S. Afr. J. Sci., 99(11 \& 12), 537, issn:00382353.

Meesters, A. G. C. A., and T. J. Dunai (2002a), Solving the production-diffusion equation for finite diffusion domains of various shapes: Part I. Implications for low-temperature (U-Th)/He thermochronology, Chem. Geol., 186(3), 333-344, doi:10.1016/s0009-2541(01)00422-3.

Meesters, A. G. C. A., and T. J. Dunai (2002b), Solving the production-diffusion equation for finite diffusion domains of various shapes: Part II. Application to cases with $\alpha$-ejection and nonhomogeneous distribution of the source, Chem. Geol., 186(3), 347-363, doi:10.1016/s00092541(02)00073-6.

Molnar, P., P. C. England, and C. H. Jones (2015), Mantle dynamics, isostasy, and the support of high terrain, J. Geophys. Res. Solid Earth, 120, 1932-1957, doi:10.1002/2014JB011724

Moore, A. E., and P. A. Larkin (2001), Drainage evolution in south-central Africa since the breakup of Gondwana, S. Afr. J. Geol., 104(1), 47-68, doi:10.2113/104.1.47.

Moore, A. E., and W. J. Verwoerd (1985), The olivine melilitite-"kimberlite"-carbonatite suite of Namaqualand and Bushmanland, South Africa, S. Afr. J. Geol., 88(2), 281-294.

Moore, A., T. Blenkinsop, and F. W. Cotterill (2008), Controls on post-Gondwana alkaline volcanism in Southern Africa, Earth Planet. Sci. Lett. 268(1), 151-164, doi:10.1016/j.epsl.2008.01.007.

Moore, A., T. Blenkinsop, and F. W. Cotterill (2009), Southern African topography and erosion history: Plumes or plate tectonics?, Terra Nova, 21(4), 310-315, doi:10.1111/j.1365-3121.2009.00887.x.

Moucha, R., and A. M. Forte (2011), Changes in African topography driven by mantle convection, Nat. Geosci., 4(10), 707-712, doi:10.1038/ ngeo1235.

Moucha, R., A. M. Forte, J. X. Mitrovica, D. B. Rowley, S. Quéré, N. A. Simmons, and S. P. Grand (2008), Dynamic topography and long-term sealevel variations: There is no such thing as a stable continental platform, Earth Planet. Sci. Lett., 271(1), 101-108, doi:10.1016/j. epsl.2008.03.056

Moulin, M., D. Aslanian, and P. Unternehr (2010), A new starting point for the South and Equatorial Atlantic Ocean, Earth Sci. Rev., 98(1), 1-37, doi:10.1016/j.earscirev.2009.08.001

Moulin, M., F. Fluteau, V. Courtillot, J. Marsh, G. Delpech, X. Quidelleur, M. Gerard, and A. E. Jay (2011), An attempt to constrain the age, duration, and eruptive history of the Karoo flood basalt: Naude's Nek section (South Africa), J. Geophys. Res., 116, B07403, doi:10.1029/2011JB008210.

Müller, R. D., M. Sdrolias, C. Gaina, and W. R. Roest (2008), Age, spreading rates, and spreading asymmetry of the world's ocean crust, Geochem. Geophys. Geosyst., 9, Q04006, doi:10.1029/2007GC001743.

Mvondo, F., O. Dauteuil, and F. Guillocheau (2011), The Fish River Canyon (Southern Namibia): A record of Cenozoic mantle dynamics?, C. $R$. Geosci., 343(7), 478-485, doi:10.1016/j.crte.2011.07.003.

Nürnberg, D., and R. D. Müller (1991), The tectonic evolution of the South Atlantic from Late Jurassic to present, Tectonophysics, 191(1), 27-53, doi:10.1016/0040-1951(91)90231-g

Nyblade, A. A., and S. W. Robinson (1994), The African superswell, Geophy. Res. Lett., 21, 765-768, doi:10.1029/94GL00631.

Ollier, C. D., and M. E. Marker (1985), The Great Escarpment of Southern Africa, Z. Geomorph. Suppl., 54, 37-56.

Partridge, T. C., and R. R. Maud (1987), Geomorphic evolution of southern Africa since the Mesozoic, S. Afr. J. Geol., 90(2), 179-208

Paul, J. D., G. G. Roberts, and N. White (2014), The African landscape through space and time, Tectonics, 33, 898-935, doi:10.1002/ 2013 TC003479.

Pérez-Díaz, L., and G. Eagles (2014), Constraining South Atlantic growth with seafloor spreading data, Tectonics, 33, 1848-1873, doi:10.1002/ 2014 TC003644.

Pérez-Gussinyé, M., and A. B. Watts (2005), The long-term strength of Europe and its implications for plate-forming processes, Nature, 436(7049), 381-384, doi:10.1038/nature03854.

Persano, C., F. M. Stuart, P. Bishop, and T. J. Dempster (2005), Deciphering continental breakup in eastern Australia using low-temperature thermochronometers, J. Geophys. Res., 110, B12405, doi:10.1029/2004JB003325

Pickford, M., and B. Senut (1997), Cainozoic mammals from coastal Namaqualand, South Africa, Palaeontol. Afr., 34, $199-217$.

Raab, M. J., R. W. Brown, K. Gallagher, A. Carter, and K. Weber (2002), Late Cretaceous reactivation of major crustal shear zones in northern Namibia: Constraints from apatite fission track analysis, Tectonophysics, 349(1), 75-92, doi:10.1016/s0040-1951(02)00047-1.

Raab, M. J., R. W. Brown, K. Gallagher, K. Weber, and A. J. W. Gleadow (2005), Denudational and thermal history of the Early Cretaceous Brandberg and Okenyenya igneous complexes on Namibia's Atlantic passive margin, Tectonics, 24, TC3006, doi:10.1029/2004TC001688

Redfield, T. F., and P. T. Osmundsen (2014), Some remarks on the earthquakes of Fennoscandia: A conceptual seismological model drawn from the perspective of hyperextension, Norw. J. Geol./Norsk Geologisk Forening, 94(4), 233-262.

Reiners, P. W., and K. A. Farley (2001), Influence of crystal size on apatite (U-Th)/He thermochronology: An example from the Bighorn Mountains, Wyoming, Earth Planet. Sci. Lett., 188(3), 413-420, doi:10.1016/s0012-821x(01)00341-7.

Roberts, D. L., et al. (2011), Regional and global context of the Late Cenozoic Langebaanweg (LBW) palaeontological site: West Coast of South Africa, Earth Sci. Rev., 106(3), 191-214, doi:10.1016/j.earscirev.2011.02.002. 
Roberts, G. G., and N. White (2010), Estimating uplift rate histories from river profiles using African examples, J. Geophys. Res., 115, B02406, doi:10.1029/2009JB006692.

Rosendahl, B. R. (1987), Architecture of continental rifts with special reference to East Africa, Ann. Rev. Earth Planet. Sci., 15, 445-503, doi:10.1146/annurev.ea.15.050187.002305.

Rouby, D., S. Bonnet, F. Guillocheau, K. Gallagher, C. Robin, F. Biancotto, O. Dauteuil, and J. Braun (2009), Sediment supply to the Orange sedimentary system over the last 150 My: An evaluation from sedimentation/denudation balance, Mar. Pet. Geol., 26(6), 782-794, doi:10.1016/j.marpetgeo.2008.08.004.

Rudge, J. F., G. G. Roberts, N. White, and C. N. Richardson (2015), Uplift histories of Africa and Australia from linear inverse modeling of drainage inventories, J. Geophys. Res. Earth Surf., 120, 894-914, doi:10.1002/2014JF003297.

Salomon, E., D. Koehn, C. Passchier, P. C. Hackspacher, and U. A. Glasmacher (2014), Contrasting stress fields on correlating margins of the South Atlantic, Gondwana Res., 28(3), 1152-1167, doi:10.1016/j.gr.2014.09.006.

Salomon, E., D. Koehn, and C. Passchier (2015), Brittle reactivation of ductile shear zones in NW Namibia in relation to South Atlantic rifting, Tectonics, 34, 70-85, doi:10.1002/2014TC003728.

Scharf, T. E., A. T. Codilean, M. de Wit, J. D. Jansen, and P. W. Kubik (2013), Strong rocks sustain ancient postorogenic topography in southern Africa, Geology, 41(3), 331-334, doi:10.1130/g33806.1.

Shuster, D. L., R. M. Flowers, and K. A. Farley (2006), The influence of natural radiation damage on helium diffusion kinetics in apatite, Earth Planet. Sci. Lett., 249(3), 148-161, doi:10.1016/j.epsl.2006.07.028.

Smith, C. B., T. C. Clark, E. S. Barton, and J. W. Bristow (1994), Emplacement ages of kimberlite occurrences in the Prieska region, southwest border of the Kaapvaal Craton, South Africa, Chem. Geol., 113(1), 149-169.

Smith, R. M. H. (1986), Sedimentation and palaeoenvironments of Late Cretaceous crater-lake deposits in Bushmanland, South Africa, Sedimentology, 33(3), 369-386, doi:10.1111/j.1365-3091.1986.tb00542.x.

Sobel, E. R., and D. Seward (2010), Influence of etching conditions on apatite fission-track etch pit diameter, Chem. Geol., 271(1), 59-69, doi:10.1016/j.chemgeo.2009.12.012.

Sodoudi, F., X. Yuan, R. Kind, S. Lebedev, J. M. C. Adam, E. Kästle, and F. Tilmann (2013), Seismic evidence for stratification in composition and anisotropic fabric within the thick lithosphere of Kalahari Craton, Geochem. Geophys. Geosyst., 14, 5393-5412, doi:10.1002/2013GC004955

Spiegel, C., B. Kohn, D. Belton, Z. Berner, and A. Gleadow (2009), Apatite (U-Th-Sm)/He thermochronology of rapidly cooled samples: The effect of He implantation, Earth Planet. Sci. Lett., 285(1), 105-114, doi:10.1016/j.epsl.2009.05.045.

Stanley, J. R., R. M. Flowers, and D. R. Bell (2013), Kimberlite (U-Th)/He dating links surface erosion with lithospheric heating, thinning, and metasomatism in the southern African Plateau, Geology, 41(12), 1243-1246, doi:10.1130/g34797.1.

Stanley, J. R., R. M. Flowers, and D. R. Bell (2015), Erosion patterns and mantle sources of topographic change across the southern African Plateau derived from the shallow and deep records of kimberlites, Geochem. Geophys. Geosyst., 16, 3235-3256, doi:10.1002/2015GC005969.

Stevenson, I. R., and I. K. McMillan (2004), Incised valley fill stratigraphy of the Upper Cretaceous succession, proximal Orange Basin, Atlantic margin of Southern Africa, J. Geol. Soc., 161(2), 185-208, doi:10.1144/0016-764902-003.

Stollhofen, H., S. Gerschütz, I. G. Stanistreet, and V. Lorenz (1998), Tectonic and volcanic controls on Early Jurassic rift-valley lake deposition during emplacement of Karoo flood basalts, southern Namibia, Palaeogeogr. Palaeoclimatol. Palaeoecol., 140(1), 185-215, doi:10.1016/ S0031-0182(98)00029-7.

Summerfield, M. A. (1985), Plate tectonics and landscape development on the African continent, in Tectonic Geomorphology, edited by M. Morisawa and J. T. Hack, pp. 27-51, Allan and Unwin, Boston, Mass.

Svensen, H., F. Corfu, S. Polteau, Ø. Hammer, and S. Planke (2012), Rapid magma emplacement in the Karoo large igneous province, Earth Planet. Sci. Lett., 325, 1-9, doi:10.1016/j.epsl.2012.01.015.

Tankard, A., H. Welsink, P. Aukes, R. Newton, and E. Stettler (2009), Tectonic evolution of the Cape and Karoo basins of South Africa, Mar. Pet Geol., 26(8), 1379-1412, doi:10.1016/j.marpetgeo.2009.01.022.

Thomas, D. S. G., and P. A. Shaw (1990), The deposition and development of the Kalahari Group sediments, Central Southern Africa, J. Afr. Earth Sci. (and the Middle East), 10(1-2), 187-197, doi:10.1016/0899-5362(90)90054-I.

Thomas, R. J., A. L. D. Agenbacht, D. H. Cornell, and J. M. Moore (1994), The Kibaran of southern Africa: Tectonic evolution and metallogeny, Ore Geol. Rev., 9(2), 131-160, doi:10.1016/0169-1368(94)90025-6.

Tinker, J., M. de Wit, and R. Brown (2008), Linking source and sink: Evaluating the balance between onshore erosion and offshore sediment accumulation since Gondwana break-up, South Africa, Tectonophysics, 455(1), 94-103, doi:10.1016/j.tecto.2007.11.040.

Tooth, S., and T. S. McCarthy (2004), Anabranching in mixed bedrock-alluvial rivers: The example of the Orange River above Augrabies Falls, Northern Cape Province, South Africa, Geomorphology, 57(3), 235-262, doi:10.1016/S0169-555X(03)00105-3.

Torsvik, T. H., S. Rousse, C. Labails, and M. A. Smethurst (2009), A new scheme for the opening of the South Atlantic Ocean and the dissection of an Aptian salt basin, Geophys. J. Int., 177(3), 1315-1333, doi:10.1111/j.1365-246X.2009.04137.x.

Torsvik, T. H., K. Burke, B. Steinberger, S. J. Webb, and L. D. Ashwal (2010), Diamonds sampled by plumes from the core-mantle boundary, Nature, 466(7304), 352-35, doi:10.1038/nature09216.

van der Beek, P., M. A. Summerfield, J. Braun, R. W. Brown, and A. Fleming (2002), Modeling postbreakup landscape development and denudational history across the southeast African (Drakensberg Escarpment) margin, J. Geophys. Res., 107(B12), 2351, doi:10.1029/2001 JB000744

van der Wateren, F. M., and T. J. Dunai (2001), Late Neogene passive margin denudation history-Cosmogenic isotope measurements from the central Namib desert, Global Planet. Change, 30(3), 271-307, doi:10.1016/s0921-8181(01)00104-7.

Vermeesch, P. (2009), RadialPlotter: A Java application for fission track, luminescence and other radial plots, Radiat. Meas., 44(4), 409-410.

Vermeesch, P., and Y. Tian (2014), Thermal history modelling: HeFTy vs. QTQt, Earth Sci. Rev., 139, 279-290, doi:10.1016/j. earscirev.2014.09.010.

Viola, G., M. Andreoli, Z. Ben-Avraham, I. Stengel, and M. Reshef (2005), Offshore mud volcanoes and onland faulting in southwestern Africa: Neotectonic implications and constraints on the regional stress field, Earth Planet. Sci. Lett., 231(1), 147-160, doi:10.1016/j. epsl.2004.12.001.

Viola, G., A. Kounov, M. A. G. Andreoli, and J. Mattila (2012), Brittle tectonic evolution along the western margin of South Africa: More than 500 Myr of continued reactivation, Tectonophysics, 514, 93-114, doi:10.1016/j.tecto.2011.10.009.

Visser, J. N. J. (1989), The Permo-Carboniferous Dwyka Formation of southern Africa: Deposition by a predominantly subpolar marine ice sheet, Palaeogeogr. Palaeoclimatol. Palaeoecol., 70(4), 377-391, doi:10.1016/0031-0182(89)90115-6.

Wang, H., J. van Hunen, D. G. Pearson, and M. B. Allen (2014), Craton stability and longevity: The roles of composition-dependent rheology and buoyancy, Earth Planet. Sci. Lett., 391, 224-233, doi:10.1016/j.epsl.2014.01.038.

Ward, J. D., and H. Martin (1987), A terrestrial conglomerate of Cretaceous age-A new record from the Skeleton Coast, Namib Desert, Commun. Geol. Surv. South West Afr./Namibia, 3, 57-58. 
Waters, D. J. (1989), Metamorphic evidence for the heating and cooling path of Namaqualand granulites, Geol. Soc. London, Spec. Publ., 43(1), 357-363, doi:10.1144/gsl.sp.1989.043.01.31.

Wildman, M., R. Brown, R. Watkins, A. Carter, A. Gleadow, and M. Summerfield (2015), Post break-up tectonic inversion across the southwestern cape of South Africa: New insights from apatite and zircon fission track thermochronometry, Tectonophysics, 654, 30-55, doi:10.1016/j.tecto.2015.04.012.

Wildman, M., R. Brown, R. Beucher, C. Persano, F. Stuart, K. Gallagher, J. Schwanethal, and A. Carter (2016), The chronology and tectonic style of landscape evolution along the elevated Atlantic continental margin of South Africa resolved by joint apatite fission track and (U-Th$\mathrm{Sm}) / \mathrm{He}$ thermochronology, Tectonics, 35, 511-545, doi:10.1002/2015TC004042.

Wilson, A., S. Flint, T. Payenberg, E. Tohver, and L. Lanci (2014), Architectural styles and sedimentology of the fluvial lower Beaufort Group, Karoo Basin, South Africa, J. Sediment. Res., 84(4), 326-348, doi:10.2110/jsr.2014.28.

Youssof, M., H. Thybo, I. M. Artemieva, and A. Levander (2013), Moho depth and crustal composition in Southern Africa, Tectonophysics, 609 267-287, doi:10.1016/j.tecto.2013.09.001.

Youssof, M., H. Thybo, I. M. Artemieva, and A. Levander (2015), Upper mantle structure beneath southern African cratons from seismic finitefrequency P-and S-body wave tomography, Earth Planet. Sci. Lett., 420, 174-186, doi:doi:10.1016/j.epsl.2015.01.034

Zachos, J., M. Pagani, L. Sloan, E. Thomas, and K. Billups (2001), Trends, rhythms, and aberrations in global climate 65 Ma to present, Science, 292(5517), 686-693, doi:10.1126/science.1059412. 